\title{
The Impact of Primary Marine Aerosol on Atmospheric Chemistry, Radiation and Climate: A CCSM Model Development Study
}

Applicant/Institution:

Address:

Principal Investigator:

Address:

Telephone Number:

E-mail:

DOE/Office of Science Program Office:
University of Virginia

Dept. of Environmental Sciences

Clark Hall

291 McCormick Rd

PO Box 400123

Charlottesville, VA 22904-4123

William C. Keene

Dept. of Environmental Sciences

Clark Hall

291 McCormick Rd

PO Box 400123

University of Virginia

Charlottesville, VA 22904-4123

(434) 924-0586

wck@virginia.edu

Biological \& Environmental Research 
Abstract: This project examined the potential large-scale influence of marine aerosol cycling on atmospheric chemistry, physics and radiative transfer. Measurements indicate that the sizedependent generation of marine aerosols by wind waves at the ocean surface and the subsequent production and cycling of halogen-radicals are important but poorly constrained processes that influence climate regionally and globally. A reliable capacity to examine the role of marine aerosol in the global-scale atmospheric system requires that the important size-resolved chemical processes be treated explicitly. But the treatment of multiphase chemistry across the breadth of chemical scenarios encountered throughout the atmosphere is sensitive to the initial conditions and the precision of the solution method. This study examined this sensitivity, constrained it using high-resolution laboratory and field measurements, and deployed it in a coupled chemicalmicrophysical 3-D atmosphere model. First, laboratory measurements of fresh, unreacted marine aerosol were used to formulate a sea-state based marine aerosol source parameterization that captured the initial organic, inorganic, and physical conditions of the aerosol population. Second, a multiphase chemical mechanism, solved using the Max Planck Institute for Chemistry's MECCA (Module Efficiently Calculating the Chemistry of the Atmosphere) system, was benchmarked across a broad set of observed chemical and physical conditions in the marine atmosphere. Using these results, the mechanism was systematically reduced to maximize computational speed. Finally, the mechanism was coupled to the 3 -mode modal aerosol version of the NCAR Community Atmosphere Model (CAM v3.6.33). Decadal-scale simulations with CAM v.3.6.33, were run both with and without reactive-halogen chemistry and with and without explicit treatment of particulate organic carbon in the marine aerosol source function. Simulated results were interpreted (1) to evaluate influences of marine aerosol production on the microphysical properties of aerosol populations and clouds over the ocean and the corresponding direct and indirect effects on radiative transfer; (2) atmospheric burdens of reactive halogen species and their impacts on $\mathrm{O}_{3}, \mathrm{NO}_{\mathrm{x}}, \mathrm{OH}$, DMS, and particulate non-sea-salt $\mathrm{SO}_{4}{ }^{2-}$; and (3) the global production and influences of marine-derived particulate organic carbon. The model reproduced major characteristics of the marine aerosol system and demonstrated the potential sensitivity of global, decadal-scale climate metrics to multiphase marine-derived components of Earth's troposphere. Due to the combined computational burden of the coupled system, the currently available computational resources were the limiting factor preventing the adequate statistical analysis of the overall impact that multiphase chemistry might have on climate-scale radiative transfer and climate.

This document is organized into two parts representing two project phases: (1) System development \& testing, and (2) model results. 
1 Part 1: Implementation of the chemistry module MECCA (v2.5) in the modal aerosol version of

2 the Community Atmosphere Model component (v3.6.33) of the Community Earth System Model

$4 \quad$ M.S. Long (mlong@ seas.harvard.edu)

5 School of Engineering and Applied Sciences, Harvard University, Cambridge, MA, USA

$6 \quad$ W.C. Keene (wck@ virginia.edu)

7 Department of Environmental Sciences, University of Virginia, Charlottesville, VA

8 22904, USA

9 R. Easter (Richard.Easter@pnnl.gov)

10 Atmospheric Sciences and Global Change Division, Pacific Northwest National

11 Laboratory

12 R. Sander (rolf.sander@mpic.de)

13 Air Chemistry Department, Max-Planck Institute of Chemistry, 55020 Mainz, Germany

14 A. Kerkweg (astrid.kerkweg@uni-mainz.de)

15 Institute for Atmospheric Physics, University of Mainz, 55099 Mainz, Germany

16 D. Erickson (ericksondj@ornl.gov)

17 Computer Science and Mathematics Division, Oak Ridge National Laboratory,

18 Oak Ridge, TN USA

19 X. Liu (xiaohong.liu@pnnl.gov)

20 Atmospheric Science and Global Change Division, Pacific Northwest National

21 Laboratory,

22 Richland, Washington, USA

23 S. Ghan (Steve.Ghan@pnnl.gov)

24 Atmospheric Science and Global Change Division, Pacific Northwest National

25 Laboratory,

26 Richland, Washington, USA

27 
Abstract

29 A coupled atmospheric chemistry and climate system model was developed using the modal

30 aerosol version of the National Center for Atmospheric Research Community Atmosphere

31 Model (modal-CAM; v3.6.33) and the Max Planck Institute for Chemistry's Module Efficiently

32 Calculating the Chemistry of the Atmosphere (MECCA; v2.5) to provide enhanced resolution of

33 multiphase processes, particularly those involving inorganic halogens, and associated impacts on

34 atmospheric composition and climate. Three Rosenbrock solvers (Ros-2, Ros-3, RODAS-3)

35 were tested in conjunction with the basic load balancing options available to modal CAM (1) to

36 establish an optimal configuration of the implicitly-solved multiphase chemistry module that

37 maximizes both computational speed and repeatability of Ros-2 and RODAS-3 results versus

38 Ros-3, and (2) to identify potential implementation strategies for future versions of this and

39 similar coupled systems. RODAS-3 was faster than Ros-2 and Ros-3 with good reproduction of

40 Ros-3 results, while Ros-2 was both slower and substantially less reproducible relative to Ros-3

41 results. Modal-CAM with MECCA chemistry was a factor of 15 slower than modal-CAM using

42 standard chemistry. MECCA chemistry integration times demonstrated a systematic frequency

43 distribution for all three solvers, and revealed that the change in run-time performance was due

44 to a change in the frequency distribution chemical integration times; the peak frequency was

45 similar for all solvers. This suggests that efficient chemistry-focused load-balancing schemes can

46 be developed that rely on the parameters of this frequency distribution. 
48 The spatial and temporal resolutions of geophysical modeling systems are increasing rapidly. As

49 a result, the need to more explicitly resolve many of the physical and chemical processes that

50 previously operated below the resolution and within the uncertainty ranges of these modeling

51 systems is increasing accordingly. Individually, the computational skill of physical and chemical

52 systems is high; but the computational needs of these systems in combination with dynamical

53 and geophysical models has made coupled investigations prohibitive. The capabilities of current

54 high-performance computing platforms available to geoscientific modeling are beginning to

55 permit the coupling of these systems for scientific research. Of particular interest are the

56 interactions between atmospheric chemistry and climate, particularly with respect to the

57 implications of multiphase processes for tropospheric composition, clouds, precipitation, and

58 radiative transfer.

59 Multiphase interactions, primarily between gases, aerosols and cloud droplets, represent a

60 highly non-linear set of processes that significantly impact the processing and lifetimes of many

61 important tropospheric species. Of increasing interest are chemical transformations involving

62 inorganic, halogenated $(\mathrm{Cl}$ and $\mathrm{Br})$ compounds and associated influences on the cycling of $\mathrm{NO}_{\mathrm{x}}$,

$63 \mathrm{HO}_{\mathrm{x}}, \mathrm{S}, \mathrm{O}_{3}, \mathrm{CH}_{4}$ and non-methane hydrocarbons (NMHC's), $\mathrm{Hg}$, and other species of both

64 natural and anthropogenic origin.

65 Accurately resolving interactions that control multiphase processes requires they be evaluated

66 explicitly. The computationally difficult solution of the stiff system of ordinary differential

67 equations (ODEs) derives from multiphase processes (e.g. mass transfer). Computational speed

68 must be optimized in order to execute simulations of sufficient duration to provide time for

69 model equilibration (spin-up) and generation of a sufficient sample size for analysis.

70 This manuscript describes a coupled atmospheric chemistry and climate modeling system that

71 leverages an efficient multiphase atmospheric chemistry mechanism, MECCA (Module

72 Efficiently Calculating the Chemistry of the Atmosphere; version 2.5; Sander et al., 2005, 2011)

73 within a 3-mode size-resolving aerosol module (Modal Aerosol Module) version of the National

74 Center for Atmospheric Research's (NCAR) Community Atmosphere Model (version 3.6.33;

75 Gent et al., 2009; Liu et al., 2011; hereafter referred to as modal-CAM). The modal aerosol

76 module in CAM was developed to provide a size-resolving aerosol microphysics capability

77 capable of more accurately resolving the direct and indirect impacts of aerosols on climate. 
Modal-CAM is embedded as the atmosphere component of the NCAR Community Climate

79 System Model (CCSM3.0; Collins et al, 2006). (Note: Since completion of the work presented here, CCSM has been renamed the Community Earth System Model, CESM).

The coupled modeling system used in this study was designed to investigate the role of aqueous processes and inorganic halogen cycling through use of their explicit representation in

83 MECCA combined with the size-resolving modal aerosol physics and atmospheric coupling of

84 modal-CAM. Results will be validated and interpreted in detail in a forthcoming manuscript

85 (Long, M. S., Keene, W.C., Easter, R., Sander, R., Kerkweg, A., Lui, X, Erickson, D.J, Ghan, S.,

86 Sensitivity of tropospheric chemical composition to halogen-radical chemistry using a fully

87 coupled GCM/size-resolved multiphase chemical system I: Halogen distributions, aerosol

88 composition, and sensitivity of climate-relevant gases).

\section{MECCA Model Description}

MECCA version 2.5 is a FORTRAN90 compliant atmospheric chemistry module developed to deploy easily as a submodel within base models using the MESSy interface (Modular Earth Submodel System; see http://www.messy-interface.org). Since CAM is not designed as a MESSy compliant base-model, the interface used for this study was designed from scratch to accommodate the complexities of the non-compliant GCM and the needs of the modal aerosol module. MECCA is available at no cost, under the terms of the GNU General Public License (GPL), included within - and not to be confused with - the stand-alone box-model CAABA (Chemistry As A Box-model Application).

MECCA contains a comprehensive atmospheric reaction mechanism that includes transformations involving $\mathrm{O}_{3}, \mathrm{CH}_{4}, \mathrm{HO}_{\mathrm{x}}$, and $\mathrm{NO}_{\mathrm{x}}, \mathrm{NMHCs}$, halogens $(\mathrm{Cl}, \mathrm{Br}, \mathrm{I})$, and sulfur. In addition to gas-phase reactions, the scheme includes fully integrated multiphase transformations

102 (both aqueous-phase and heterogeneous pathways) involving aerosols and cloud droplets. Mass 103 transfer is calculated dynamically per Schwartz (1986). Photochemical reaction rates vary as a 104 function of solar zenith angle under clear-sky and cloudy conditions based on Landgraf and 105 Crutzen (1998). MECCA is a MESSy-compliant sub-model within the ECHAM5/MESSy for 106 Atmospheric Chemistry (EMAC) chemistry climate GCM (CCM). Numerous investigations 107 have been performed using this system: These include evaluation of gas-phase chemistry from 108 the surface to the mesosphere (Jöckel et al. 2006), multiphase cycling of marine-derived 
109 halogens (Kerkweg et al. 2008a,b), isotopic composition of the atmosphere (Gromov et al., 110 2010), and influences of chemical processes on polar stratospheric clouds (Kirner et al., 2011).

111 A full list of EMAC applications can be found on http://messy-interface.org. See supplemental

112 Table S1 and Sander et al. (2011) for a complete description of the chemical scheme.

113 MECCA uses the Kinetics PreProcessor (KPP, Sandu and Sander, 2006) to build a solution

114 based on a choice of several predefined numerical methods. KPP was designed to facilitate

115 programming fast and accurate solutions to chemical reaction mechanisms based on user-defined

116 implicit solvers and solver configurations. It relies on sparse linear algebra routines to optimize

117 serial computational performance, and is therefore well suited for atmospheric chemistry

118 problems over a wide range of complexities.

119 The tropospheric chemical mechanism used in the coupled model was based on a subset of the

120 full MECCA mechanism. Other than the addition of gas-phase reactions for non-methane

121 hydrocarbons (NMHCs; based on von Kuhlmann et al. (2003)), the mechanism was identical to

122 that used in Keene et al. (2009) although configured for three rather than eight aerosol size bins.

123 Photochemical rates were calculated using MECCA's JVAL submodel.

\section{Modal-CAM Atmosphere Model}

126 Atmospheric processes were simulated in three dimensions (3-D) using CAM at $1.9^{\circ} \times 2.5^{\circ}$ lat-

127 long resolution with 26 vertical levels (Gent et al., 2009). CAM is a FORTRAN90 compliant

128 general circulation system built upon an extensive set of high-performance computational

129 routines to preserve scalability and performance of the model across changes in resolution and

130 model physics. The high-performance structure relies upon a message passing interface (MPI),

131 or, at the user's discretion, a combination of MPI and shared-memory process routines.

132 The dynamical core (approximation of the equations of motion on a discrete, spherical grid) is

133 based on a flux-form semi-Lagrangian method (see Lin and Rood, 1996) that is better suited for

134 tracer transport. This approach permits grid-wide stability of the chemistry solution, in contrast

135 to discrete methods that introduce large dispersion and diffusion errors in their approximation of

136 the equations of motion which propagate into and destabilize the chemistry solver.

137 Modal-CAM incorporates a comprehensive set of processes that control the evolution and 138 coupling of three fixed-width log-normally distributed aerosol modes (Aitken, accumulation and 139 coarse). The modal aerosol treatment is described in detail in Liu et al. (2011). Each mode 
140 consists of internally mixed populations of non-sea-salt (nss) $\mathrm{SO}_{4}{ }^{2-}$, organic matter from primary 141 sources (OM), secondary organic aerosol (SOA) from volatile organic precursors, black carbon

142 (BC), inorganic sea salt, and mineral dust. The nss- $\mathrm{SO}_{4}{ }^{2-}$ is assumed to be in the form of

$143 \mathrm{NH}_{4} \mathrm{HSO}_{4}$. OM and $\mathrm{BC}$ are treated only in the accumulation mode. SOA is only in the Aitken

144 and accumulation modes, and mineral dust is only in the accumulation and coarse modes.

145 Aerosol number and aerosol water are also calculated for each mode. Aerosol mass and number

146 associated with stratiform cloud droplets are treated explicitly.

147 The following processes affect aerosols in the model: Grid-resolved transport, sub-grid vertical 148 transport by turbulence and convective clouds, emissions (surface and elevated), sedimentation 149 and dry deposition, cloud droplet activation and subsequent aerosol resuspension, wet removal

150 (in- and below-cloud by stratiform and convective clouds), condensation of $\mathrm{H}_{2} \mathrm{SO}_{4}(\mathrm{~g})$ and 151 condensation/evaporation of semi-volatile organics and water, cloud chemistry (oxidation of $\mathrm{SO}_{2}$ 152 to $\mathrm{H}_{2} \mathrm{SO}_{4}$ ), transfer (renaming) of particles from Aitken to accumulation mode due to growth via 153 condensation and cloud chemistry, aerosol nucleation, and aerosol coagulation (Aitken and 154 accumulation modes only). Trace gas processes include transport, emission, and dry and wet 155 deposition.

156

\section{MECCA/Modal-CAM Coupling}

158 The coupling involves (1) adding MECCA chemical species to CAM, (2) interfacing MECCA 159 gas, aerosol and cloud chemistry routines within CAM (and disabling the corresponding CAM 160 routines), and (3) as needed, modifying CAM routines for processes that affect MECCA and 161 modal-CAM species (e.g. emission of sea-salt species). This initial implementation is not a 162 complete two-way coupling between MECCA and modal-CAM, as indicated in Fig. 1, since 163 some MECCA aerosol species do not interact directly with the modal-CAM physics. This was 164 done to minimize unnecessary modifications to processes that have little impact from one system 165 to another. The impact of this configuration on memory use and model performance was not 166 evaluated.

167 The MECCA gas and aqueous aerosol species were added to the existing fully-transported 168 trace species in CAM: 96 gas species ( 4 of which were already treated in modal-CAM), and 31 169 aqueous aerosol species in each of the 3 size modes. The MECCA aqueous cloud-droplet 170 species (31 species for each mode) were also added to the modal-CAM cloud-borne species, 
171 which are not fully transported (Liu et al., 2012). This coupling interfaces the bulk inorganic

172 aerosol composition considered by microphysical routines in modal-CAM with chemical

173 speciation evaluated for multiphase processes in MECCA. As such, the system uses redundant

174 chemical species to account for $\mathrm{nss}_{-} \mathrm{SO}_{4}{ }^{2-}$ and seasalt between two tracer arrays. Gas-phase

175 species are shared between the MECCA and modal-CAM tracer arrays. Since it was necessary to 176 ensure that the impact of model routines on both bulk species in modal-CAM (e.g. $\mathrm{NaCl}$ ), and

177 corresponding speciation in MECCA (e.g. $\mathrm{Na}^{+}$and $\mathrm{Cl}^{-}$) are proportional, several model routines

178 operate on both tracer arrays simultaneously (see Fig. 1). Modal-CAM stores information about

179 both sets of species throughout a time-step, and changes are updated accordingly - either from

180 MECCA to CAM (Fig. 1, step 6) or CAM to MECCA (Fig. 1, step 8). The iteration of one model 181 time-step as outlined in Fig. 1 involved 10 discrete steps:

182 Step 1: This step calculates the advective transport for all chemical species.

183 Step 2: Vertical transport of gases and interstitial aerosols in both tracer arrays by shallow

184 convective clouds is calculated. Aerosol activation/resuspension in stratiform clouds is then

185 calculated in conjunction with turbulent vertical mixing, acting on both tracer arrays. The

186 aerosol activation utilizes the modal-CAM aerosol composition (e.g. hygroscopicity

187 calculation neglects MECCA chemical species); but tendencies are applied to all aerosol

$188 \quad$ species.

189 Step 3: Aerosol water uptake is calculated based on modal-CAM's aerosol composition.

190 Resulting aerosol water content is applied to both tracer arrays. Wet deposition of all aerosol species (interstitial and cloud-borne in both arrays) through in-cloud and below-cloud

193 deep convective clouds is calculated.

194 Step 4: Below-cloud scavenging by rainwater of all soluble gases occurs here.

195 Step 5: Gas, aerosol, and photo chemistry act only on the MECCA tracer array (see Section 2).

196 Total overhead stratospheric $\mathrm{O}_{3}$ necessary for photochemical rate calculations in MECCA's

197 JVAL routine was prescribed. Ion balance is maintained in MECCA by adjusting an inert 198 dummy cation tracer representing the combined charges of $\mathrm{Na}^{+}, \mathrm{Ca}^{+}$, and $\mathrm{Mg}^{+}$, which was 199 not coupled to modal-CAM NaCl mass. With the exception of that involving SOA, all gas200 aerosol exchange was calculated by MECCA. 
Step 6: Cloud chemistry includes MECCA-only gas/cloudwater exchange of soluble gas species, equilibrium, and aqueous chemistry in cloud droplets. Cloud chemistry was only activated above a grid-box cloud-fraction threshold of $1 \times 10^{-5}$.

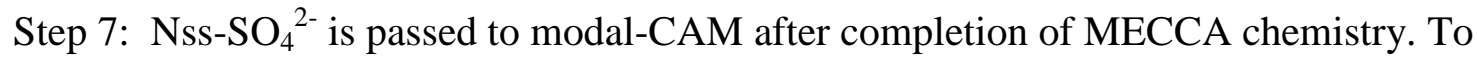
differentiate total $\mathrm{SO}_{4}{ }^{2-}$ in MECCA, which includes sea-salt $\mathrm{SO}_{4}{ }^{2-}$ from nss- $\mathrm{SO}_{4}{ }^{2-}$ in modal $\mathrm{CAM}$, only the net change in nss-SO ${ }_{4}{ }^{2-}$ due to MECCA aerosol chemistry $\left(\triangle \mathrm{SO}_{4, \text { Chemistry }}\right.$ from aqueous reaction and $\mathrm{H}_{2} \mathrm{SO}_{4}$ vapor uptake) was considered where

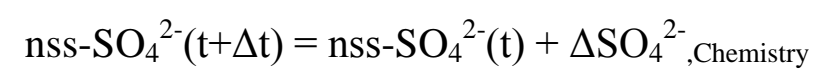

Nss-SO ${ }_{4}{ }^{2-}$, as passed to modal-CAM, is the sum of MECCA's $\mathrm{H}_{2} \mathrm{SO}_{4}(\mathrm{aq}), \mathrm{HSO}_{4}{ }_{4}^{-}$, and $\mathrm{SO}_{4}{ }^{2-}$ species calculated from eq. (1). Nss- $\mathrm{SO}_{4}{ }^{2-}$ for each mode, $\mathrm{H}_{2} \mathrm{SO}_{4}$ vapor, and corresponding net changes per time-step were calculated here for use by the modal-CAM microphysical routines (step 8 ).

Step 8: The aerosol microphysical processes of condensation (SOA only), intermodal transfer (renaming) after particle growth, nucleation, and coagulation are calculated in modal-CAM routines. Intermodal transfer and coagulation are now applied to both modal-CAM and MECCA aerosol species. Since mass-transfer from the gas to aqueous phase is included in the MECCA chemical ODE, modal-CAM gas-aerosol exchange and condensation routines are switched off for all species except for SOA.

Step 9: The only net source of nss- $\mathrm{SO}_{4}{ }^{2-}$ in step 8 was through nucleation of $\mathrm{H}_{2} \mathrm{SO}_{4}(\mathrm{~g})$. This increase in nss- $\mathrm{SO}_{4}{ }^{2-}$ due to modal aerosol processing was passed to MECCA as addition of $\mathrm{H}_{2} \mathrm{SO}_{4}$ (aq) to the Aitken mode. In this configuration, both total nss- $\mathrm{SO}_{4}{ }^{2-}$ and $\mathrm{H}^{+}$are conserved.

Step 10: Emissions of gases, and black carbon, primary organic matter, and $\mathrm{NH}_{4} \mathrm{HSO}_{4}$ aerosol are driven by offline datasets, while sea salt (and dust?) emissions are calculated online. $\mathrm{NH}_{4} \mathrm{SO}_{4}$ aerosol are emitted directly as $\mathrm{NH}_{4}{ }^{+}$and $\mathrm{HSO}_{4}{ }^{2-}$ into the MECCA tracer array. The transfer of nss- $\mathrm{SO}_{4}{ }^{2-}$ into the modal-CAM array occurs later (step 6). Sea salt aerosol is as both $\mathrm{NaCl}$ in the modal-CAM array and speciated in MECCA as $\mathrm{Na}^{+}, \mathrm{Cl}^{-}, \mathrm{SO}_{4}{ }^{2-}, \mathrm{CO}_{3}{ }^{2-}$, and $\mathrm{Br}^{-}$. Sea-salt derived $\mathrm{SO}_{4}{ }^{2-}$ is excluded from modal-CAM (see step 6). Vertical turbulent mixing is applied to all gases. (This is done in step 3 for aerosols.) Dry deposition is 
Since impacts on aerosol physical properties due to small changes in abundance of inorganic

233 aerosol species other than $\mathrm{Na}^{+}, \mathrm{NO}_{3}{ }^{-}, \mathrm{NH}_{4}{ }^{+}$and $\mathrm{SO}_{4}{ }^{2-}$ are limited, and to simplify the modal-

234 CAM aerosol size and inter-modal exchange routines, mass and density of any species specific to

235 MECCA only were not considered in calculations of particle mass and size (i.e. density of aged

236 and fresh sea salt are the same). As a result, they only interacted with particle dry diameter

237 through changes in nss- $\mathrm{SO}_{4}{ }^{2-}, \mathrm{NH}_{4}{ }^{+}$, and $\mathrm{NO}_{3}{ }^{-}$. As well, the volume-weighted hygroscopicities

238 and refractive indices of aerosol modes were calculated using modal-CAM species: bulk $\mathrm{NaCl}$,

239 nss- $\mathrm{SO}_{4}{ }^{2-}$, dust, $\mathrm{BC}, \mathrm{POM}$, and $\mathrm{SOA}$ in the 3-mode version, plus $\mathrm{NH}_{4}{ }^{+}$and $\mathrm{NO}_{3}{ }^{-}$in the 7 -mode

240 version

\section{Computational Configuration and Performance}

In a global simulation grid that includes the breadth of atmospheric chemical scenarios at any

244 one time-point in the simulation, the use of implicit methods for the multiphase chemistry

245 solution disrupts the scalability of the MPI-based parallel system. In particular, the stiffness of

246 the chemical mechanism, and thus the time and resources needed to reach a solution for a given

247 grid-box, varies geographically in the 3-D domain (e.g., see of Kerkweg et al., 2007). Proximity

248 to large sources and sinks of highly-reactive species or large gradients in physical or chemical

249 conditions complicate the implicit solution. In CAM, systematic, non-random decomposition and

250 allocation of column-subsets of the 3-D grid to the available computational processes segregates

251 a disproportionately large chemical-solution burden into a small subset of processes. Since

252 CAM's time-stepping routines rely on an MPI AllGather routine, model performance is limited

253 by the speed of the slowest column-subset. Model load-balancing optimizations (available since

254 CAM version 3.6) permit the building of MPI column-subsets and allocating them to processes

255 in ways which enhances the distribution of 'difficult' columns across available computational

256 process units (see Mirin and Worley, 2011). The option used for this study (phys_loadbalance =

257 2) builds column-subsets from north/day-south/night grid-point pairs. For example, a grid-point

258 at $45 \mathrm{deg} \mathrm{N}, 0 \mathrm{deg} \mathrm{E}$ is paired with the point at $45 \mathrm{deg} \mathrm{S}$ and $180 \mathrm{deg}$ E. Consequently, since most

259 land area is in the northern hemisphere, this procedure load-balances based across day/night,

260 season, and, to a large extent land/ocean. The set of paired points are then combined into

261 column-subsets and assigned to processes. The maximum number of column-subsets that can be

262 obtained (thus, the number of independent computational processes that can be used 
263 simultaneously) is controlled by dynamic limitations and the horizontal grid size. CAM has been 264 designed to permit allocating additional processes to solve model physics separately from the 265 dynamics routines, which allows a much faster computation of the coupled system.

266 To evaluate the computational performance of the coupled system, decomposed as described, 267 three positive-definite, adjustable-timestep Rosenbrock methods were tested for accuracy and 268 performance metrics. Sander et al. (2005) found that, for the MECCA chemical mechanism, $2^{\text {nd }}$ 269 and $3^{\text {rd }}$ order solvers performed best in terms of both stability and computational speed. Other 270 studies have investigated the stability and efficiency of the Rosenbrock solvers in KPP across a 271 range of chemical scenarios (Henze et al., 2007; Verwer et al., 1999; Sandu et al., 1997). To our 272 knowledge, this study is the first in which KPP's Rosenbrock solvers were tested against such a 273 complex chemical mechanism including gas, multiphase, and photochemistry through the entire 274 atmosphere.

275 For stability reasons, the Ros-3 (3-stage, order 3(2), L-stable) solver was employed 276 preferentially in past MECCA simulations (e.g. Keene et al., 2009). Consequently, for these 277 tests, coupled simulation results using Ros-3 are considered the benchmark against which results 278 using Ros-2 (2-stage, order 2(1), L-stable) and RODAS-3 (4-stage, order 3(2), stiffly accurate) 279 solvers are compared (see Hairer and Wanner, 1991). The coupled system was run for 5 years 280 with the Ros-3 solver to stabilize chemistry in the troposphere - defined as a net change in year281 to-year total global $\mathrm{O}_{3}$ mass of less than $1 \%$ (actual net $\mathrm{O}_{3}$ change between years 4 and 5 was $2820.16 \%$ versus $4.7 \%$ between years 3 and 4 of the equilibration period). One-month (January) 283 simulations were then executed using the three solvers. Ros-2 and RODAS-3 were compared to 284 Ros-3 for computational speed and reproducibility of several species. Absolute and relative 285 tolerances were set to $10 \mathrm{~cm}^{-3}$ and 0.01 , respectively.

286 In the implicit solution to the multiphase mechanism, the main sources of instability and 287 stiffness involved complex, fast, multiphase chemistry in the near-surface layers. In addition to 288 high liquid water contents in these layers relative to others, there were large, wind and geography 289 driven 3-D gradients in reactive species and trace intermediates due to reactions in neighboring 290 grid regions, emissions, deposition, microphysical processing, and scavenging. Thus, it is in 291 close proximity to the surface that the limitations of each numerical method - whether in 292 computational stability or accuracy of the solution - was best evaluated. 
Figure 2 compares mass mixing ratios of the one-month benchmark for $\mathrm{O}_{3}, \mathrm{OH}, \mathrm{Br}_{2}$, and 294 coarse-mode aqueous $\mathrm{H}^{+}$for all model layers between the surface and $900 \mathrm{mb}$. These species were selected to reflect climate relevance, source of stiffness, halogen cycle reproducibility, and relevant aqueous processes. Regression statistics are given in Table 1. Ros-2 is able to reproduce $\mathrm{O}_{3}$ and $\mathrm{OH}$ with reasonable confidence, whereas $\mathrm{Br}_{2}$ and to a much greater extent, $\mathrm{H}^{+}$were less precisely reproduced. The reason for the systematic over-prediction of $\mathrm{H}^{+}$by Ros- 2 is not clear, but may reflect stiffness associated with the aqueous (acid-base) reactions and mass transfer.

300 Conversely, results based on RODAS-3 were more similar to those based on Ros-3 in terms of 301 both absolute (regression slope near 1) and relative differences (higher correlation coefficient;

302 Table 1). The $\mathrm{H}^{+}$root mean square error (RMSE; normalized against mean Ros-3 mixing ratios) 303 was still high for the RODAS-3 results. The scatter at higher $\mathrm{H}^{+}$mixing ratios generally

304 corresponded to continental regions where sources of atmospheric acids are relatively greater and 305 sea-salt $\mathrm{Cl}^{-}$and associated regulation of aerosol acidity via $\mathrm{HCl}$ phase partitioning is relatively 306 less important. $\mathrm{H}^{+}$is highly sensitive to changes in chemistry and circulation in these regions. 307 Circulation changes may also be reflected in the other species due to radiative forcing by $\mathrm{O}_{3}$ over 308 the benchmark time period. The comparisons demonstrate that RODAS-3 performs markedly 309 better than Ros-2 for all four species.

310 Relative to Ros-3, completion of the one-month benchmark simulation with RODAS-3 was 9\% 311 faster and Ros-2 was $18 \%$ slower. This is in agreement with a study of KPP solvers in the 312 GEOS-Chem chemistry transport model (Henze, 2007; Eller et al., 2008), although GEOS-Chem 313 uses KPP only for gas-phase calculations and is driven by offline circulation. The frequency

314 distributions of average integration times (or waiting-time for completion of one chemistry 315 timestep) for all grid cells varied among the solvers tested (Fig. 3). Relative to RODAS-3, Ros-2 316 and, to a lesser extent, Ros-3 were skewed towards relatively longer integration times, though 317 there was no systematic change in the peak integration time frequency. These results indicate 318 that the performance gain is due primarily to reduction in frequency of large waiting times and 319 suggest that chemistry-centric grid decomposition and column subsetting that leverages this 320 frequency distribution may yield better model performance. The distribution of waiting times 321 across the global grid demonstrates a physical dependence. While not shown here, chemistry 322 waiting times are inversely dependent upon altitude - the maxima occur in the model surface 323 layer. Further, data show a weak but positive correlation to a combination of total aerosol liquid 
324 water and solar zenith angle (as a measure of photochemistry). Based on the benchmark

325 simulation intercomparison, MECCA chemistry for the fully-coupled simulations was solved 326 using the RODAS-3 solver.

327 MECCA, as the chemical operator in CAM, had a substantial impact on model runtime 328 prohibiting the use of this configuration for long-term (century-scale) simulations without a large cost in computational resources. Incorporation of the MECCA species and chemistry routines increased CAM's runtime by a factor of 15 relative to modal-CAM configured with the standard chemical module. Replacing modal-CAM's chemical module with MECCA chemistry slowed overall computational speed by a factor of 8 . The transport routines were a factor of 7 slower due

333 to an increase from 25 to 205 active tracers. Further, the data storage needs of a system this 334 extensive were large enough that considerations of Input/Output (I/O) frequency and number of 335 diagnostic quantities was necessary. Monthly-mean output from a 10-year simulation of the coupled system required nearly $850 \mathrm{~GB}$ storage, which added an additional computational burden due to the system I/O. I/O is often limiting factor in high-performance system scalability, though it was not a large factor in this system.

\section{Summary}

A coupled atmospheric chemistry and climate system model was developed to investigate the details of multiphase processes and associated impacts on chemistry and climate. The computational needs of the chemical system required that performance of individual modules be enhanced. Comparison of three implicit Rosenbrock solvers revealed substantial differences in computational performance for coupled simulations that were distinct from similar investigations based on box models alone. This is likely due to the effect of fixed versus variable physical conditions in $0-\mathrm{D}$ versus 3-D global models, combined with the impact of load balancing methods on the net system runtime (solver performance in individual gridboxes was not evaluated). Overall the RODAS-3 solver provided the best performance for the current 350 computational configuration.

351 In addition to optimizations discussed above, such as chemistry-centric load-balancing, several 352 strategies can be pursued to further increase the coupled system's performance. First, chemical 353 species with atmospheric lifetimes shorter than residence-times in a given grid box (so called 354 short-lived species such as $\left.\mathrm{O}\left({ }_{1} \mathrm{D}\right)\right)$ can be ignored by the dynamics routines. Prior to including 
MECCA into CAM for this study, the cost of including additional tracers was the largest factor impacting the system's computational burden. Second, reduction of the size of the chemical mechanism in combination with load-balancing will likely have the greatest impact on runtime. A systematic approach to determining the smallest mechanism necessary to constrain the behavior of a specific subset of chemical species (e.g. $\mathrm{O}_{3}$ and sulfur) is currently being developed using this system. Lastly, the adoption of optimized or parallel-capable linear algebra routines has the potential to significantly speed up the implicit chemistry, but we are not aware of any successful studies showing this. Doing so would require substantial changes to the existing parallelization strategy in CAM. The development of hybrid systems using stream and conventional processors provides a good opportunity to examine this approach.

MECCA, CAM, and the CESM are available for download. The code used here can be made available to users upon request.

\section{References}

Collins, W. D., Bitz, C. M., Blackmon, M. L., Bonan, G. B ., Bretherton, C. S., Carton, J. A., Chang, P., Doney, S. C., Hack, J. J., Henderson, T. B., Kiehl, J. T., Large, W. G., McKenna, D. S., Santer, B. D., and Smith, R. D.: The Community Climate System Model Version 3 (CCSM3). J. Climate, 19, 2122-2143. doi: http://dx.doi.org/10.1175/JCLI3761.1, 2006.

Eller, P., Singh, K., Sandu, A., Bowman, K., Henze, D. K., and Lee, M.: Implementation and evaluation of an array of chemical solvers in a global chemical transport model, Geosci. Model Dev. Discuss., 2, 185-207, doi:10.5194/gmdd-2-185-2009, 2009.

Gent, P. R., Yeager, S. G., Neale, R. B., Levis, S., and Bailey, D. A.: Improvements in a half degree atmosphere/land version of the CCSM, Clim. Dynam., 34, 6, 819-833, doi:10.1007/s00382-009-0614-8, 2010.

Gromov, S., Jöckel, P., Sander, R., \& Brenninkmeijer, C. A. M.: A kinetic chemistry tagging technique and its application to modelling the stable isotopic composition of atmospheric trace gases, Geoscientific Model Development, 3, 337-364, doi: 10.5194/gmd-3-337-2010, URL (2010)

Hairer, E. and Wanner, G.: Solving Ordinary Differential Equations II. Stiff and DifferentialAlgebraic Problems, Springer-Verlag, Berlin, 1991. 
Henze, D.K., Hakami, A., and Seinfeld, J.H.: Development of the adjoint of GEOS-Chem, Atmos. Chem. Phys., 7, 2413-2433, 2007.

Jöckel, P., Tost, H., Pozzer, A., Brühl, C., Buchholz, J., Ganzeveld, L., Hoor, P., Kerkweg, A., Lawrence, M. G., Sander, R., Steil, B., Stiller, G., Tanarhte, M., Taraborrelli, D., van Aardenne, J., \& Lelieveld, J.: The atmospheric chemistry general circulation model ECHAM5/MESSy1: consistent simulation of ozone from the surface to the mesosphere, Atmos. Chem. Phys., 6, 5067-5104, doi: 10.5194/acp-6-5067-2006, 2006.

Keene, W. C., Long, M. S., Pszenny, A. A. P., Sander, R., Maben, J. R., Wall, A. J., O'Halloran, T. L., Kerkweg, A., Fischer, E. V., and Schrems, O.: Latitudinal variation in the multiphase chemical processing of inorganic halogens and related species over the eastern North and South Atlantic Oceans, Atmos. Chem. Phys., 9, 7361-7385, doi:10.5194/acp-9-7361-2009, 2009.

Kerkweg, A., Sander, R., Tost, H., Jöckel, P., and Lelieveld, J.: Technical note: Simulation of detailed aerosol chemistry on the global scale using mecca-aero, Atmos. Chem. Phys., 7, 2973-2985, 2007.

Kerkweg, A., Jöckel, P., Pozzer, A., Tost, H., Sander, R., Schulz, M., Stier, P., Vignati, E., Wilson, J., \& Lelieveld, J.: Consistent simulation of bromine chemistry from the marine boundary layer to the stratosphere Part 1: Model description, sea salt aerosols and $\mathrm{pH}$, Atmospheric Chemistry and Physics, 8, 5899-5917, doi: 10.5194/acp-8-5899-2008, 2008a.

Kerkweg, A., Jöckel, P., Warwick, N., Gebhardt, S., Brenninkmeijer, C. A. M., and Lelieveld, J.: Consistent simulation of bromine chemistry from the marine boundary layer to the stratosphere Part 2: Bromocarbons, Atmospheric Chemistry and Physics, 8, 5919-5939, doi: 10.5194/acp-8-5919-2008b.Kirner, O., Ruhnke, R., Buchholz-Dietsch, J., Jöckel, P., Brühl, C., and Steil, B.: Simulation of polar stratospheric clouds in the chemistry-climate-model EMAC via the submodel PSC, Geoscientific Model Development, 4, 169-182, doi: 10.5194/gmd-4-169-2011, URL, 2011.

Landgraf, J. and Crutzen, P. J.: An Efficient Method for online calculations of Photolysis and Heating Rates, J. Atmos. Sci., 55, 863-878, 1998.

Lin, S.-J., and Rood, R. B.: Multidimensional flux form semi-Lagrangian transport schemes, Mon. Wea. Rev., 124, 2046-2070, 1996. 
Liu, X., Easter, R. C., Ghan, S. J., Zaveri, R., Rasch, P., Shi, X., Lamarque, J.-F., Gettelman, A., Morrison, H., Vitt, F., Conley, A., Park, S., Neale, R., Hannay, C., Ekman, A. M. L., Hess, P., Mahowald, N., Collins, W., Iacono, M. J., Bretherton, C. S., Flanner, M. G., and Mitchell, D.: Toward a minimal representation of aerosol direct and indirect effects: model description and evaluation, Geosci. Model Dev., 5, 709-739, doi:10.5194/gmd-5-709-2012, 2011.

Mirin A., Worley, P. H.: Improving the performance scalability of the community atmosphere model, International Journal of High Performance Computing Applications 26, 17-30, doi:10.1177/1094342011412630, 2011.

Sander R., and Baumgaertner, A., Gromov, S., Harder, H., Jöckel, P., Kerkweg, A., Kubistin, D., Regelin, E., Riede, H., Sandu, A., Taraborrelli, D., Tost, H. and Xie, Z.-Q.: The atmospheric chemistry box model CAABA/MECCA-3.0, Geosci. Model Dev. 4, 373-380, 2011 http://www.geosci-model-dev.net/4/373

Sander, R., Kerkweg, A., Jöckel, P., and Lelieveld, J.:, Technical Note: The new comprehensive atmospheric chemistry module MECCA, Atmos. Chem. Phys., 5, 445-450, 2005.

Sander, R., Crutzen, P.J.: Model study indicating halogen activation and ozone destruction in polluted air masses transported to the sea, J. Geophys. Res., 101, 9121-9138, 1996.

Sandu A., and Sander, R.: Technical note: Simulating chemical systems in Fortran90 and Matlab with the Kinetic PreProcessor KPP-2.1, Atmos. Chem. Phys., 6, 187-195, 2006, http://www.atmos-chem-phys.net/6/187.

Sandu, A., Verwer, J.G., Blom, J.G., Spee, E.J., Carmichael, G.R., Potra, F.A.: Benchmarking stiff ode solvers for atmospheric chemistry problems II: Rosenbrock solvers. Atmos. Env., 31, 3459-3472, doi:10.1016/S1352- 2310(97)83212-8, 1997.

Schwartz, S. E.: Mass-transport considerations pertinent to aqueous phase reactions of gases in liquid-water clouds, in Chemistry of Multiphase Atmospheric Systems, NATO ASI Series, Vol. G6, edited by W. Jaeschke, pp. 415-471, Springer Verlag, Berlin, 1986.

Strahan, S. E., Douglass, A. R., Stolarski, R. S., Akiyoshi, H., Bekki, S., Braesicke, P., Butchart, N., Chipperfield, M. P., Cugnet, D., Dhomse, S., Frith, S. M., Gettelman, A., Hardiman, S. C., Kinnison, D. E., Lamarque, J.-F., Mancini, E., Marchand, M., Michou, M., Morgenstern, O., Nakamura, T., Olivié, D., Pawson, S., Pitari, G., Plummer, D. A., Pyle, J. A., Scinocca, J. F., Shepherd, T. G., Shibata, K., Smale, D., Teyssèdre, H., Tian, W., \& 
446 Yamashita, Y.: Using transport diagnostics to understand chemistry climate model ozone 447 simulations, J. Geophys. Res., 116, D17302, doi: 10.1029/2010JD015360, 2011.

448 Verwer, J.G., Spee, E.J., Blom, J.G., Hundsdorfer, W.: A Second-Order Rosenbrock Method 449 Applied to Photochemical Dispersion Problems. SIAM J. Sci. Comp., 20:1456-1480, 450 doi:10.1137/S1064827597326651, 1999.

451 von Kuhlmann, R., Lawrence, M. G., Crutzen, P., and Rasch, P.: A model for studies of 452 tropospheric ozone and nonmethane hydrocarbons: Model description and ozone results, J. 453 Geophys. Res., 108, 4294, doi:10.1029/2002JD002893, 2003. 
Figure 1. Schematic showing the order of relevant chemistry, dynamics and physics routines (light gray boxes) over a single model

455 time iteration $(\Delta t)$ relative to the MECCA (white horizontal bar) and the modal-CAM (gray dark-gray horizontal bar) tracer arrays.

456 Boxes indicating model operations are oriented vertically across the tracer array bars to indicate whether they interact with one or both tracer arrays. Step indices correspond to those described in the text (see Section 4).

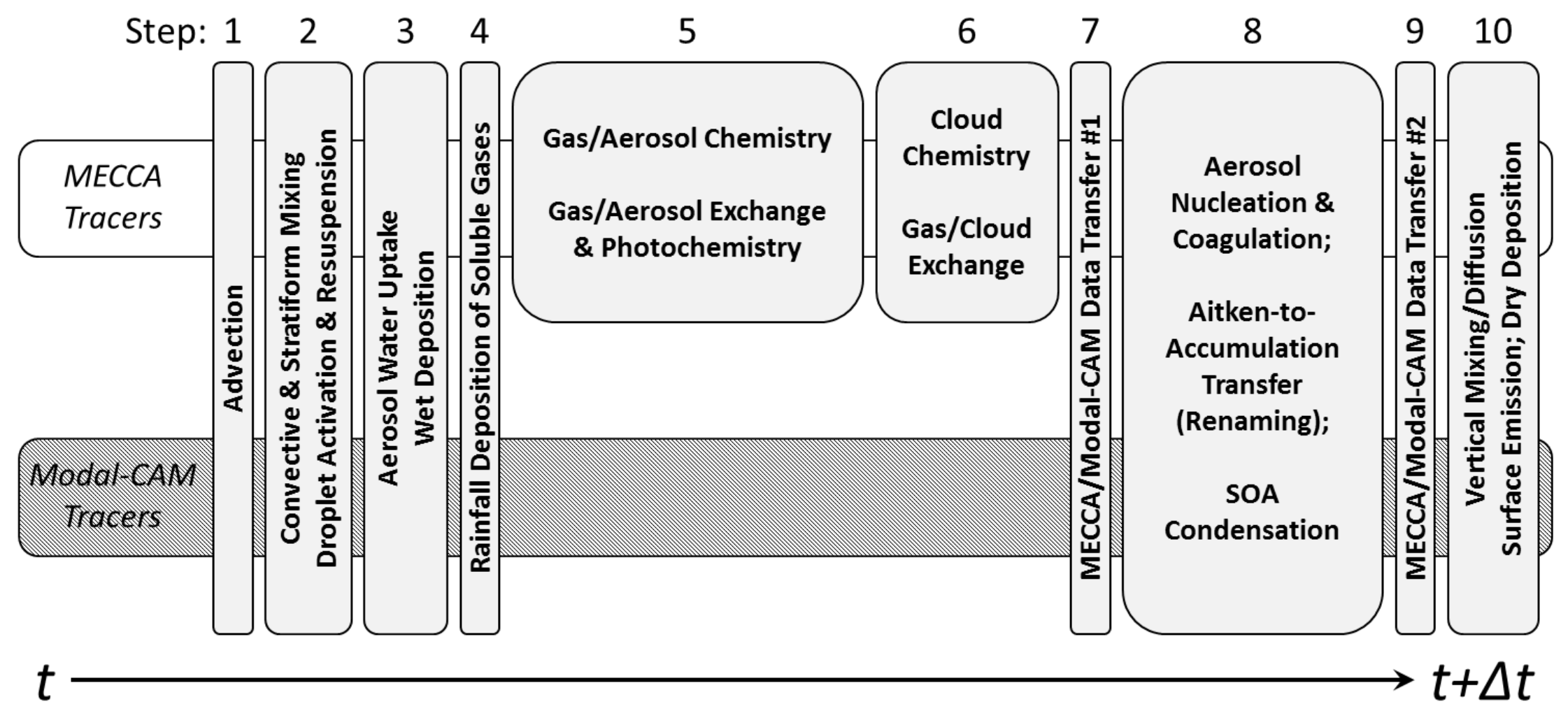


459 Figure 2. Comparison of $\mathrm{O}_{3}$ ( $\mathrm{a}$ and b), $\mathrm{OH}(\mathrm{c}$ and $\mathrm{d}), \mathrm{Br}_{2}$ (e and f), and coarse mode $\mathrm{H}^{+}$( $\mathrm{g}$ and $\mathrm{h}$ )

460 at grid boxes between the surface and $900 \mathrm{mb}$ from one-month benchmark simulations using

461 RODAS-3 (left column X axis) and Ros-2 (right column X axis) solvers versus Ros-3 (Y axis)

462 over the same time period. Black lines depict least-squares standard linear regressions (see Table $4631)$.

464
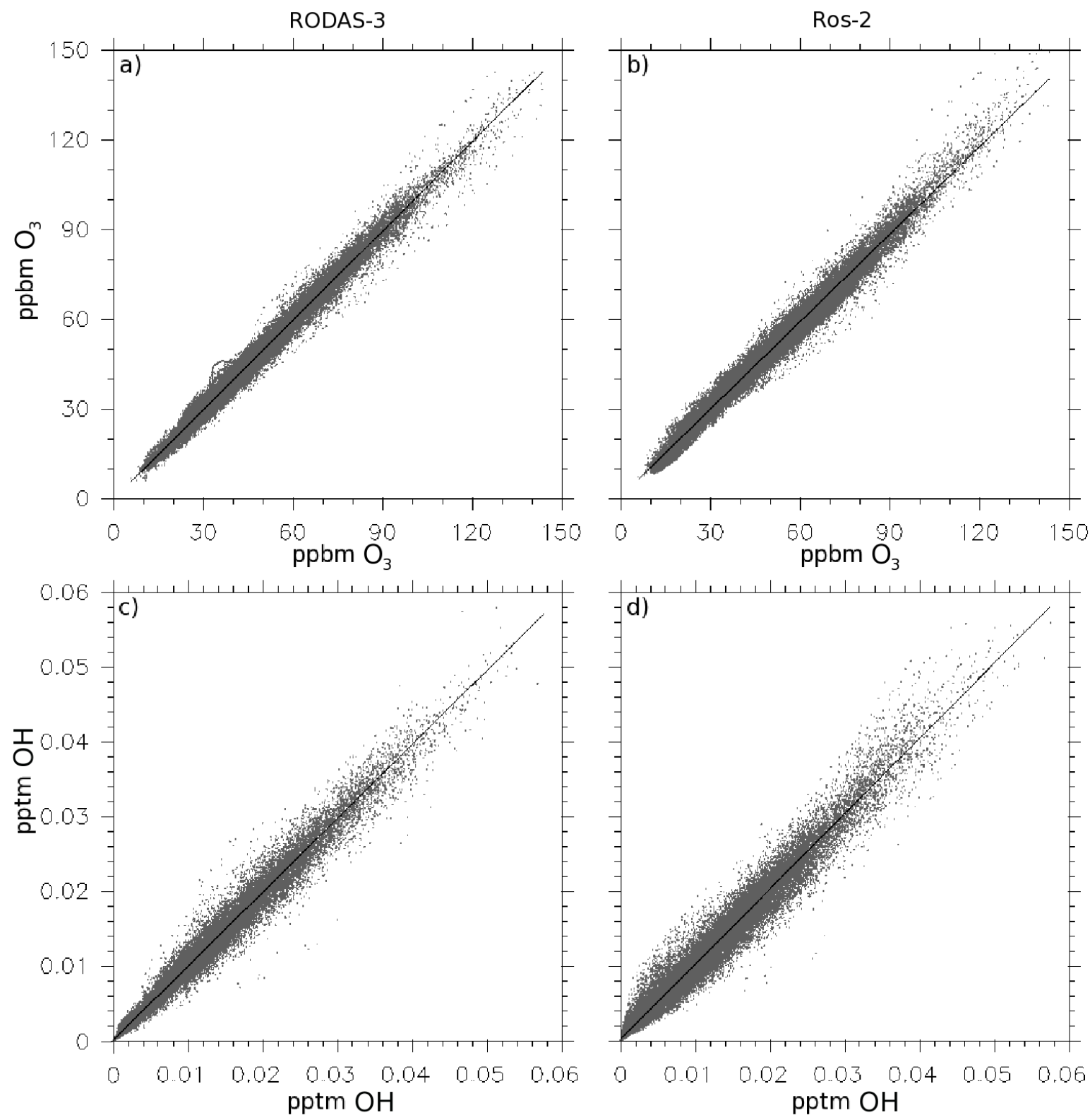

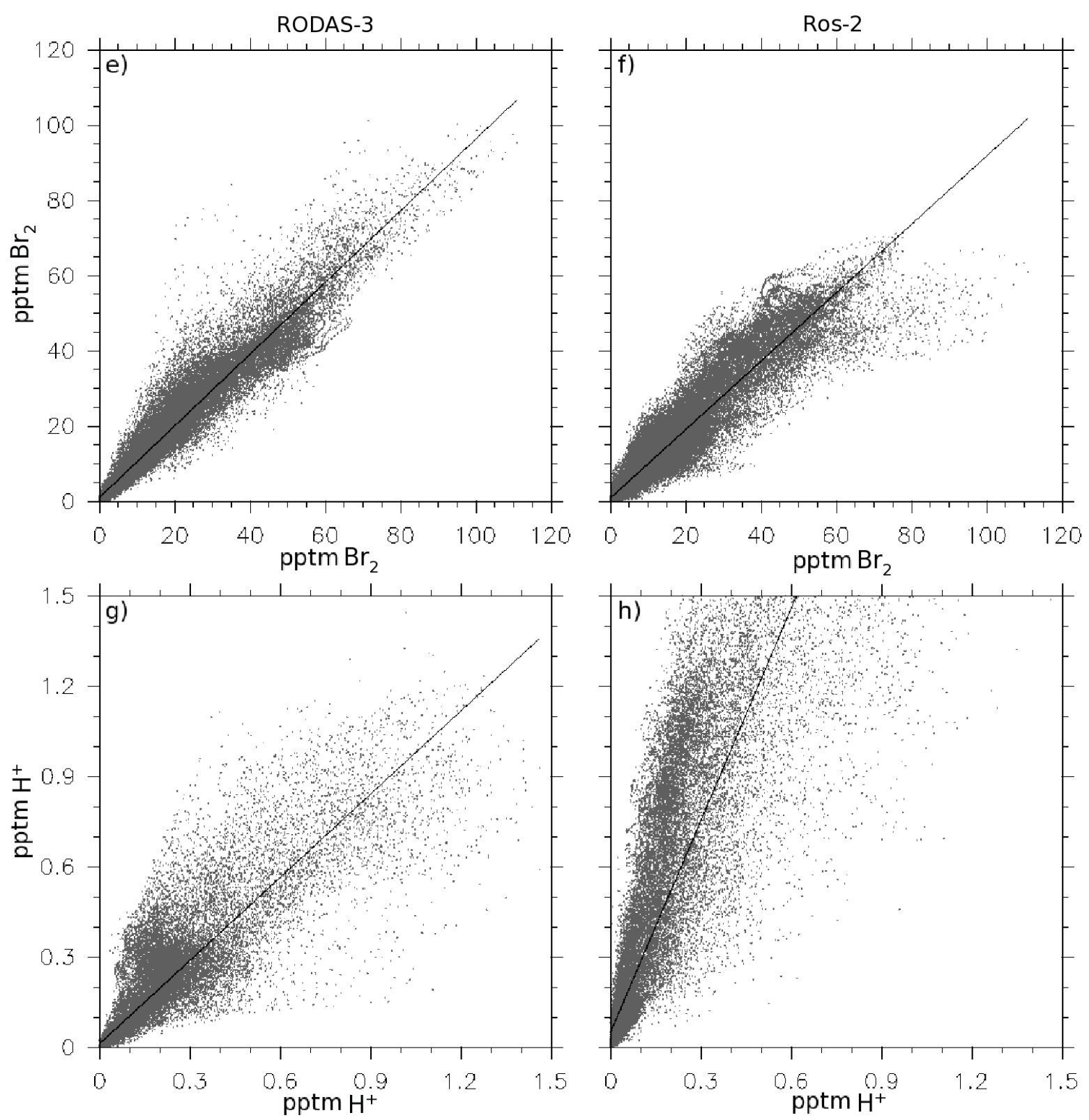

466 
467 Figure 3. Histogram of the percent frequency distribution of per grid-box chemistry integration 468 times (in milliseconds) using MECCA in the modal-CAM global atmosphere for the one-month 469 benchmarks using three different Rosenbrock solvers.

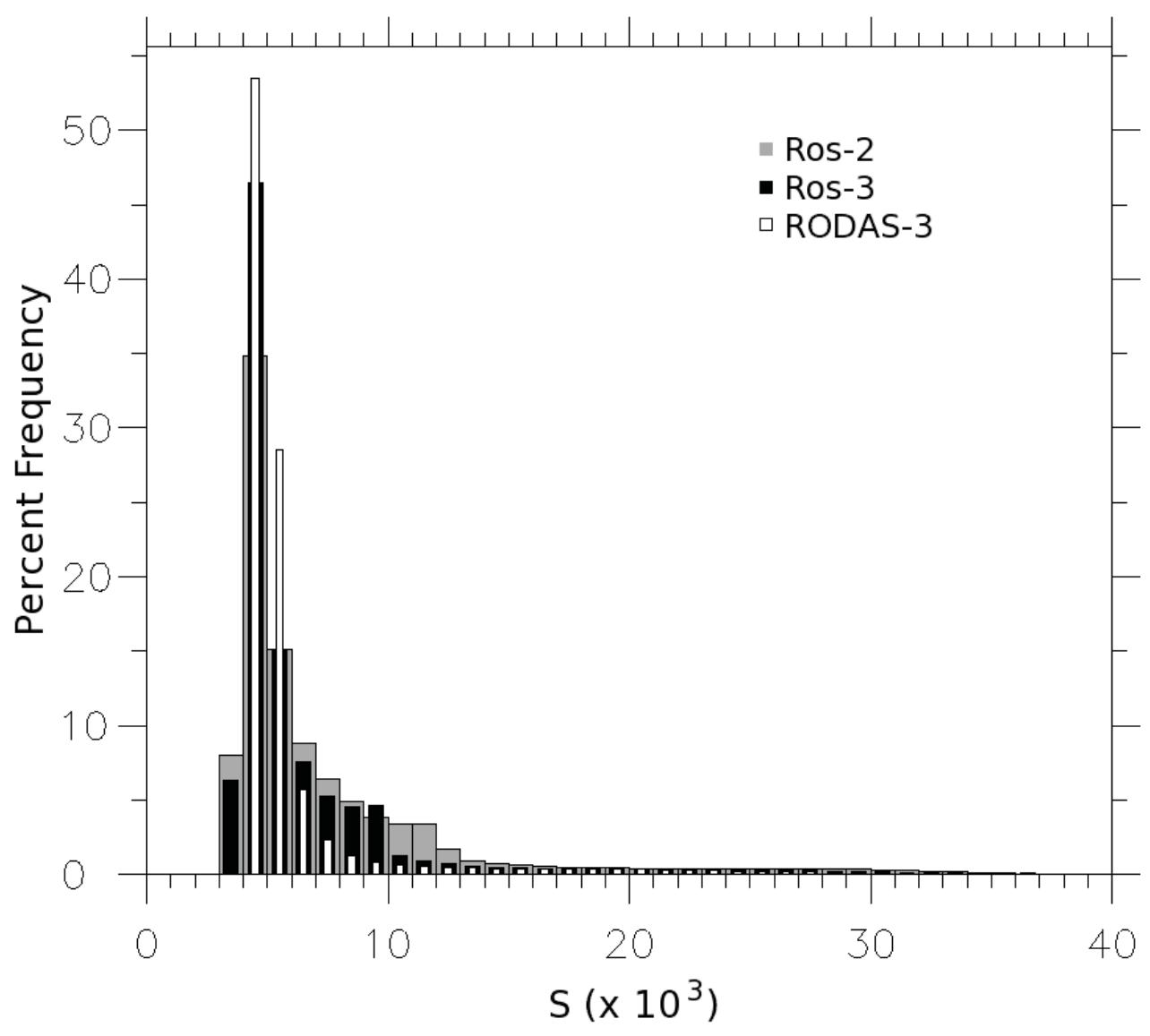


471 Table 1. Comparison of one-month benchmark simulations of the coupled modal-CAM/MECCA

472 system for Ros-2 and RODAS-3 solvers versus Ros-3.

\begin{tabular}{ccccc} 
& Species & Regression Line & $\mathrm{R}^{2}$ & RMSE (\%) \\
\hline Ros-2 & $\mathrm{O}_{3}$ & $0.98 \mathrm{x}+0.56$ & 0.99 & $6.5 \%$ \\
& $\mathrm{OH}$ & $1.0 \mathrm{x}+1.5 \times 10^{-4}$ & 0.98 & $17 \%$ \\
& $\mathrm{Br}_{2}$ & $0.91 \mathrm{x}+0.87$ & 0.94 & $42 \%$ \\
& $\mathrm{H}^{+}(\mathrm{Coarse}$ & $2.35 \mathrm{x}+0.048$ & 0.93 & $410 \%$ \\
$\mathrm{Mode})$ & $0.98 \mathrm{x}-0.36$ & 0.99 & $5.1 \%$ \\
\hline RODAS- & $\mathrm{O}_{3}$ & $0.99+7.3 \times 10^{-5}$ & 0.99 & $11 \%$ \\
& $\mathrm{OH}$ & $0.95 \mathrm{x}+0.98$ & 0.97 & $29 \%$ \\
& $\mathrm{Br}_{2}$ & $0.92+0.011$ & 0.97 & $120 \%$ \\
& $\mathrm{H}^{+}(\mathrm{Coarse}$ & & \\
\hline
\end{tabular}

473 
474 Part II: Sensitivity of tropospheric chemical composition to halogen-radical chemistry using a

475 fully coupled GCM/size-resolved multiphase chemical system I: Halogen distributions,

476 aerosol composition, and sensitivity of climate-relevant gases.

477

478 M.S. Long (mlong@ seas.harvard.edu)

479 School of Engineering and Applied Sciences, Harvard University, Cambridge, MA, $480 \quad$ USA

481 W.C. Keene (wck@ virginia.edu)

482 Department of Environmental Sciences, University of Virginia, Charlottesville, VA 483 22904, USA

484 R. C. Easter (Richard.Easter@pnnl.gov)

485 Atmospheric Sciences and Global Change Division, Pacific Northwest National

$486 \quad$ Laboratory

487 R. Sander (rolf.sander@mpic.de)

488 Air Chemistry Department, Max-Planck Institute of Chemistry, 55020 Mainz,

489 Germany

490 X. Liu (xiaohong.liu@pnnl.gov)

$491 \quad$ Atmospheric Science and Global Change Division, Pacific Northwest National

492 Laboratory, Richland, Washington, USA

493 A. Kerkweg (kerkweg@uni-mainz.de)

494 Institute for Atmospheric Physics, University of Mainz, 55099 Mainz, Germany

495 D. Erickson (ericksondj@ornl.gov)

496 Computer Science and Mathematics Division, Oak Ridge National Laboratory,

497 Oak Ridge, TN USA 
Observations and model studies suggest a significant but highly non-linear role for

500 halogens, primarily $\mathrm{Cl}$ and $\mathrm{Br}$, in multiphase atmospheric processes relevant to tropospheric

501 chemistry and composition, aerosol evolution, radiative transfer, weather, and climate. The

502 sensitivity of global atmospheric chemistry to the production of marine aerosol and the

503 associated activation and cycling of inorganic $\mathrm{Cl}$ and $\mathrm{Br}$ was tested using a size-resolved

504 multiphase coupled chemistry/Global Climate model (National Center for Atmospheric

505 Research's Community Atmosphere Model (CAM); v3.6.33). Simulation results showed

506 strong meridional and vertical gradients in $\mathrm{Cl}$ and $\mathrm{Br}$ species. The simulation reproduced

507 most available observations with reasonable confidence permitting the formulation of

508 potential mechanisms for several previously unexplained halogen phenomena including the

509 enrichment of $\mathrm{Br}^{-}$in submicron aerosol, and the presence of a $\mathrm{BrO}$ maximum in the polar free

510 troposphere. However, simulated total volatile $\mathrm{Br}$ mixing ratios were generally high in the

511 troposphere. $\mathrm{Br}$ in the stratosphere was lower than observed due to the lack of long-lived

512 organobromine species in the simulation. Comparing simulations using chemical mechanisms

513 with and without reactive $\mathrm{Cl}$ and $\mathrm{Br}$ species demonstrated a significant temporal and spatial

514 sensitivity of primary atmospheric oxidants $\left(\mathrm{O}_{3}, \mathrm{HO}_{\mathrm{x}}, \mathrm{NO}_{\mathrm{x}}\right), \mathrm{CH}_{4}$, and non-methane

515 hydrocarbons (NMHC's) to halogen cycling. Simulated $\mathrm{O}_{3}$ and $\mathrm{NO}_{\mathrm{x}}$ were globally lower

516 (65\% and 35\%, respectively, less in the planetary boundary layer based on median values) in

517 simulations that included halogens. Globally, little impact was seen in $\mathrm{SO}_{2}$ and non-sea-salt

$518 \mathrm{SO}_{4}{ }^{2-}$ processing due to halogens. Significant regional differences were evident: The lifetime

519 of nss- $\mathrm{SO}_{4}{ }^{2-}$ was extended downwind of large sources of $\mathrm{SO}_{2}$. The burden and lifetime of

520 DMS (and its oxidation products) were lower by a factor of 5 in simulations that included

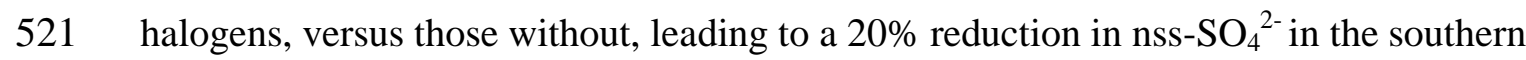

522 hemisphere planetary boundary layer based on median values. 


\section{Introduction}

526 The development of comprehensive global Earth system models that are able to accurately

527 simulate the climate system requires detailed understanding and treatment of multiphase

528 atmospheric processes relevant to aerosol evolution and radiative transfer. However, due in

529 part to limitations in computational power relative to numerical needs, most current Earth

530 system models treat the physicochemical processing of size-resolved aerosols using

531 parameterizations that are computationally conservative but, in many respects, inadequate to

532 reliably characterize aerosol-climate interactions. These limitations contribute to the large

533 uncertainties in the radiative effects of atmospheric aerosols, which are among the major

534 factors that constrain our current understanding of and ability to predict global climate

535 change.

536 Reliable simulation of the physical and chemical evolution of aerosols in the Community

537 Climate System Model (CCSM) and other Earth systems models requires explicit evaluation

538 of processes as a function of size. Because of direct physical feedbacks, representative

539 simulation of climatic influences also requires an interactive online scheme for aerosol

540 microphysics and multiphase chemistry. A number of major issues must be considered to

541 implement such a scheme. Direct interactions between relatively long-lived and fast-reacting

542 species coupled with large concentration and size gradients of both aerosols and important

543 related atmospheric constituents such as water vapor (e.g., Kerkweg et al., 2007), introduces

544 a high degree of numerical stiffness that is unevenly distributed across the gridded model

545 domain.

546 The size- and composition-dependent properties of aerosols significantly influence

547 radiative fluxes through the atmosphere via two sets of interrelated processes. First, aerosols

548 scatter and absorb incident and outgoing radiation and thereby directly influence net radiative

549 transfer through the atmosphere and the associated distribution and partitioning of heat (and

550 related kinetic and thermodynamic properties). Second, aerosols act as cloud condensation

551 nuclei $(\mathrm{CCN})$ and thereby influence the microphysical properties of clouds including droplet

552 number, size distribution, and lifetime. Through this latter set of processes, aerosols

553 indirectly regulate radiative transfer via the associated modulation of physicochemical 
554 evolution and albedo of clouds. These processes also influence precipitation fields and, thus,

555 the hydrologic cycle and related climatic feedbacks.

556 Aerosols also interact directly in the cycling and associated climatic effects of important 557 tropospheric gases, particularly over the ocean. The production from marine-derived

558 precursors and multiphase cycling of halogen radicals represents a significant net sink for 559 ozone in the remote marine boundary layer (MBL) (Dickerson et al., 1999; Galbally et al., 560 2000; Nagao et al., 2000; Sander et al., 2003; Pszenny et al., 2004; Keene et al., 2009) and a 561 potentially important net source in polluted coastal (Tanaka et al., 2003; Osthoff et al., 2008) 562 and continental air (Thornton et al., 2010). The associated formation and scavenging of 563 halogen nitrates accelerates the conversion of $\mathrm{NO}_{x}$ to $\mathrm{HNO}_{3}$ and particulate $\mathrm{NO}_{3}{ }^{-}$thereby 564 contributing to net $\mathrm{O}_{3}$ destruction (Sander et al., 1999; Pszenny et al. 2003; Keene et al., 565 2009). Marine-derived halogen radicals ( $\mathrm{BrO}$ and atomic $\mathrm{Cl}$ ) oxidize $(\mathrm{CH} 3)_{2} \mathrm{~S}$ (dimethyl 566 sulfide, DMS) in the gas phase (Toumi, 1994; Keene et al., 1996; Saiz-Lopez et al., 2004) 567 and hypohalous acids oxidize S(IV) in aerosol solutions (Vogt et al., 1996; Keene et al., 568 1998; von Glasow et al., 2002; von Glasow and Crutzen, 2004). The large surface area of 569 primary marine aerosols also competes efficiently with nuclear clusters (from gas-to-particle 570 reactions) for condensable reaction products from the oxidation of gaseous precursors

571 (including $\mathrm{H}_{2} \mathrm{SO}_{4}$ from $\mathrm{SO}_{2}$ oxidation) thereby diminishing the potential for clusters to grow 572 to sustainable size. Consequently, the climatic influences of sulfur cycling may be 573 substantially less than predicted based on models that do not explicitly evaluate interactions 574 involving primary marine aerosols. Chlorine radicals also oxidize methane (an important 575 greenhouse gas) (Platt et al., 2004; Lawler et al., 2009) and non-methane hydrocarbons 576 (Keene et al., 2007; Pszenny et al., 2007), which leads to the production of condensable 577 organic compounds that contribute to aerosol growth and, in the presence of sufficient $\mathrm{NO}_{\mathrm{x}}$, 578 peroxy radicals that enhance oxidation potential. The photochemical processing of marine579 derived organic compounds is an important source of $\mathrm{OH}$ and other radicals that enhance 580 oxidation potential within aerosol solutions (McDow et al., 1996; Zhou et al., 2006;

581 Anastasio et al., 2007).

582 In terms of mass flux, bursting bubbles produced by breaking waves at the ocean surface 583 are the largest source of aerosols in Earth's atmosphere (Andreae and Rosenfeld, 2008). The 584 nascent droplets dehydrate into equilibrium with ambient water vapor and undergo other 585 rapid (seconds) multiphase transformations involving the scavenging of gases, aqueous and 586 surface reactions, and volatilization of products. (e.g., Chameides and Stelson, 1992; 
Erickson et al., 1999; Sander et al., 2003). The sub- $\mu \mathrm{m}$ fractions dominate number concentrations and associated direct and indirect influences on radiative transfer and climate (e.g., O'Dowd et al., 1997).

In this paper, the sensitivity of global atmospheric chemistry to the production of marine aerosol and the associated activation and cycling of inorganic $\mathrm{Cl}$ and $\mathrm{Br}$ was tested using a 3mode size-resolving aerosol module (Modal Aerosol Module) version of the threedimensional (3-D) National Center for Atmospheric Research's Community Atmosphere Model (CAM version 3.6.33; Gent et al., 2009; Liu et al., 2012; hereafter referred to as modal-CAM) coupled to the multiphase chemical module MECCA (Module Efficiently Calculating the Chemistry of the Atmosphere; Sander et al., 2005). The companion paper by

597 Long et al. (2012) describes the coupled modeling system in detail. A follow-up manuscript 598 will evaluate the sensitivity of climate to halogen cycling and the implications of multiphase processes for aerosol populations and cloud microphysical properties.

2. Model Description

Atmospheric processes were simulated in 3-D using modal-CAM at $1.9^{\circ} \times 2.5^{\circ}$ lat-long resolution with 26 vertical levels (Gent et al., 2009). Modal-CAM is a FORTRAN90 compliant general circulation system built upon an extensive set of high-performance computational routines to preserve scalability and performance of the model across changes in resolution and model physics.

The dynamical core (approximation of the equations of motion on a discrete, spherical grid) is based on a flux-form semi-Lagrangian method better suited for tracer transport. This approach permits grid-wide stability of the chemistry solution, in contrast to discrete methods that introduce large dispersion and diffusion errors in their approximation of the equations of motion which propagate into and destabilize the chemistry solver.

618 to be in the form of $\mathrm{NH}_{4} \mathrm{HSO}_{4}$. OM and $\mathrm{BC}$ are treated only in the accumulation mode. SOA

619 is only in the Aitken and accumulation modes, and mineral dust is only in the accumulation 
and coarse modes. Aerosol number and aerosol water are also calculated for each mode. Aerosol mass and number associated with stratiform cloud droplets are treated explicitly.

Size-resolved emissions of particle number, inorganic sea-salt, and OM mass from the surface ocean were calculated in CAM as functions of wind speed and surface ocean chl $a$ based on Long et al. (2011). Modeled size bins were centered on 0.039, 0.076, 0.15, 0.52, $2.4,4.9,15.1$ and $30-\mu \mathrm{m}$ diameters at $98 \%$ relative humidity (i.e., $\mathrm{RH}$ within the laminar sublayer immediately above the air-sea interface) across bin widths $\left(\mathrm{d} D_{p}\right)$ of $0.03,0.05,0.1,0.2$, $1.0,3.0,10.0$ and $20.0 \mu \mathrm{m}$, respectively. Following dehydration to equilibrium water contents at an average $\mathrm{RH}$ of $80 \%$ in the mixed layer above the laminar sub-layer, compositions were summed over the three aerosol size modes considered by CAM. Since the 3 -mode version of CAM considers OM mass only in the accumulation mode, the OM mass was summed over all particle sizes below 1.0- $\mu \mathrm{m}$ diameter at $80 \% \mathrm{RH}$, and emitted directly into the accumulation mode (mode-1).

\subsection{Prescribed Conditions and Initializations}

$\mathrm{CH}_{4}, \mathrm{~N}_{2} \mathrm{O}$, and $\mathrm{CO}_{2}$ mixing ratios were fixed at $1.77,0.32$, and 378 ppmv, respectively. $\mathrm{O}_{3}$ was calculated online. Direct surface emissions of DMS, $\mathrm{SO}_{2}$, secondary organic aerosol precursor gases, subgrid-scale $\mathrm{NH}_{4} \mathrm{HSO}_{4}$ (mode- 1 and mode-2), $\mathrm{NH}_{3}$, and $\mathrm{NO}_{\mathrm{x}}$ were based on Dentener et al. (2006). Surface emissions of $\mathrm{CO}, \mathrm{CH}_{3} \mathrm{OH}, \mathrm{C}_{2} \mathrm{H}_{4}, \mathrm{C}_{3} \mathrm{H}_{6}, \mathrm{C}_{3} \mathrm{H}_{8}$, and isoprene were based on the Precursors of Ozone and their Effects in the Troposphere (POET) database for 2000 (Granier et al., 2005).

644 burden of running the MECCA mechanism, and to reduce model spin-up time, the sea-

645 surface temperature was based on offline data for the 2000 calendar year, and was cycled 646 annually. The sea-ice interface used version 4 of the Community Sea Ice Model (CSIM4;

647 Briegleb et al., 2002). The land interface used version 2 of the Community Land Model 648 (CLM2; Dickenson et al., 2006). Fields of chl $a$ concentrations (in units of $\mathrm{mg} \mathrm{m}^{-3}$ ) in surface 649 seawater were set equal to monthly averages derived from SeaWIFS imagery $\left(1^{\circ} \times 1^{\circ}\right.$, 650 Gregg, 2008) for the period September 1997 through December 2002, as in Long et al. 651 (2012). The aerosol modes were initialized at zero number with sizes centered log-normally 652 on $0.026,0.11$, and $2.0 \mu \mathrm{m}$ geometric mean dry diameters for the Aitken, accumulation, and 
653 coarse modes, respectively. The corresponding ranges for the log-normal centroids were

6540.0087 to $0.052,0.053$ to 0.44 , and 1.0 to $4.0 \mu \mathrm{m}$ dry diameter respectively.

2.4 Global Simulations and Reporting Conventions

657 Results for the coupled MECCA scheme, for which chemical reactions involving halogens 658 were calculated explicitly (denoted $\mathrm{Hal}$ ), were compared with corresponding runs for which

659 halogen chemistry was turned off (denoted $\mathrm{NoHal}$ ). Differences in results were interpreted to 660 evaluate the role of halogens in the physicochemical evolution of the atmosphere.

661 Unless otherwise stated, the following conventions are used. Values are based on grid-box 662 area-weighted spatial fields for the simulated period from January, 12005 - December, 31

663 2014. Notation is specified for atmospheric region and time period over which statistics were 664 calculated. Ten-year area-weighted statistics are referred to as ANN for annual, DJF for 665 December/January/February, MAM for March/April/May, and JJA for June/July/August.

666 Spatial statistics for specific atmospheric regions were compiled over the northern and 667 southern hemispheres, ( $\mathrm{NH}$ and $\mathrm{SH}$, respectively), the entire planetary boundary layer (PBL), 668 the continental-only boundary layer (CBL), marine-only boundary layer (MBL), and the 669 entire free troposphere (FT). Model layers corresponding to these regions are defined below. 670 Analyses based on specific model layers (e.g. the surface layer) are specified as such. Results 671 for a given atmospheric region are based on median and range of 10-year mean climatology 672 for that region and time period (as defined above). For example, the annual $\mathrm{O}_{3}$ mixing ratio 673 for the planetary boundary layer (ANN-PBL) would be reported as the median and range 674 across the PBL of the 10-year climatological mean.

675 Temporal-only statistics for a given grid box are reported as mean \pm standard deviation.

676 The $\mathrm{O}_{3}$ mixing ratio corresponding to a long-term measurement site would be reported only 677 as a 10-year climatological mean and standard deviation. When necessary to facilitate direct 678 comparison with observations or results from other published simulations, simulated results 679 are reported using the same convention as the reported values.

680 For all discussions here, the tropopause was defined as the minimum pressure level in the 681 model (maximum altitude) above which the temperature lapse rate was positive between 682 levels (70.06 mb or $\sim 18 \mathrm{~km}$ ), which is consistent with the World Meteorological 683 Organization's tropopause definition. In CAM, the boundary layer is not well resolved, and 684 was therefore defined as the lowest four levels (highest pressure) of the model atmosphere 685 (below $867 \mathrm{mb}$ ). The free troposphere was defined as the region between the top of the 
boundary layer and the tropopause. For comparisons with measurements at surface sites for

687 which altitudes are known, simulated results were interpolated vertically to the corresponding

688 measurement altitudes. Otherwise, the results from the likely nearest model pressure level

689 were used. Unless otherwise noted, comparisons between results for $\mathrm{Hal}$ relative to $\mathrm{NoHal}$

690 simulations are presented as percent deviation defined as (using $\mathrm{O}_{3}$ as an example),

$$
\% \operatorname{Deviation}\left(\mathrm{O}_{3}\right)=\frac{\left[\mathrm{O}_{3}\right]_{\mathrm{Hal}}-\left[\mathrm{O}_{3}\right]_{\mathrm{NoHal}}}{\left[\mathrm{O}_{3}\right]_{\mathrm{NoHal}}} \times 100
$$

3. Results

\subsection{Marine Aerosol Population Characteristics}

694 Mean aerosol composition and mixing ratios of gases simulated for each atmospheric region are compiled in supplemental material (Tables S1 and S2). Globally averaged annual marine aerosol production flux, burden, dry and wet deposition for both the Hal and NoHal (not shown, since these marine aerosol statistics were virtually identical for the simulated time period) simulations fell within the range of published estimates (Table 1). The total $\mathrm{Na}^{+}$ mass flux was $25 \%$ less than that reported by Long et al. (2011), which resulted in part from differences in model physics between the different CAM versions used in the two studies (3.5.07 for Long et al., 2011 and 3.6.33 here) and the number of aerosol size bins considered ( 8 for Long et al., 2011 and 3 here). The corresponding spatial range in mean $\mathrm{Na}^{+}$lifetimes against deposition was also within that reported by Pierce and Adams (2006) of 0.46 to 2.72

704 days. Mean dry deposition fluxes are towards the lower end of published estimates whereas 705 wet fluxes fall near the mid-range of published estimates. Available evidence indicates that

706 cloud and precipitation processes are represented reasonably well within CAM3 (e.g. Boville 707 et al., 2006), which implies that simulated deposition fluxes are also reasonable.

\subsection{Model Sensitivity to Inorganic Halogen Cycling}

710 For the simulations reported herein, dehalogenation of marine aerosol is the only primary 711 source for volatile inorganic $\mathrm{Br}$ and $\mathrm{Cl}$ species. Because emissions of halocarbons from

712 marine biogenic sources, biomass- and fossil-fuel combustions, industrial sources, and

713 terrestrial ecosystems, are not considered, the total global emissions of halogens correspond 714 to lower limits. In addition, as discussed in detail by Keene et al. (2009), available evidence 715 suggests that the MECCA scheme as currently configured overestimates rates of Br cycling

716 to some extent and consequently, simulated rates of $\mathrm{Br}$ activation and associated impacts are 
717 considered upper limits. In the following text and tables, $\mathrm{Br}_{\mathrm{t}}$ is defined as the sum of all

718 volatile inorganic $\mathrm{Br}$ species and $\mathrm{Cl}^{*}$ is defined as all inorganic $\mathrm{Cl}$ gases other than $\mathrm{HCl}$,

719 which includes $\mathrm{HOCl}, 2 \times \mathrm{Cl}_{2}, \mathrm{ClNO}_{2}, \mathrm{ClNO}_{3}, \mathrm{OClO}$, and $\mathrm{BrCl}$.

\subsubsection{Br Distributions}

722 Simulated $\mathrm{Br}_{\mathrm{t}}$ averaged over the tropospheric column ranged from 0.038 to $44 \mathrm{pmol} \mathrm{mol}^{-1}$

723 (median 6.1 pmol mol ${ }^{-1}$ ). Median $\mathrm{Br}_{\mathrm{t}}$ for ANN-FT was 2.5 (0.038 to 32) $\mathrm{pmol} \mathrm{mol}^{-1}$. von

724 Glasow et al. (2004) reported $\mathrm{Br}_{\mathrm{t}}$ from 1 to $6 \mathrm{pmol} \mathrm{mol}^{-1}$ for the FT based on simulations that

725 considered $\mathrm{Br}$ sources other than sea-salt aerosol. While these ranges overlap, mixing ratios

726 simulated by von Glasow (2004) are lower limits because the sources do not include marine

727 aerosol production. Simulated zonal median $\mathrm{Br}_{\mathrm{t}}$ reveals little $\mathrm{Br}_{\mathrm{t}}$ in the upper troposphere and

728 stratosphere, which is inconsistent with observation (e.g. Fitzenberger et al., 2000; see

729 Supplemental Figure S1) and model calculations (von Glasow et al., 2004). Most

730 stratospheric $\mathrm{Br}$ is believed to originate from the photolysis of long-lived organic $\mathrm{Br}$ species

731 (e.g. $\mathrm{CH}_{3} \mathrm{Br}$ ) (Montzka et al., 2003), which are not considered in the MECCA chemical

732 mechanism employed for these simulations or the emission fields for Modal-CAM. To

733 achieve observed levels of stratospheric $\mathrm{Br}_{\mathrm{t}}$ with the computational resources available for

734 this analysis would have required offline $\mathrm{Br}$ sources. The radiative transfer scheme used to

735 calculate photochemical rates was tuned to reproduce stratospheric $\mathrm{O}_{3}$ climatological means.

736 Consequently, the impact of the upper-atmosphere $\mathrm{Br}$ on tropospheric photochemistry is

737 believed to be negligible.

738 Global median vertical profiles and speciation of $\mathrm{Br}_{\mathrm{t}}$ for ANN and JJA (Fig. 1) reveal that, 739 between 700 to $800 \mathrm{mb}$ pressure level ( 2 to $3 \mathrm{~km}$ altitude) and the surface, $\mathrm{Br}_{\mathrm{t}}$ is dominated

740 by roughly equal amounts of $\mathrm{Br}_{2}$ and $\mathrm{BrCl}$ on a molecular basis. For DJF, $\mathrm{BrCl}$ was higher

741 than $\mathrm{Br}_{2}$ by a factor of about two. At higher altitudes, $\mathrm{HBr}$ (most of which is produced via the

742 reaction of $\mathrm{Br}+\mathrm{HCHO}$ ) increases to become the dominant gas-phase $\mathrm{Br}$ species. In the lower

743 troposphere, $\mathrm{HBr}$ is efficiently scavenged by liquid aerosol or cloud droplets. In the FT, most

$744 \mathrm{Br}$ is recycled in the gas phase via

$$
\begin{aligned}
& \mathrm{Br}+\mathrm{O}_{3} \rightarrow \mathrm{BrO}+\mathrm{O}_{2} \\
& \mathrm{BrO}+\mathrm{h} v \rightarrow \mathrm{Br}+\mathrm{O}\left({ }_{3} \mathrm{P}\right)
\end{aligned}
$$

with an important secondary pathway (ranging from 5\% to 20\%) through

$$
\begin{aligned}
& \mathrm{BrO}+\mathrm{HO}_{2} \rightarrow \mathrm{HOBr}+\mathrm{O}_{2} \\
& \mathrm{HOBr}+\mathrm{h} v \rightarrow \mathrm{Br}+\mathrm{OH}
\end{aligned}
$$


750 In the $\mathrm{NH}-\mathrm{FT}, \mathrm{BrO}+\mathrm{NO}$ competes with $\mathrm{R} 3$ at approximately equal proportions. In the mid and high latitude $\mathrm{FT}$ of the $\mathrm{NH}$ and $\mathrm{SH}, 7 \%$ to $15 \%$ of $\mathrm{HOBr}$ is converted to $\mathrm{BrCl}$ via the

752 multiphase pathway involving accumulation mode aerosol:

$$
\begin{gathered}
\operatorname{HOBr}(\mathrm{g}) \rightarrow \operatorname{HOBr}(\mathrm{aq}) \\
\mathrm{HOBr}(\mathrm{aq})+\mathrm{Cl}^{-}+\mathrm{H}^{+} \rightarrow \mathrm{BrCl}(\mathrm{aq}) \\
\mathrm{BrCl}(\mathrm{aq}) \rightarrow \mathrm{BrCl}(\mathrm{g})
\end{gathered}
$$

In the MBL, $15 \%$ to $50 \%$ of $\mathrm{HOBr}$ reacts via the above pathway.

Multiphase recycling is not completely inactive in the FT. For example, a persistent but seasonally variable $\mathrm{BrO}$ maximum ranging from 3 to $4 \mathrm{pmol} \mathrm{mol}^{-1}$ was evident in the FT around 500 to $600 \mathrm{mb}$ extending from approximately $60^{\circ} \mathrm{S}$ southward to the pole (Fig. 5a). This was driven by the condensation of $\mathrm{HBr}$ transported from the MBL across a band between $40^{\circ} \mathrm{S}$ to $20^{\circ} \mathrm{S}$ into the FT, southward, leading to the subsequent production (followed by volatilization and photolysis) of $\mathrm{Br}_{2}$ via

$$
\mathrm{HOBr}(\mathrm{aq})+\mathrm{Br}^{-}+\mathrm{H}^{+} \rightarrow \mathrm{Br}_{2}(\mathrm{aq})
$$

Reactions R1 through R4 and R5 through R7 complete the autocatalytic cycle. A recent paper by Roscoe et al. (2012) concluded that a large potential discrepancy between surface and remote-sensing measurements of $\mathrm{BrO}$ in Antarctica was resolved by a high abundance of $\mathrm{BrO}$ in the FT above the surface. . This conclusion is supported by measured vertical profiles of $\mathrm{BrO}$ showing a maximum of nearly $9 \mathrm{pmol} \mathrm{mmol}^{-1}$ at an altitude of $2 \mathrm{~km}$ (approx. 700 to $800 \mathrm{mb}$ ). The general consistency between these observations and our moded results suggests that a significant amount of the $\mathrm{BrO}$ involved in chemistry over the Antarctic ice sheet is seasalt derived. Further, McElroy et al. (1999) saw evidence for a high abundance of BrO in the Arctic FT that the authors were only able to conclude was driven by multiphase chemistry. While we cannot confirm that our results are indeed reflective of the true nature of these observations, they demonstrate a consistent regional-scale performance of our model's halogen cycling mechanism.

Measurements and model calculations indicate that, in the MBL, volatile inorganic $\mathrm{Br}$ typically has a relatively longer atmospheric lifetime against deposition than the parent marine aerosol (e.g., Sander et al., 2003; Keene et al., 2009). In addition, our model calculations indicate that significant amounts of relatively insoluble forms of $\mathrm{Br}_{\mathrm{t}}$ are detrained from the MBL and accumulate in the FT whereas most of the highly soluble parent aerosol is largely confined to the MBL. Br cycling in the FT leads to enrichments in particulate $\mathrm{Br}$ relative to inorganic sea salt (i.e., $\mathrm{EF}(\mathrm{Br})>1$ ) throughout most of the FT (see 
783 Supplement Tables S1 and S2). Two pathways lead to accumulation of Br in aerosols: (1) In

784 the FT, secondary $\mathrm{Br}^{-}$is formed via the oxidation of aqueous $\mathrm{SO}_{2}$ (in the form of $\mathrm{HSO}_{3}{ }^{-}$and

$785 \mathrm{SO}_{3}{ }^{2-}$ ) by $\mathrm{HOBr}$, and (2) the condensation of $\mathrm{HBr}$ onto newly formed and preexisting aerosol.

786 The subsequent entrainment from the FT into the PBL of both Br-enriched aerosols and $\mathrm{HBr}$,

787 most of which subsequently condenses onto existing MBL aerosols, contributes to $\mathrm{Br}^{-}$

788 enrichments in the PBL. The role of this dynamic process is evident in a slight but

789 statistically significant $(\mathrm{p}<0.10)$ negative correlation between $\mathrm{HBr}$ and model vertical

790 velocity (not shown). The incorporation of secondary $\mathrm{Br}^{-}$into fine-mode particles formed via

791 nucleation, and subsequent coagulation into accumulation-mode particles likely affects

$792 \mathrm{EF}(\mathrm{Br})$ across the size distribution, as well. However, since the model does not distinguish

793 between fresh and aged aerosols, the relative contributions of different pathways to simulated

$794 \mathrm{EF}(\mathrm{Br})$ in the PBL cannot be quantified explicitly.

795 Br enrichments in sub- $\mu \mathrm{m}$ fraction aerosol have been observed throughout the MBL (e.g.,

796 Sander et al., 2003) but until now models have been unable to explain them. In a CAABA

797 box model, MECCA chemistry predicts efficient activation of particulate $\mathrm{Br}^{-}$in all aerosol

798 size fractions (e.g., Keene et al., 2009) and, thus, no significant Br enrichment of marine

799 aerosol within the MBL. Our 3-D model calculations suggest that the detrainment of

800 relatively insoluble forms of $\mathrm{Br}_{\mathrm{t}}$ from the MBL into the FT, chemical processing within the

801 FT, and the subsequent transport and entrainment of condensed or condensable reaction

802 products back into the MBL accounts for the Br enrichment of sub- $\mu \mathrm{m}$ aerosol size fractions

803 measured in the MBL. While Br is continuously cycled through the aerosol population even

804 in low LWC environments, the equilibration with $\mathrm{HBr}(\mathrm{g})$ dominates the net $\mathrm{Br}$ exchange

805 leading to steady state enrichments of the smaller (yet more abundant at altitude) aerosols.

806 Both the zonal median $\mathrm{EF}(\mathrm{Br})$ for bulk aerosol in the model surface layer and available

807 measurements of $\mathrm{EF}(\mathrm{Br})$ (taken from Sander et al., 2003) indicate a slight NH latitudinal

808 gradient at high latitudes, which is more pronounced in the observations (Fig. 2). Sander et

809 al. (2003) suggest that the $\mathrm{EF}(\mathrm{Br})$ greater than unity in the $\mathrm{NH}$ may result from anthropogenic

$810 \mathrm{Br}$ emissions in the region (primarily the N. Sea and Scandinavia) leading to bulk

811 enrichments. While zonal averages are not directly comparable to individual observations,

812 the model suggests a stronger latitudinal trend in the SH. This is likely due to the strong

813 subsidence in the high latitudes, consistent with the hypothesized mechanism of fine aerosol

814 enrichment observed throughout the marine boundary layer. Sparse measurements in that

815 region provide limited information with which to evaluate the simulated pattern. 
816 Geographically and seasonally coincident comparisons between simulated and measured

$817 \mathrm{EF}(\mathrm{Br})$ for size-resolved marine aerosol indicate strong agreement (Fig 3e-h).

818 Comparison of simulated and observed $\mathrm{Br}_{\mathrm{t}}$ reveals a fairly consistent pattern of model 819 over-prediction. With the exception of the NE Atlantic adjacent to N. Africa, where the 820 agreement was good, the model over-predicted $\mathrm{Br}_{\mathrm{t}}$ by factors of 2 to 6 (Table 2). It is 821 recognized that MECCA tends to overestimate $\mathrm{Br}_{\mathrm{t}}$ as was the case in Keene et al. (2009)

822 where simulated $\mathrm{Br}_{\mathrm{t}}$ was high by a factor of about 3 relative to observations. It is important to 823 note that, with the exception of Hawaii, the geographic locations in Table 2 were coincident

824 with large gradients in $\mathrm{NO}_{\mathrm{x}}$ and $\mathrm{Br}_{\mathrm{t}}$. The relatively coarse model resolution in these regions

825 constrains the reliability of comparisons between observed and simulated values and 826 probably contributes to the divergence in results..

827 Observations using the OMI instrument aboard NASA's Aura satellite are capable of 828 constraining vertical abundances of $\mathrm{BrO}$ (reported as column abundances, $\mathrm{cm}^{-2}$ ). It is difficult 829 to partition observations into the contribution of $\mathrm{BrO}$ from different altitudes to the total 830 column abundance. Vertically integrated simulated $\mathrm{BrO}$ (Fig. 4) ranged from $0.011 \times 10^{13}$ to

$8314.9 \times 10^{13} \mathrm{~cm}^{-2}$ (consistent with von Glasow et al., 2004) over the simulated 10-year annually 832 averaged period. Median BrO column burdens were $0.56 \times 10^{13}, 0.97 \times 10^{13}$, and $0.58 \times 10^{13}$

$833 \mathrm{~cm}^{-2}$ for DJF, MAM, and JJA periods, respectively. Corresponding median PBL BrO mixing 834 ratios were 1.1, 2.3 and $1.5 \mathrm{pmol} \mathrm{mol}^{-1}$ for DJF, MAM and JJA, respectively. Median FT $835 \mathrm{BrO}$ was $0.15,0.20$ and $0.25 \mathrm{pmol} \mathrm{mol}^{-1}$ for DJF, MAM and JJA, respectively. Maximum 836 column integrated $\mathrm{BrO}$ for the MAM NH was $4.9 \times 10^{13} \mathrm{~cm}^{-2}$. An estimated tropospheric 837 maximum column burden of $3.9( \pm 2.5) \times 10^{13} \mathrm{~cm}^{-2}$ was computed based on aircraft-based 838 observed profiles (Salawitch et al., 2010). Typical NH spring-time peak total column burdens 839 measured by satellite exceed our maximum values by a factor of $\sim 2$ (e.g. Richter et al., 2002).

840 These peaks typically occur over the polar ice-caps and are believed to be due to "bromine 841 explosions" during Arctic springtime (Simpson et al., 2007; Piot and von Glasow, 2008).

842 While all hypothesized sources specific to the Arctic are not considered here, the results 843 depicted in Fig. 4 provide a potentially useful background values for estimating the 844 contribution to total $\mathrm{Br}$ from sources other than activation pathways involving marine aerosol 845 (e.g., reactions involving brine films on surfaces, frost flowers, organobromine precursors, 846 downwelling of stratospheric BrO, etc.).

847 A subset of available measurements of $\mathrm{BrO}$ in the MBL is compared with the 848 corresponding average values in Table 3. The model output mixing ratios are averaged over 
849 diel cycles. To estimate daytime mean mixing ratios from the diel averages, we assumed that

850 BrO mixing ratios dropped to zero at night and adopted the fraction of hours of daylight

851 appropriate for the time of year. Simulated daytime mixing ratios agreed with observations

852 within a factor of about 2 to 3 at all locations. The simulated BrO maxima in the tropical

853 Atlantic and Pacific MBL (Fig. 5b) have not been probed via direct measurement. But, as

854 was the case with simulated $\mathrm{Br}_{\mathrm{t}}$, circulation and the coarse model resolution constrain the

855 reliability of comparisons between measurements and simulated results in regions of strong

856 chemical gradients. For example, mean $\mathrm{BrO}$ in grid boxes immediately to the east of that

857 corresponding to Sao Vicente, Cape Verde were a factor of two lower than that reported in

858 Table 3.

859 Throughout most of the lower troposphere and boundary layer, the $\mathrm{BrO}+\mathrm{NO}$ reaction is

860 the largest source of atomic $\mathrm{Br}$ (Table 4). The exception is the southern MBL where $\mathrm{BrO}+$

$861 \mathrm{BrO}$, and $\mathrm{HOBr}$ and $\mathrm{Br}_{2}$ photolysis dominate. In the global free troposphere simulated atomic

$862 \mathrm{Br}$ originates primarily from $\mathrm{BrO}+\mathrm{NO}$ and $\mathrm{HOBr}$ photolysis in approximately equal

863 proportions. The dominant sources for simulated $\mathrm{HOBr}$ in the free troposphere are $\mathrm{BrO}+$

$864 \mathrm{HO}_{2}(84 \%)$ and $\mathrm{BrO}+\mathrm{CH}_{3} \mathrm{O}_{2}$ (16\%; primarily from $\mathrm{CH}_{4}$ oxidation). As the result of low

865 liquid water content, $\mathrm{Br}$ radicals in the free troposphere recycle primarily in the gas phase;

866 though as discussed above, heterogeneous recycling is also important.

\subsubsection{Cl Distributions}

869 Simulated $\mathrm{HCl}$ mixing ratios are high in comparison with available measurements in the

870 MBL. For example, Pszenny et al. (2003) measured $\mathrm{HCl}$ ranging from <30 to $250 \mathrm{pmol} \mathrm{mol}^{-1}$

871 (mean, $100 \mathrm{pmol} \mathrm{mol}^{-1}$ ) in on-shore flow within the Hawaiian MBL, compared to a simulated

872 surface median of 1247 (1046 to 1383) $\mathrm{pmol} \mathrm{mol}^{-1}$. The simulated values were driven by in

873 situ acidification of marine aerosol by high volcanic $\mathrm{SO}_{2}$ emissions which were emitted at the

874 model surface. For comparison, simulated $\mathrm{HCl}$ upwind of the volcanic $\mathrm{SO}_{2}$ plume was more

875 than a factor of two lower. $\mathrm{HCl}$ measured along a transect in the E. Atlantic MBL was 682

876 (106 to 1404) $\mathrm{pmol} \mathrm{mol}^{-1}$ in the vicinity of the European continent, 348 (91 to 746) $\mathrm{pmol} \mathrm{mol}^{-}$

$877{ }^{1}$ adjacent to $\mathrm{N}$. Africa, $82\left(<23\right.$ to 207) $\mathrm{pmol} \mathrm{mol}^{-1}$ in the Intertropical Convergence Zone,

878 and 267 (81 to 453) pmol mol ${ }^{-1}$ adjacent to S. Africa (Keene et al., 2009). Corresponding

879 simulated median surface $\mathrm{HCl}$ mixing ratios for these regions were 352 (8 to 1577), 906 (271

880 to 1914 ), 424 (294 to 697 ), and 445 (0.11 to 3155$) \mathrm{pmol} \mathrm{mol}^{-1}$, respectively. Maximum $\mathrm{HCl}$

881 mixing ratios in the E. Atlantic were generally coincident with acid-displacement reactions 
882 involving $\mathrm{HNO}_{3}$ in marine regions downwind of major $\mathrm{NO}_{\mathrm{x}}$ emission sources. As for $\mathrm{Br}_{\mathrm{t}}$, the

883 strong gradients along the cruise track constrain the reliability of comparisons between

884 measured and simulated $\mathrm{HCl}$.

885 Differences between aerosol $\mathrm{pH}$ in $\mathrm{Hal}$ versus $\mathrm{NoHal}$ simulations reflect the influence of

$886 \mathrm{HCl}$ phase partitioning on aerosol solution acidity in the former versus lack thereof in the

887 latter (not shown). Acid displacement of $\mathrm{HCl}$ by $\mathrm{HNO}_{3}$ and other relatively more soluble

888 acids transfers acidity from the aerosol solution to the gas phase and thereby sustains higher

889 solution pHs in the $\mathrm{Hal}$ simulation (e.g., Keene et al., 1998). For all locations at which

890 published estimates of aerosol $\mathrm{pH}$ based on in situ observations were available, simulated

$891 \mathrm{pHs}$ based on Hal compared better with those estimates than did pHs based on NoHal (not

892 shown; also see Keene et al., 2009).

893 Simulated $\mathrm{Cl}^{*}$ mixing ratios in the PBL are higher over much of the NH high-latitudes,

894 relative to other regions, with peak values in marine-influenced air downwind of major

895 population and industrial regions. This is due to interactions with high anthropogenic $\mathrm{NO}_{\mathrm{x}}$

896 emissions (see Section 3.3.3). Simulated $\mathrm{Cl}^{*}$ in the SH-MBL (ranging from less than 0.01 to

$897340 \mathrm{pmol} \mathrm{mol}^{-1}$, median $27 \mathrm{pmol} \mathrm{mol}^{-1}$ ) was comprised of $46 \%, 16 \%, 6 \%$ and $1 \% \mathrm{BrCl} \mathrm{Cl}_{2}$

898 (on a molecular basis), $\mathrm{HOCl}$, and $\mathrm{ClNO}_{2}$, respectively, based on median values. $\mathrm{Cl}^{*}$ in the

$899 \mathrm{NH}$ MBL was comprised of $20 \%, 29 \%, 3 \%$ and $10 \% \mathrm{BrCl}_{1} \mathrm{Cl}_{2}, \mathrm{HOCl}$, and $\mathrm{ClNO}_{2}$,

900 respectively, based on median values. In contrast, over $\mathrm{NH}$ continents, $\mathrm{ClNO}_{2}$ made up $69 \%$

901 of $\mathrm{Cl}^{*}$ and was higher than $\mathrm{ClNO}_{2}$ in the $\mathrm{NH}-\mathrm{MBL}$ by a factor of 10 (see Supplemental Table

902 S4). This reflects the differences in $\mathrm{NO}_{\mathrm{x}}$ loadings between both continental and marine

903 troposphere, and the southern and northern hemispheres. In the MECCA chemical

904 mechanism, $\mathrm{ClNO}_{2}$ is produced at night and subsequently photolyzes following sunrise via

$905 \quad \mathrm{~N}_{2} \mathrm{O}_{5}+\mathrm{Cl}^{-} \rightarrow \mathrm{ClNO}_{2}+\mathrm{NO}_{3}^{-}$

907 Significant production is limited to highly polluted conditions with $\mathrm{NO}_{\mathrm{x}}$ mixing ratios greater

908 than $\sim 1 \mathrm{nmol} \mathrm{mol}^{-1}$. There is some evidence of the importance of $\mathrm{ClNO}_{2}$ cycling over coastal

909 and continental regions (e.g. Ostoff et al., 2008, Simon et al. 2009, Thornton et al. 2010;

910 Phillips et al. 2012). Mean simulated $\mathrm{ClNO}_{2}$ mixing ratios in the summer time surface layer

911 adjacent to the U.S. Texas Gulf Coast were $134( \pm 51) \mathrm{pmol} \mathrm{mol}^{-1}$ and were consistent with

912 both observations made by Osthoff et al. (2008) and non-polluted simulation results (Simon

913 et al., 2009). Mean simulated $\mathrm{ClNO}_{2}$ mixing ratios for February at Boulder, $\mathrm{CO}$ USA $\left(40^{\circ} \mathrm{N}\right.$

$\left.914105^{\circ} \mathrm{W}\right)$ were $129( \pm 38) \mathrm{pmol} \mathrm{mol}^{-1}$, which is within the range of $\mathrm{ClNO}_{2}$ mixing ratios 
915 observed by Thornton et al. (2010) in this region (ranging from less than 1 to $210 \mathrm{pmol} \mathrm{mol}^{-}$

$916^{1}$ ). The simulated distribution of $\mathrm{ClNO}_{2}$ over N. America (Fig. 6) is also generally consistent

917 with production patterns based on the GEOS-Chem model (Thornton et al., 2010). $\mathrm{ClNO}_{2}$

918 mixing ratios simulated by Hal are generally higher and extend over broader geographic

919 regions downwind from continents relative those simulated by Erickson et al. (1999), and

920 compare well with limited observations. During a March-April 2008 cruise in the North

921 Atlantic, Kercher et al. (2009) report nighttime $\mathrm{ClNO}_{2}$ mixing ratios from 100 to 250 pmol

$922 \mathrm{~mol}^{-1}$ within the Long Island sound (coordinates not reported; assumed in the vicinity of

$\left.92341.5^{\circ} \mathrm{N}, 70^{\circ} \mathrm{W}\right)$, and at or near 25 to50 $\mathrm{pmol} \mathrm{mol}^{-1}$ further offshore $\left(45^{\circ} \mathrm{N}, 55^{\circ} \mathrm{W}\right)$. Simulated

$924 \mathrm{ClNO}_{2}$ mixing ratios within the corresponding grid cells, adjusted by a factor of two to

925 account for day length were $302( \pm 88.4) \mathrm{pmol} \mathrm{mol}^{-1}$ and $75.6( \pm 36.3) \mathrm{pmol} \mathrm{mol}^{-1}$,

926 respectively.. The broad distribution of $\mathrm{ClNO}_{2}$ in the high latitudes suggests that its transport

927 and cycling is important as a source for atomic $\mathrm{Cl}$ and a nocturnal reservoir for $\mathrm{NO}_{\mathrm{x}}$ in

928 polluted continental and marine regions.

929 Simulated atomic $\mathrm{Cl}$ in the global MBL ranged from 0 to $8.4 \times 10^{4} \mathrm{~cm}^{-3}$, which brackets

930 reported values inferred from measurements of NMHCs and $\mathrm{C}_{2} \mathrm{Cl}_{4}\left(0\right.$ to $\sim 10^{5} \mathrm{~cm}^{-3}$; Rudolph

931 et al, 1996, Singh et al, 1996). The simulated atomic $\mathrm{Cl}$ concentration of $2.6 \pm 1.5 \times 10^{4} \mathrm{~cm}^{-3}$ in

932 New England (USA) coast air during summer was within the corresponding range of

933 estimates based on relative concentration changes in NMHCs $\left(2 \times 10^{4}\right.$ to $6 \times 10^{4} \mathrm{~cm}^{-3}$;

934 Pszenny et al., 2007). An estimate of $3.3 \pm 1.1 \times 10^{4} \mathrm{~cm}^{-3}$ derived from measurements made

935 during a N. Atlantic cruise in June 1992 (Wingenter et al., 1996), was similar to a simulated

936 value of $4.8 \pm 1.6 \times 10^{4} \mathrm{~cm}^{-3}$ for the same region. Measurements in the southern ocean MBL

937 yielded estimated atomic $\mathrm{Cl}$ concentrations of $720 \pm 100 \mathrm{~cm}^{-3}$ which is a factor of two lower

938 than our simulated summertime surface mean of $2.0 \pm 1.6 \times 10^{3} \mathrm{~cm}^{-3}$ (Wingenter et al., 1999).

939 The ANN-SH-MBL median for simulated values $\left(3.5 \times 10^{3} \mathrm{~cm}^{-3}\right)$ was within the estimated

$9400.26 \times 10^{4}$ to $1.8 \times 10^{4} \mathrm{~cm}^{-3}$ required to sustain observed $\mathrm{CH}_{4}$ isotope ratios in the southern

941 MBL (Allan et al., 2001; Platt et al., 2004).

942 We note that, unless otherwise indicated, model output is based on monthly averages that

943 do not reflect daytime maxima; and thus peak mixing ratios for species produced

944 photochemically in ambient air are higher. In addition, the simulation did not consider non-

945 marine sources for $\mathrm{Cl}$ in the atmosphere and thus the total production fluxes and burdens of

$946 \mathrm{Cl}$ should be considered lower limits. 
950 Deviations between the $\mathrm{Hal}$ and $\mathrm{NoHal}$ simulations of zonally averaged surface $\mathrm{O}_{3}$ (Fig.

951 7) and the corresponding zonal-median vertical distribution fields (see Supplemental Figure

$952 \mathrm{~S} 3$ ) reveal less $\mathrm{O}_{3}$ globally in the $\mathrm{Hal}$ simulation. These results are driven primarily by (1) the

953 direct destruction of $\mathrm{O}_{3}$ via reaction with halogen radicals (Table 5) and (2) the net reduction

954 in $\mathrm{O} 3$ production resulting from the accelerated oxidation of $\mathrm{NO}_{\mathrm{x}}$ via formation and

955 processing of halogen nitrates (discussed in more detail below; Sander et al., 1999; Pszenny

956 et al., 2004; Keene et al., 2009). The largest absolute deviations were in the high latitudes and

957 generally coincident with relatively greater direct destruction of $\mathrm{O}_{3}$ via reaction with atomic

$958 \mathrm{Br}$ and $\mathrm{NO}$ (Fig. 7c). The reduction of $\mathrm{NO}_{\mathrm{x}}$ and its influence on $\mathrm{O}_{3}$ was also significant in the

959 free troposphere with a similar latitudinal pattern (mean deviation of $-39 \%$; not shown).

960 These results are not consistent with those from previous studies in two respects. First, the

961 geographic distribution of $\mathrm{Br}$-mediated $\mathrm{O}_{3}$ loss is different. Our simulation yields maximum

962 impacts in high latitudes whereas other studies report that tropical regions are impacted to a

963 greater degree (e.g. Yang et al., 2005; Sais-Lopez et al., 2012). The causes for these

964 differences are not entirely clear. In our study, the negative ozone deviations in high-latitude

965 MBL and polar PBL are coincident with higher $\mathrm{NO}$ and lower $\mathrm{HO}_{2}$ concentrations (see

966 Section 3.3.2) relative to the $\mathrm{NoHal}$ simulations, which enhanced $\mathrm{O}_{3}$ destruction via the $\mathrm{NO}+$

$967 \mathrm{O}_{3}$ reaction path. In regions where NO abundance decreased from NoHal to Hal (e.g. in the

968 remote tropical MBL) the net $\mathrm{O}_{3}$ loss was also lower. Second, ozone loss is greater in our

969 simulations. Sais-Lopez et al. (2011) calculate net $\mathrm{O}_{3}$ loss due to halogens from 6 to $20 \%$ in

970 the tropical troposphere. Our results exceed $20 \%$ for most of the tropical MBL and are

971 around 15 to $20 \%$ for the tropical FT. It is not clear if Sais-Lopez et al. (2012) also consider

972 the indirect destruction of ozone via changes in $\mathrm{HO}_{\mathrm{x}} / \mathrm{NO}_{\mathrm{x}}$ abundance and partitioning.

973 In addition, the suppression of $\mathrm{RO}_{2}$ production by $\mathrm{BrO}$ leads to a net decrease in $\mathrm{RO}_{2}$

974 mixing ratios in the PBL. This suppressed the reaction of $\mathrm{NO}+\mathrm{RO}_{2}$ globally by $38 \%$ and

$97549 \%$ in the PBL and FT, respectively, thereby contributing to net $\mathrm{O}_{3}$ destruction.

$976 \mathrm{O}_{3}$ simulated with $\mathrm{Hal}$ and $\mathrm{NoHal}$ is compared with $\mathrm{O}_{3}$ measured in near surface air at

977 Hawaii during September (Pszenny et al, 2004) and along a transect through the E. Atlantic

978 during October and November (Keene et al. 2009) in Figure 9. In all cases, the Hal

979 simulations yielded $\mathrm{O}_{3}$ mixing ratios that were closer to those observed. 

(WOUDC) sites (Table 6) are compared to corresponding simulated $\mathrm{O}_{3}$ mixing ratios in the

$982 \mathrm{PBL}$ and in the FT at the $500 \mathrm{mb}$ pressure level in Fig. 10. Relative to mean mixing ratios measured in the PBL and 500mb levels, deviations in mean ( \pm standard deviation) $\mathrm{O}_{3}$

984 simulated with $\mathrm{Hal}$ were $-26 \%( \pm 21 \%)$ and $-27 \%( \pm 12 \%)$, respectively. Corresponding 985 deviations based on NoHal were $42 \%( \pm 25 \%)$ and $9.3 \%( \pm 15 \%)$, respectively. For the PBL, 986 although the correlation coefficient for $\mathrm{O} 3$ based on $\mathrm{NoHal}$ was higher, the Hal simulations 987 better reproduce observed $\mathrm{O}_{3}$ for nearly all stations (Fig. 10). Relative to $\mathrm{Hal}$, or $\mathrm{O}_{3}$ at the $988500 \mathrm{mb}$ level simulated with $\mathrm{NoHal}$ were closer to observed $\mathrm{O}_{3}$ mixing ratios.

\subsubsection{OH: $\mathrm{HO}_{2}$}

991 Median $\mathrm{OH}$ and $\mathrm{HO}_{2}$ mixing ratios in the PBL simulated with $\mathrm{Hal}$ were lower by $41 \%$ and $99218 \%$, respectively, relative to NoHal. Differences were greatest in the MBL and resulted 993 primarily from three processes. First, the enhancement of $\mathrm{NO}+\mathrm{HO}_{2}$ and the addition of $\mathrm{BrO}$ $994+\mathrm{HO}_{2} \rightarrow \mathrm{HOBr}+\mathrm{O}_{2}$ (and subsequent uptake of $\mathrm{HOBr}$ by liquid aerosol) are $\mathrm{HO}_{2}$ sinks. $995 \mathrm{HOBr}$ uptake by aerosols in the MBL was approximately equivalent to $\mathrm{OH}$ recycling via $996 \mathrm{HOBr}$ photolysis. Second, the accelerated rate of $\mathrm{NO}_{2}$ oxidation by halogen species (section 997 3.3.3) reduced the production of $\mathrm{HO}_{2}$. In combination with increased $\mathrm{NO}$ in the vicinity of 998 high $\mathrm{HO}_{2}$ mixing ratios and lower $\mathrm{O}_{3}$, this led to a net decrease in both $\mathrm{OH}$ and $\mathrm{HO}_{2}$. Third, 999 globally less $\mathrm{O}_{3}$ reduced the photochemical production of $\mathrm{O}\left({ }^{1} \mathrm{D}\right)$. Overall, the $\mathrm{OH}: \mathrm{HO}_{2}$ ratio 1000 decreased 28\%, consistent with Keene et al. 2009 (3\% to 32\% decrease).

1001

1002 3.3.3 $\mathrm{NO}_{\mathrm{x}}$

1003 The cycling of $\mathrm{Cl}$ and $\mathrm{Br}$ in the $\mathrm{Hal}$ simulations impacted distribution, speciation, and 1004 lifetimes of $\mathrm{NO}_{x}$ species in two ways. Under polluted conditions at night, $\mathrm{N}_{2} \mathrm{O}_{5}$ is produced 1005 from

$$
\begin{aligned}
& \mathrm{NO}_{2(\mathrm{~g})}+\mathrm{O}_{3(\mathrm{~g})} \rightarrow \mathrm{NO}_{3(\mathrm{~g})}+\mathrm{O}_{2(\mathrm{~g})} \\
& \mathrm{NO}_{3(\mathrm{~g})}+\mathrm{NO}_{2(\mathrm{~g})} \leftrightarrow \mathrm{N}_{2} \mathrm{O}_{5(\mathrm{~g})}
\end{aligned}
$$

1008 Some $\mathrm{N}_{2} \mathrm{O}_{5}$ reacts with particulate $\mathrm{Cl}^{-}$to produce $\mathrm{ClNO}_{2}$ via $\mathrm{R}$. In addition, $\mathrm{N}_{2} \mathrm{O}_{5}$ also 1009 hydrolyzes to produce $\mathrm{HNO}_{3}$, which accounts for $30 \%$ to $50 \%$ of the total $\mathrm{NO}_{\mathrm{x}}$ sink in 1010 polluted regions (Alexander et al., 2009). The photolysis of $\mathrm{ClNO}_{2}$ following sunrise via $\mathrm{R} 10$ 1011 regenerates half the $\mathrm{NO}_{2}$ from which the precursor $\mathrm{N}_{2} \mathrm{O}_{5}$ was formed and also produces 
1012 highly reactive $\mathrm{Cl}$ atoms. Thus, this pathway acts as both a source for halogen radicals and a

1013 nocturnal reservoir for $\mathrm{NO}_{\mathrm{x}}$ that efficiently extends its atmospheric lifetime and thereby

1014 enhancing $\mathrm{O}_{3}$ production relative to that predicted in the absence of $\mathrm{R} 9$ and $\mathrm{R} 10$ (as in

$1015 \mathrm{NoHal})$. Figure 11a depicts the percent deviation of $\mathrm{NO}_{\mathrm{x}}\left(\mathrm{NO}+\mathrm{NO}_{2}\right)$ in the PBL for Hal

1016 versus $\mathrm{NoHal}$ simulations. The increased $\mathrm{NO}_{\mathrm{x}}$ lifetime resulting primarily from $\mathrm{ClNO}_{2}$

1017 production and processing is evident in the positive deviations along the primary transport

1018 pathways downwind of major pollution sources.

1019 Under clearer conditions in the MBL, the formation and subsequent hydrolysis of halogen 1020 nitrates via

$$
\mathrm{NO}_{2}+\mathrm{ClO} \rightarrow \mathrm{ClNO}_{3}
$$

$$
\mathrm{ClNO}_{3}+\mathrm{H}_{2} \mathrm{O}(\mathrm{l}) \rightarrow \mathrm{HOCl}+\mathrm{HNO}_{3}
$$

1024 1999; Pszenny et al., 2004; Keene et al., 2009). The influence of these reactions is evident in 1025 the negative deviations in $\mathrm{NO}_{\mathrm{x}}$ simulated by $\mathrm{Hal}$ relative to $\mathrm{NoHal}$ for much of the global 1026 MBL (Fig. 11a) and in differences in median $\mathrm{NO}_{\mathrm{x}}$ mixing ratios simulated with Hal versus 1027 NoHal for the NH MBL, SH MBL, and PBL. As noted above, the accelerated oxidation of $1028 \mathrm{NO}_{\mathrm{x}}$ via these pathways impacts oxidation processes through net $\mathrm{O}_{3}$ and $\mathrm{OH}$ destruction and 1029 modified $\mathrm{OH} / \mathrm{HO}_{2}$ ratios. In the Antarctic region, the presence of increased $\mathrm{Br}$, and less $\mathrm{O}_{3}$ 1030 and $\mathrm{HO}_{\mathrm{x}}$ increased the lifetime of $\mathrm{NO}$ leading to a positive $\mathrm{NO}$ deviation while $\mathrm{NO}_{2}$ 1031 decreases (Fig. 11b \& c).

\subsection{Impact of Halogens on S Cycling}

1034 In general, the global-scale sources, lifetimes, and sinks for major S species compare well 1035 with the modal-CAM standard chemical scheme and other global model studies of the S 1036 budget (Table 7). Major differences between MECCA and modal-CAM are driven in part by 1037 influences of halogens in the oxidation of $\mathrm{DMS}$ and $\mathrm{SO}_{2}$, lower $\mathrm{OH}$ concentrations in the 1038 PBL in MECCA-CAM, and differences in the treatment of $\mathrm{H}_{2} \mathrm{SO}_{4}$.

1039 The primary DMS oxidation pathways in the conventional mechanism considered in most 1040 models are reaction with $\mathrm{OH}$ during daytime and reaction with $\mathrm{NO}_{3}$ at night. DMS burden 1041 and lifetime in $\mathrm{NoHal}$ are about five times that in the standard modal-CAM, due to lower $\mathrm{OH}$ 1042 and $\mathrm{NO}_{3}$ concentrations (factor of 2 to 3 for both) in the global PBL. The Hal and NoHal 1043 simulations calculate $\mathrm{OH}$ online while standard modal-CAM uses an offline oxidant database 
1044 of monthly averages taken from simulations by a chemistry-climate model (Lamarque et al., 1045 2010).

1046 Oxidation of DMS by BrO has been proposed as an important alternate pathway (Toumi, 1047 1994; von Glasow, 2002) and oxidation by atomic Cl may also be significant at high Cl-atom 1048 concentrations (Keene et al., 1996). Comparison of the major DMS reaction pathways is 1049 presented in Table 8. Hal simulations indicate that reaction with $\mathrm{BrO}$ is important throughout 1050 the whole atmosphere, and responsible for $84 \%$ of all DMS oxidation in the southern 1051 hemisphere MBL. Comparing the total oxidation rate shows that DMS is oxidized faster 1052 globally (Table 8, factor of 1.40 in the PBL) than would be predicted by the reaction with $\mathrm{OH}$ 1053 and $\mathrm{NO}_{3}$ alone. Globally, median DMS mixing ratios were lower by $74 \%$ and $89 \%$ in the 1054 PBL and FT, respectively. The greatest differences in DMS mixing ratios were coincident 1055 with emissions patterns in the SH MBL (Fig. 13c), reflecting the faster oxidation in the Hal 1056 simulations. Positive DMS deviations were coincident with low relative mixing ratios.

1057 The $\mathrm{SO}_{2}$ budgets for the $\mathrm{Hal}$ and $\mathrm{NoHal}$ simulations are quite similar. In comparison to 1058 the standard modal-CAM, the main difference is the lower gas-phase oxidation due to lower 1059 PBL OH concentration in MECCA-CAM, and slower aqueous uptake. In both $\mathrm{Hal}$ and $1060 \mathrm{NoHal}$ simulations, oxidation by $\mathrm{H}_{2} \mathrm{O}_{2}$ in the cloud water aqueous phase was the single most 1061 important sink for $\mathrm{SO}_{2}$ globally (Table 8). In the Hal simulation, oxidation of $\mathrm{S}(\mathrm{IV})$ in 1062 deliquesced aerosols accounted for about $12 \%$ of S(IV) oxidation in the SH MBL, but only $10631 \%$ globally. Aqueous-phase pathways for S(IV) oxidation in aerosol solutions are strongly 1064 pH dependent (Chameides and Stelson, 1992; Keene et al., 1998). For size fractions that 1065 overlap, simulated aerosol pH's based on $\mathrm{Hal}$ are reasonably representative of available 1066 estimates inferred from direct measurements (Fig. 3). The mediation of pH by acid1067 displacement in the $\mathrm{Hal}$ simulation resulted in a much greater uptake of $\mathrm{SO}_{2}$ in aerosol (Fig. 1068 13b). $\mathrm{SO}_{2}$ (g) and aerosol S(IV) simulated for the ANN-PBL by Hal versus NoHal (Fig. 13a, 1069 b) diverged by median values of $-7.73 \%(-77.4 \%$ to $686 \%)$ and $428 \%(-99.9 \%$ to $1.87 \mathrm{x}$

$107010^{7} \%$ ), respectively. These differences are driven primarily by the absence of acid-

1071 displacement reactions involving $\mathrm{HCl}$ and the associated low aerosol solution pHs (by 1 to 2 1072 units) in NoHal. Significant aqueous-phase oxidation of $\mathrm{S}(\mathrm{IV})$ by $\mathrm{O}_{3}$ in aerosol solutions is 1073 limited to alkaline conditions (Chameides and Stelson, 1992) and, consequently, this pathway 1074 was important only in the SH where persistent high winds sustain high concentrations of 1075 marine aerosol (Long et al., 2011), sources of acidity are relatively low, and, thus pH values 1076 are relatively high (see Supplement). The lower $\mathrm{pH}$ of aerosol solutions in other regions 
1077 efficiently suppressed aerosol S(IV) oxidation by $\mathrm{O}_{3}$ in $\mathrm{Hal}$ simulations (Table 8). Aqueous-

1078 phase oxidation of $\mathrm{S}(\mathrm{IV})$ by $\mathrm{HOCl}$ and $\mathrm{HOBr}$ enhances production of $\mathrm{S}(\mathrm{VI})$ in moderately

1079 acidic (pH 5 to 6 aerosol solutions; Vogt et al., 1996; Keene et al., 1998; von Glasow et al.,

1080 2002) but production via these pathways decreases with decreasing $\mathrm{pH}$ due to the lower

1081 solubility of $\mathrm{SO}_{2}$ (Keene et al., 2009). As noted above, aerosol pH values simulated by $\mathrm{Hal}$

1082 are reasonably consistent with those derived from observations. The $\mathrm{pH}$ range of 5 to 6 is

1083 transient and, in most regions, acidified aerosols rapidly equilibrate with atmospheric acids at

1084 somewhat lower pHs. Consequently, Hal simulations indicate oxidation of S(IV) by

1085 hypohalous acids accounts for minor to negligible fractions of S(IV) oxidation in the MBL

1086 globally (Table 8). Differences in our results compared to von Glasow et al. (2002) were due

1087 to the inability to differentiate between cloudy and non-cloudy conditions in our monthly-

1088 mean model datasets, whereas von Glasow et al. (2002) were able to explicitly differentiate

1089 processes under clear-sky and cloudy conditions.

1090 The most noticeable budget differences between CAM/MECCA and the standard modal-

$1091 \mathrm{CAM}$ are for $\mathrm{H}_{2} \mathrm{SO}_{4}$ vapor. In $\mathrm{Hal}$ and $\mathrm{NoHal}$, the $\mathrm{H}_{2} \mathrm{SO}_{4}$ source (from $\mathrm{SO}_{2}$ reaction with

$1092 \mathrm{OH}$ ) is smaller but the burden and lifetime are higher, which was driven by several factors.

1093 First, the lower PBL OH concentrations in $\mathrm{Hal}$ and $\mathrm{NoHal}$ result in more $\mathrm{SO}_{2}$ being mixed

1094 into the FT where the total aerosol surface area and liquid water content are low and

$1095 \mathrm{H}_{2} \mathrm{SO}_{4}(\mathrm{~g})$ loss by condensation is relatively slow resulting in higher burdens and lifetimes.

1096 Modal-CAM calculates $\mathrm{H}_{2} \mathrm{SO}_{4}$ vapor production (by gas-phase chemistry) and uptake by

1097 aerosols sequentially, while $\mathrm{Hal}$ and NoHal calculate them simultaneously, which has been

1098 shown to affect $\mathrm{H}_{2} \mathrm{SO}_{4}$ vapor concentrations (Kokkola et al., 2009). In addition, modal-CAM

1099 uses the Fuchs-Sutugin equation to calculate $\mathrm{H}_{2} \mathrm{SO}_{4}$ mass-transfer rates from gas to particle

1100 phases, whereas $\mathrm{Hal}$ and NoHal use the method of Schwartz (1986), yielding mass-transfer

1101 rates generally slower in $\mathrm{Hal}$ and $\mathrm{NoHal}$ than in modal-CAM (Sander, 1999). A more

1102 detailed evaluation of differences in the simulated $\mathrm{H}_{2} \mathrm{SO}_{4}$ vapor concentrations is beyond the

1103 scope of this study. The higher $\mathrm{H}_{2} \mathrm{SO}_{4}(\mathrm{~g})$ concentrations in the FT also lead to higher rates of

1104 nucleation and growth of new particles in $\mathrm{Hal}$ and $\mathrm{NoHal}$. Particle number concentrations

1105 based on enhanced nucleation in Hal yielded reasonably good agreement with observations

1106 from a wide range of locations (Table 9), while other studies report underestimations of

1107 concentrations under similar conditions (Adams and Seinfeld, 2002; Spracklen et al., 2005).

1108 These differences are important to aerosol microphysics in the FT, and thus deserve further 
1109 investigation. However, they do not significantly impact the budget or distribution of nss$1110 \mathrm{SO}_{4}{ }^{2-}$ in the simulations.

1111 The global nss- $\mathrm{SO}_{4}{ }^{2-}$ budgets for $\mathrm{Hal}$ and $\mathrm{NoHal}$ were nearly indistinguishable, while 1112 compared to a 5-year simulation of the standard modal-CAM, the nss- $\mathrm{SO}_{4}{ }^{2-}$ burden and 1113 lifetimes were $30 \%$ to $40 \%$ higher (Table 7). Globally, nss- $\mathrm{SO}_{4}{ }^{2-}$ shifted to smaller size bins 1114 driven by transport and subsequent oxidation of $\mathrm{SO}_{2}$ from the PBL into the FT in the CAM-

1115 MECCA system versus standard modal-CAM. While the Hal and NoHal global S budgets are 1116 close, there are regional differences approaching $\pm 30 \%$ for PBL concentrations. In the NH 1117 PBL, nss-SO ${ }_{4}{ }^{2-}$ was generally higher in $\mathrm{Hal}$ (Fig. 12d) due to enhanced gas-phase and 1118 aqueous-aerosol oxidation of $\mathrm{SO}_{2}$ (Fig. 12b), less oxidation in cloud droplets, and the shorter 1119 lifetime of nss- $\mathrm{SO}_{4}{ }^{2-}$ produced in cloud droplets. Lower nss-SO ${ }_{4}{ }^{2-}$ in the Indian and SE Asian 1120 PBL was driven in part by an $\sim 10 \%$ increase rain and wet removal. Effects of interactions 1121 between chemistry, weather and climate will be addressed in a subsequent paper. The largest 1122 relative (Fig. 12d) and absolute (not shown) nss-SO ${ }_{4}^{2-}$ positive deviations occurred 1123 immediately downwind of large anthropogenic sources of $\mathrm{SO}_{2}$ in eastern. China and the 1124 eastern USA. This was due to higher aerosol $\mathrm{pH}$ leading to more $\mathrm{SO}_{2}$ uptake (Fig. 12a \& b).

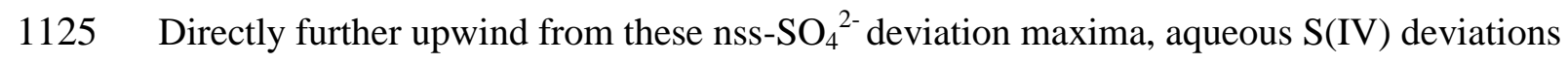
1126 become negative, indicating enhanced oxidation of S(IV) by aqueous halogen radicals (HOCl 1127 and $\mathrm{HOBr}$ ). In addition, a significant positive global correlation between nss- $\mathrm{SO}_{4}{ }^{2-}$ and 1128 aerosol liquid water $\left(\mathrm{R}^{2}=0.55 ; \mathrm{p}<0.01\right)$ in the PBL suggests a non-linear positive feedback 1129 link between aerosol hygroscopicity and its ability to take up and oxidize $\mathrm{SO}_{2}$ in the aqueous 1130 phase. In the $\mathrm{SH}$, the nss- $\mathrm{SO}_{4}{ }^{2-}$ burden decreased by $19 \%$ on average, due to faster gas-phase 1131 oxidation of DMS (primarily by $\mathrm{BrO}$ ) and somewhat lower yield of $\mathrm{SO}_{2}$, more efficient 1132 uptake of $\mathrm{SO}_{2}$ in larger aerosol particles with higher $\mathrm{pH}$, and faster deposition of the nss$1133 \mathrm{SO}_{4}{ }^{2-}$ formed in the larger particles (see Tables 7 and 8). Based on comparisons with 1134 observations, $\mathrm{Hal}$ and $\mathrm{NoHal}$ provided similar resolution in predicting mean annual $\mathrm{SO}_{2}$ and 1135 nss-SO $_{4}{ }^{2-}$ (Fig. 13, Table 10).

1136 Relative to the conventional pathways considered in NoHal and most other models, the 1137 net global effects of halogen chemistry on S cycling in marine air are accelerated oxidation of 1138 DMS thereby reducing its atmospheric lifetime. Despite relatively large influences on some 1139 pathways in the marine S cycle (Table 7), the domination of S cycling by continental and 1140 anthropogenically influenced air masses (where halogen chemistry is relatively less 1141 important) and by non-halogen aqueous chemistry in clouds limited the overall net effect of 
1142 halogens on the atmospheric S budget . However, simulated results suggest potential non-

1143 linear feedbacks that may significantly alter nss- $\mathrm{SO}_{4}{ }^{2-}$ distributions downwind of major

1144 sources.

$1146 \quad 3.5$ Halogen Interactions $\mathrm{NMHC}, \mathrm{CH}_{4}$

1147 The oxidation of $\mathrm{CH}_{4}$ and NMHC's is the primary source of $\mathrm{O}_{3}$ in the troposphere through

1148 the production of organic peroxy-radicals that short-circuit the destruction of $\mathrm{O}_{3}$ by NO.

1149 Relative to the $\mathrm{NoHal}$, reactions involving halogens in $\mathrm{Hal}$ decreased the total rate of $\mathrm{CH}_{3} \mathrm{O}_{2}$

1150 formation by $9 \%$ and $13 \%$ in the $\mathrm{PBL}$ and $\mathrm{FT}$, respectively, and total $\mathrm{CH}_{3} \mathrm{O}_{2}$ destruction by

$11512 \%$ and $14 \%$ in the PBL and FT, respectively. These reactions resulted in lower steady-state

1152 mixing ratios of $\mathrm{CH}_{3} \mathrm{O}_{2}$ throughout most of the global troposphere (not shown). $\mathrm{CH}_{3} \mathrm{O}_{2}$ in the

1153 FT did not vary significantly between the two runs.

1154 Averaged globally, in combination with lower $\mathrm{OH}$ plus reaction with atomic $\mathrm{Cl}, \mathrm{CH}_{4}$

1155 oxidation rates decreased by $3 \%$ relative to the $\mathrm{NoHal}$ simulation. The corresponding

1156 oxidation rates in the continental and marine boundary layer were higher by $13 \%$ and $9 \%$,

1157 respectively, reflecting the production of atomic $\mathrm{Cl}$ in the lower atmosphere. While atomic $\mathrm{Cl}$

1158 mixing ratios were comparable to (sparse) inferred observations, simulated $\mathrm{CH}_{4}$ mixing ratios

1159 were fixed throughout the atmosphere. As such, these results are considered upper limits.

\section{Discussion}

1162 The study presented here compared simulated multiphase chemistry of the atmosphere 1163 based on chemical reactions involving inorganic $\mathrm{Cl}$ and $\mathrm{Br}$. Comparisons between the Hal 1164 and $\mathrm{NoHal}$ simulations demonstrate that a multiphase chemical mechanism is capable of 1165 reproducing major, and in some cases previously unresolved, characteristics of the aerosol 1166 and gas-phase chemical composition of the atmosphere including gas-phase $\mathrm{Cl}$ and $\mathrm{Br}$ 1167 species and aerosol pH. Further, this work suggests that much of the observed distribution 1168 and impact of halogens and related chemical cycling in the PBL and lower FT may be 1169 explained with sea-salt derived $\mathrm{Cl}$ and $\mathrm{Br}$ alone. Results also highlight the role of 1170 meteorology and circulation in observations of reactive halogens and aerosol composition.

1171 The reproduction of observed $\mathrm{EF}(\mathrm{Br})$ and $\mathrm{EF}(\mathrm{Cl})$, and the model's dependence upon 1172 interactions between the FT and PBL in the enrichment process strongly suggests (1) that 1173 halogen cycling is important in the FT, (2) that FT halogen cycling is tightly coupled with 1174 PBL chemistry, and (3) global-scale circulation and dynamics play a large role in the global 
1175 distribution, partitioning and impacts of inorganic $\mathrm{Cl}$ and $\mathrm{Br}$ species. The results also suggest

1176 that $\mathrm{SO}_{2}$ oxidation by $\mathrm{HOBr}$ and $\mathrm{HOCl}$ primarily in the FT plays a central role in this

1177 dynamic connection.

1178 Comparison with observations indicate the $\mathrm{Hal}$ simulations reproduced tropospheric $\mathrm{O}_{3}$ in

1179 the MBL with reasonable confidence, and that systematic biases in $\mathrm{O}_{3}$ simulated with

1180 conventional chemical schemes were directly and indirectly attributable to reactions

1181 involving halogens. Reactions involving halogens destroyed significant quantities of $\mathrm{O}_{3}$

1182 throughout the MBL and the global troposphere. These pathways included direct destruction

1183 via reaction with halogen radicals and the accelerated regional oxidation of $\mathrm{NO}_{\mathrm{x}}$ via the

1184 formation and processing of halogen nitrates. Hal simulations indicate that the formation and

1185 processing of $\mathrm{ClNO}_{2}$ in the polluted NH PBL increases the atmospheric lifetime and transport

1186 of $\mathrm{NO}_{\mathrm{x}}$, alters $\mathrm{NO} / \mathrm{NO}_{2}$ partitioning; and activates significant atomic $\mathrm{Cl}$ with associated

1187 implication for oxidation processes.

$1188 \mathrm{Nss}_{-} \mathrm{SO}_{4}{ }^{2-}$ lifetimes were extended immediately downwind of major sources of $\mathrm{SO}_{2}$ due to

1189 the enhanced uptake of $\mathrm{SO}_{2}$ by higher $\mathrm{pH}$ aerosol in the Hal simulation versus NoHal. The

1190 oxidation DMS and to a lesser extent S(IV) by halogens in the MBL significantly modified

1191 regional S cycling relative to that based on conventional chemical pathways considered in

1192 most models. DMS oxidation was enhanced by the reaction with $\mathrm{BrO}$ and $\mathrm{Cl}$, accounting for

$119360 \%$ of DMS oxidation throughout the entire troposphere. In the Hal simulation, reactions in

1194 aqueous aerosol particles accounted for $12 \%$ of the total S(IV) oxidation in the SH MBL, but

1195 only about $1 \%$ globally. Reaction with $\mathrm{HOCl}$ and $\mathrm{HOBr}$ in moderately acidic aerosol

1196 solutions increased S(IV) oxidation rates in the PBL by only $1.2 \%$. Overall, halogen

1197 chemistry increased rates of S(VI) production from precursors.

1198 Systematic differences in $\mathrm{Br}_{\mathrm{t}}$ and $\mathrm{Br}$ species suggest a high sensitivity of the chemical

1199 system driven by these simulations to multiphase exchange of soluble gas-phase species. It is

1200 important to note that published values of Henry's Law constants $\left(\mathrm{K}_{\mathrm{H}}\right)$ of several species

1201 governing gas/aerosol partitioning vary by large amounts. Published values $\mathrm{K}_{\mathrm{H}}$ 's for $\mathrm{Br}_{2}$,

$1202 \mathrm{BrCl}$ and $\mathrm{HBr}$ all vary by factors of two or greater (see http:// www.henrys-law.org for a

1203 detailed discussion and compilation of Henry's Law constants).

1204 Major influences of halogen cycling on radiation, precipitation, and related climate

1205 processes will be evaluated in detail in a follow-up manuscript. The results presented here

1206 have important implications for feedbacks between the atmospheric chemistry and climate

1207 system and anthropogenically forced changes in atmospheric composition. The continued 
1208 expansion of the human population and global-scale industrialization will certainly result in 1209 increased emissions of acids and acid precursors. The results herein suggest that throughout 1210 most of the unpolluted southern hemisphere, halogen radical chemistry is already important.

1211 The increased acidification of marine aerosol in this region would lead to increased activation 1212 of halogen species with associated implications. It has been hypothesized that, at $\mathrm{pH}$ levels 1213 observed in the remote marine atmosphere, modest increases in acidity in this region would 1214 yield disproportionately large increases in $\mathrm{Cl}$ and $\mathrm{Br}$ activation rates (Sander et al., 2003).

1215 This study suggests that large-scale changes in halogen activation at the surface would 1216 impact the entire troposphere. The long-term implications of increased activation, though, 1217 cannot be assessed in the with short-term simulation studies such as this.

1218 In addition, current projections indicate that climate change will alter global and regional 1219 wind fields. Since marine aerosol production scales exponentially with wind speed, such 1220 changes would have major consequences for the production, atmospheric concentrations, and 1221 processing of marine aerosol.. Although the feedbacks cannot be assessed directly from this 1222 study, our results suggest that they would be significant. For example, in most regions, the 1223 larger size fractions that dominate production fluxes of marine aerosol mass are significantly 1224 debrominated during their atmospheric lifetime (e.g., Keene et al., 2009). Consequently, in 1225 MBL regions with sufficient acidity to titrate marine-derived alkalinity, available evidence 1226 suggests that enhanced wind-driven production of marine aerosols will lead to more vigorous 1227 Br-radical chemistry and associated feedbacks on tropospheric composition. Lastly, inorganic $1228 \mathrm{Br}$ is believed to be a primary $\mathrm{Hg}$ oxidant in the atmosphere and may control $\mathrm{Hg}$ 's 1229 atmospheric lifetime and deposition (Holmes et al., 2010). Large-scale emission of $\mathrm{Hg}$ to the 1230 atmosphere in South America associated with artisanal gold mining, combined with the 1231 potential for accelerated release of reactive Br into the Southern Hemisphere due to 1232 industrialization could pose a significant regional- to global-scale hazard.

1233 Future research to address these issues would require the capacity to run century-scale 1234 simulations using a fully-coupled (with an ocean model) configuration. To this end, the 1235 computational limitations of the system used here are prohibitively large. Additional effort is 1236 needed to increase the efficiency of the chemical solution and improve the capacity to store 1237 data.

1238 Still, several immediate research questions are apparent. Available evidence suggests that 1239 the production and processing of some compounds that are not considered in the current 1240 chemical mechanism are or may be import in atmospheric chemistry. These include (1) 
1241 organic $\mathrm{Cl}^{-}$and $\mathrm{Br}^{-}$containing compounds that are hypothesized to be the major sources of

1242 halogen radicals to the upper troposphere and stratosphere (see Sander et al., 2003 and

1243 references therein) and (2) iodocarbons and perhaps $I_{2}$ that are emitted from the ocean surface

1244 and significantly impact photochemistry and redox cycles in the MBL (Read et al., 2008;

1245 Sais-Lopez et al., 2011). Finally, large uncertainties in the parameterization of transfer

1246 coefficients and thermodynamic properties of some compounds (e.g., Henry's Law constants

1247 for Br species) must be resolved to improve our current understanding of and ability to

1248 reliably simulate multiphase processes.

5. References

1251 Adams, P. J., and J. H. Seinfeld, Predicting global aerosol size distributions in general

1252 circulation models, J. Geophys. Res., 107(D19), 4370, doi:10.1029/2001JD001010, 2002.

1253 Alexander, B., Hastings, M. G., Allman, D. J., Dachs, J.: Thornton, J. A., and Kunasek, S. A.,

1254 Quantifying atmospheric nitrate formation pathways based on a global model of the

1255 oxygen isotopic composition $\left(\Delta^{17} \mathrm{O}\right)$ of atmospheric nitrate, Atmos. Chem. Phys., 9, 5043-

1256 5056, doi:10.5194/acp-9-5043-2009, 2009.

1257 Allan, W., Lowe, D. C., and Cainey, J. M.: Active chlorine in the remote marine boundary

1258 layer: Modeling anomalous measurements of d13C in methane, Geophys. Res. Lett., 28, $1259 \quad 3239-3242,2011$.

1260 Andreae, M. O., and Rosenfeld, D.: Aerosol-cloud-precipitation interactions. Part 1. The

1261 nature and sources of cloud-active aerosols, Earth Science Reviews 89, 13-41, 2008.

1262 Anastasio, C., and Newberg, J. T.: Sources and sinks of hydroxyl radical in sea-salt particles.

1263 J. Geophys. Res., 112, D10306, doi:10.1029/2006JD008061, 2007..

1264 Birmili, W., Wiedensohler, A., Heintzenberg, J., and Lehmann, K.: Atmospheric particle

1265 number size distribution in central Europe: Statistical relations to air masses and

1266 meteorology, J. Geophys. Res.-Atmos., 106, 32 005-32 018, 2001.

1267 Boville, B. A., Rasch, P. J., Hack, J. J., and McCaa, J. R.: Representation of clouds and

1268 precipitation processes in the Community Atmosphere Model Version 3 (CAM3). J.

1269 Climate, 19(11), 2184-2198, 2006.

1270 Briegleb, B.P., Hunke, E.C., Bitz, C.M., Lipscomb, W.H., Holland, M.M., Schramm, J.L.,

1271 Moritz, R.E.: The sea ice simulation of the Community Climate System Model, version 2.

1272 Nat. Center for Atm. Res. Tech Rep no. NCAR-TN-455, Boulder, CO, 34pp, 2004. 
1273 Chameides, W. L., and Stelson, A. W.: Aqueous-phase chemical processes in deliquescent

1274 sea-salt aerosols: A mechanism that couples the atmospheric cycles of S and sea salt, J.

1275 Geophys. Res., 97, 20,565-20,580, 1992.

1276 Clarke, A. D., Owens, S. R., and Zhou, J.: An ultrafine sea salt flux from breaking waves:

1277 Implications for cloud condensation nuclei in the remote marine atmosphere, J. Geophys.

1278 Res., 111, D06202, doi:10.1029/2005JD006565, 2006.

1279 Dentener, F., Kinne, S., Bond, T., Boucher, O., Cofala, J., Generoso, S., Ginoux, P., Gong,

1280 S., Hoelzemann, J., Ito, A., Marelli, L., Penner, J., Putaud, J.-P., Textor, C., Schulz, M.,

1281 Werf, G.v.d., and Wilson, J.: Emissions of primary aerosol and precursor gases in the

1282 years 2000 and 1750 -prescribed data-sets for AeroCom, Atmos. Chem. Phys., 6, 4321-

$1283 \quad 4344,2006$.

1284 Dickerson, R. R., K. P. Rhoads, T. P. Carsey, S. J. Oltmans, J. P. Burrows, and P. J. Crutzen,

1285 Ozone in the remote marine boundary layer: A possible role for halogens, J. Geophys.

1286 Res., 104, 21385-21395, 1999.

1287 Dickinson, R.E., Oleson, K.W., Bonan, G.B., Hoffman, F., Thornton, P., Vertenstein, M.,

1288 Yang, Z.-L., Zeng, X.: The Community Land Model and it's cliamte statistics as a

1289 component of the Community Climate System Model. J. Clim., 19, 2302-2324, 2006.

1290 Erickson III, D. J., Seuzaret, C., Keene, W.C., and Gong, S.L.: A general circulation model

1291 based calculation of $\mathrm{HCl}$ and $\mathrm{ClNO}_{2}$ production from sea salt dechlorination: Reactive

1292 Chlorine Emissions Inventory, J. Geophys. Res., 104(D7), 8347-8372,

1293 doi:10.1029/98JD01384, 1999.

1294 Fitzenberger, R., Bösch, H., Camy - Peyret, C., Chipperfield, M.P., Harder, H., Platt, U.,

1295 Sinnhuber, B.-M., Wagner, T., and Pfeilsticker, K.: First profile measurements of

1296 tropospheric BrO, Geophys. Res. Lett., 27(18), 2921-2924, 2000.

1297 Galbally, I. E., Bentley, S.T., and Meyer, C.P.: Mid-latitude marine boundary-layer ozone

1298 destruction at visible sunrise observed at Cape Grim, Tasmania, Geophys. Res. Lett., 27,

1299 3841-3844, 2000.

1300 Gent, P. R., Yeager, S. G., Neale, R. B., Levis, S., and Bailey, D. A.: Improvements in a half

1301 degree atmosphere/land version of the CCSM, Climate Dynamics, doi:10.1007/s00382-

1302 009-0614-8, 2009.

1303 Granier, C., Guenther, A., Lamarque, J., Mieville, A., Müller, J., Olivier, J., Orlando, J.,

1304 Peters, 20 J., Petron, G., Tyndall, G., and Wallens, S.: POET, a database of surface 
emissions of ozone precursors, available at http://www.aero.jussieu.fr/ projet/ACCENT/POET.php, 2005.

Gregg, W. W.: Assimilation of SeaWIFS global ocean chlorophyll data into a threedimensional global ocean model, J. Mar. Sys., 69, 205-225, 2008.

Holmes, C. D., Jacob, D. J., Corbitt, E. S., Mao, J., Yang, X., Talbot, R., and Slemr, F.:

1310 Global atmospheric model for mercury including oxidation by bromine atoms, Atmos.

1311 Chem. Phys., 10, 12037-12057, doi:10.5194/acp-10-12037-2010, 2010.

1312 Kamra, A. K., Murugavel, P., and Pawar, S. D.: Measured size distributions of aerosols over the Indian Ocean during INDOEX, J. Geophys. Res., 108(D3), 8000, doi:10.1029/2002JD002200, 2003.

1315 Keene, W. C., Jacob, D. J., and Fan, S.-M.: Reactive chlorine: A potential sink for

1316 dimethylsulfide and hydrocarbons in the marine boundary layer, Atmos. Environ., 30(6), 1317 i-iii, 1996.

1318 Keene, W. C., Sander, R., Pszenny, A. A. P., Vogt, R., Crutzen, P.J., and Galloway, J.N.:

1319 Aerosol pH in the marine boundary layer: A review and model evaluation, J. Aerosol Sci, 29, 339-356, 1998.

1321 Keene, W. C., Stutz, J., Pszenny, A. A. P., Maben, J. R., Fischer, E., Smith, A. M., von

1322 Glasow, R., Pechtl, S., Sive, B. C., and Varner, R. K.: Inorganic chlorine and bromine in 1323 coastal New England air during summer, J. Geophys. Res., 112 (D10), D10S12, 2007.

1324 Keene, W. C., Long, M. S., Pszenny, A. A. P., Sander, R., Maben, J. R., Wall, A. J.,

1325 O'Halloran, T. L., Kerkweg, A., Fischer, E. V., and Schrems, O.: Latitudinal variation in

1326 the multiphase chemical processing of inorganic halogens and related species over the

1327 eastern North and South Atlantic Oceans, Atmos. Chem. Phys., 9, 7361-7385,

1328 doi:10.5194/acp-9-7361-2009, 2009.

1329 Kercher, J. P., Riedel, T. P., and Thornton, J. A.: Chlorine activation by $\mathrm{N}_{2} \mathrm{O}_{5}$ : simultaneous, in situ detection of $\mathrm{ClNO}_{2}$ and $\mathrm{N}_{2} \mathrm{O}_{5}$ by chemical ionization mass spectrometry, Atmos. Meas. Tech., 2, 193-204, doi:10.5194/amt-2-193-2009, 2009.

1332 Kerkweg, A., Sander, R., Tost, H., Jöckel, P., and Lelieveld, J.: Technical Note: Simulation 1333 of detailed aerosol chemistry on the global scale using MECCA-AERO, Atmos. Chem. 1334 Phys., 7, 2973-2985, doi:10.5194/acp-7-2973-2007, 2007.

1335 Kerkweg, A., Jöckel, P., Pozzer, A., Tost, H., Sander, R., Schulz, M., Stier, P., Vignati, E., 1336 Wilson, J., and Lelieveld, J.: Consistent simulation of bromine chemistry from the marine 
boundary layer to the stratosphere, Part I: model description, sea salt aerosols and $\mathrm{pH}$, Atmos. Chem. Phys., 8, 5899-5917, 2008.

Kokkola, H., Hommel, R., Kazil, J., Niemeier, U., Partanen, A.-I., Feichter, J., and Timmreck, C.: Aerosol microphysics modules in the framework of the ECHAM5 climate model - intercomparison under stratospheric conditions, Geosci. Model Dev. Discuss., 2, 209-246, doi:10.5194/gmdd-2-209-2009, 2009.

Lamarque, J.-F., Bond, T. C., Eyring, V., Granier, C., Heil, A., Klimont, Z., Lee, D., Stehfest, E., Van Aardenne, J., Cooper, O. R., Kainuma, M., Mahowald, N., McConnell, J. R., Naik, V., Riahi, K., and van Vuuren, D. P.: Historical (1850-2000) gridded anthropogenic and biomass burning emissions of reactive gases and aerosols: methodology and application, Atmos. Chem. Phys., 10, 7017-7039, doi:10.5194/acp-107017-2010, 2010.

Lawler, M. J., Finley, B. D. Keene, W. C., Pszenny, A. A. P., Read, K. A., von Glasow, R., and Saltzman, E. S.: Pollution-enhanced reactive chlorine chemistry in the eastern tropical Atlantic boundary layer, Geophys. Res. Lett., 36, L08810, doi:10.1029/2008GL036666, 2009.

Leitte, A.M., Schlink, U., Herbarth, O., Wiedensohler, A., Pan, X., Hu, M., Richter, M., Wehner, B., Tuch, T., Wu, Z., Yang, M., Liu, L., Breitner, B., Cyrys, J., Peters, A., Wichmann, H., and Franck, U.: Size-Segregated Particle Number Concentrations and Respiratory Emergency Room Visits in Beijing, China, Environ. Health Perspect., 119(4), 508-513, 2011.

Liu, X., Easter, R. C., Ghan, S. J., Zaveri, R., Rasch, P., Shi, X., Lamarque, J.-F., Gettelman, A., Morrison, H., Vitt, F., Conley, A., Park, S., Neale, R., Hannay, C., Ekman, A. M. L., Hess, P., Mahowald, N., Collins, W., Iacono, M. J., Bretherton, C. S., Flanner, M. G., and Mitchell, D.: Toward a minimal representation of aerosols in climate models: description and evaluation in the Community Atmosphere Model CAM5, Geosci. Model Dev., 5, 709-739, doi:10.5194/gmd-5-709-2012, 2012.

Long, M. S., Keene, W. C., Easter, R., Sander, R., Kerkweg, A., Erickson, D., Liu, X., and Ghan, S.: Implementation of the chemistry module MECCA (v2.5) in the modal aerosol version of the Community Atmosphere Model component (v3.6.33) of the Community Earth System Model, Geosci. Model Dev. Discuss., 5, 1483-1501, doi:10.5194/gmdd-51483-2012, 2012. 
Mårtensson, E.M., E.D. Nilsson, G. deLeeuw, L.H. Cohen, Hansson, H.-C.: Laboratory simulations and parameterization of the primary marine aerosol production, J. Geophys. Res., 108 (D9), doi:10.1029/2002JD002263, 2003.

Mäkelä J. M., Koponen, I. K., Aalto, P., and Kulmala, M.: One-year data of submicron size modes of tropospheric background aerosol in southern Finland, J. Aerosol Sci., 31, 595$1375611,2000$.

McDow, S. R., Jang, M., Hong, Y., and Kamens R.M.: An approach to studying the effects of organic composition on atmospheric aerosol photochemistry, J. Geophys. Res., 101, 19,593-19,600, 1996.

McElroy, C. T., McLinden, C. A., and McConnell, J. C.: Evidence for bromine monoxide in the free troposphere during the Arctic polar sunrise, Nature, 397, 338-340, 1999.

Monahan, E.C. and O'muircheartaigh, I.G.: Whitecaps and the passive remote-sensing of the ocean surface, Int. J. Rem. Sens., 7 (5), 627-642, 1986.

Montzka, S. A., Butler, J. H., Hall, B. D., Mondeel, D. J., and Elkins, J. W.: A decline in tropospheric organic bromine, Geophys. Res. Lett., 30, 1826, doi:1810.1029/2003GL017745, 2003.

Nagao I., Matsumoto, K., and Tanaka, H.: Sunrise ozone destruction found in the sub-tropical marine boundary layer, Geophys. Res. Lett., 26, 3377-3380, 1999.

O'Dowd, C. D., and Smith, M. H.: Physico-chemical properties of aerosol over the North East Atlantic: Evidence for wind speed related sub-micron sea-salt aerosol production, J. Geophys. Res., 98, 1137-1149, 1993.

O’Dowd, C. D., Smith, M. H., Consterdine, I. E., and Lowe, J. A.: Marine aerosol, sea-salt, and the marine sulphur cycle: A short review, Atmos. Environ., 31, 73-80, 1997.

Osthoff, H. D., Roberts, J. M., Ravishankara, A. R., Williams, E. J., Lerner, B. M., Sommariva, R., Bates, T. M., Coffman, D., Quinn, P. K., Dibb, J. E., Stark, H., Burkholder, J. B., Talukdar, R. K., Meagher, J., Fehsenfeld, F. C., and Brown, S. S.: High levels of nitryl chloride in the polluted subtropical marine boundary layer, Nature Geosci., 1, 324-328, doi:10.1038/ngeo177, 2008.

Phillips, G. J., Tang, M. J., Thieser, J., Brickwedde, B., Schuster, G., Bohn, B., Lelieveld, J., and Crowley, J. N.: Significant concentrations of nitryl chloride observed in rural continental Europe associated with the influence of sea salt chloride and anthropogenic emissions, Geophys. Res. Lett., 39, L10811, doi:10.1029/2012GL051912, 2012. 
Pierce, J. R. and Adams, P. J.: Global evaluation of CCN formation by direct emission of sea salt and growth of ultrafine sea-salt, J. Geophys. Res., 111, D06203, doi:10.1029/2005JD006186, 2006.

Piot, M. and von Glasow, R.: The potential importance of frost flowers, recycling on snow, and open leads for ozone depletion events: Atmos. Chem. Phys., 8, 2437-2467,

1408 Platt, U., Allan, W., and Lowe, D.: Hemispheric average $\mathrm{Cl}$ atom concentration from

$140913 \mathrm{C} / 12 \mathrm{C}$ ratios in atmospheric methane, Atmos. Chem. Phys., 4, 2393-2399,

1410 doi:10.5194/acp-4-2393-2004, 2004.

1411 Pszenny, A. A. P., Moldanová, J., Keene, W. C., Sander, R., Maben, J. R., Martinez, M.,

1412 Crutzen, P. J., Perner, D., and Prinn, R. G.: Inorganic halogens and aerosol pH in the

1413 Hawaiian marine boundary layer, Atmos. Chem. Phys., 4, 147-168, 2004.

1414 Pszenny, A. A. P., Fischer, E.V., Russo, R.S., Sive, B.C., and Varner, R.K.: Estimates of Cl

1415 atom concentrations and hydrocarbon kinetic reactivity in surface air at Appledore Island,

1416 Maine (USA), during International Consortium for Atmospheric Research on Transport

1417 and Transformation/Chemistry of Halogens at the Isles of Shoals, J. Geophys. Res., 112,

1418 D10S13, doi:10.1029/2006JD007725, 2007.

1419 Read, K. A., Majajan, A.S., Carpenter, L.J., Evans, M.J., Faria, B.V.E., Heard, D.E.,

1420 Hopkins, J.R., Lee, J.D., Moller, S.J., Lewis, A.C., Mendes, L., McQuaid, J.B., Oetjen,

1421 H., Saiz-Lopez, A., Pilling, M.J., and Plane, J.M.C.: Extensive halogen mediated ozone

1422 destruction over the tropical Atlantic Ocean, Nature, 453, 1232-1235, 2008.

1423 Richter, A., F. Wittrock, Ladstätter-Weißenmayer, A., and Burrows, J.P.: GOME

1424 measurements of stratospheric and tropospheric BrO, Adv. Space Res., 29(11), 1667-

$14251672,2002$.

1426 Riley, J. P., Chester, R. and Duce, R. A.: Chemical oceanography. Vol. 10. SEAREX : the

1427 Sea/Air Exchange Program / edited by J.P Riley and R. Chester Academic, 1989.Roscoe,

1428 H. K., Brough, N., Jones, A. E., Wittrock, F., Richter, A., Van Roozendael, M., and

1429 Hendrick, F.: Resolution of an important discrepancy between remote and in-situ

1430 measurements of tropospheric BrO during Antarctic enhancements, Atmos. Meas. Tech.

1431 Discuss., 5, 5419-5448, doi:10.5194/amtd-5-5419-2012, 2012.

1432 Roscoe, H. K., Brough, N., Jones, A. E., Wittrock, F., Richter, A., Van Roozendael, M., and

1433 Hendrick, F.: Resolution of an important discrepancy between remote and in-situ 
measurements of tropospheric $\mathrm{BrO}$ during Antarctic enhancements, Atmos. Meas. Tech. Discuss., 5, 5419-5448, doi:10.5194/amtd-5-5419-2012, 2012.

Rudolph, J., Koppmann, R., Plass-Duelmer, C.: The budgets of ethane and tetrachloroethene: Is there evidence for an impact of reactions with chlorine atoms in the troposphere?, Atmos. Environ., 3010, 1887-1894, 1996.

Ruuskanen, J., Tuch, T., Brink, H., Peters, A., Khlystov, A., Mirme, A., Kos, G.P.A., Brunekreef, B., Wichmann, H.E., Buzorius, G., Vallius, M., Kreyling, W.G., and Pekkanen, J.: Concentrations of ultrafine, fine and PM2.5 particles in three European cities, Atmos. Env., 35(21), 3729-3738, doi:10.1016/S1352-2310(00)00373-3, 2011.

Saiz-Lopez, A., Plane, J. M. C., and Shillito, J.A., Bromine oxide in the mid-latitude marine boundary layer, Geophys. Res. Lett., 31(3), doi:10.1029/2004GL03111, 2004.

Saiz-Lopez, A., Lamarque, J.-F., Kinnison, D. E., Tilmes, S., Ordóñez, C., Orlando, J. J., Conley, A. J., Plane, J. M. C., Mahajan, A. S., Sousa Santos, G., Atlas, E. L., Blake, D. R., Sander, S. P., Schauffler, S., Thompson, A. M., and Brasseur, G.:

Sander, R.: Modeling atmospheric chemistry: Interactions between gas-phase species and

Sander, R., Rudich, Y., von Glasow, R., and Crutzen, P. J.: The role of $\mathrm{BrNO}_{3}$ in marine tropospheric chemistry: A model study, Geophys. Res. Lett., 26, 2858-2860, 1999.

1462 Sander, R., Keene, W. C., Pszenny, A. A. P., Arimoto, R., Ayers, G. P., Baboukas, V., 1463 Chainey, J. M., Crutzen, P. J., Duce, R. A., Hönninger, G., Huebert, B. J., Maenhaut, W., 1464 Mihalopoulos, N., Turekian, V.C., and van Dingenan, R.: Inorganic bromine in the 1465 marine boundary layer: A critical review, Atmos. Chem. Phys, 3, 1301-1336, 2003. 
Sander, R., Kerkweg, A., Jöckel, P., and Lelieveld, J.: Technical note: The new comprehensive atmospheric chemistry module MECCA, Atmos. Chem. Phys., 5, 445-450, doi:10.5194/acp-5-445-2005, 2005.

1469 Savoie, D. L., Arimoto, R., Keene, W. C., Prospero, J. M., Duce, R. A., and Galloway, J. N.:

1470 Marine biogenic and anthropogenic contributions to non-sea-salt sulfate in the marine boundary layer over the North Atlantic Ocean, J Geophys. Res., 107(D18), 4356, doi:10.1029/2001JD000970, 2002.

Schwartz, S. E.: Mass-transport considerations pertinent to aqueous phase reactions of gases in liquid-water clouds, in Chemistry of Multiphase Atmospheric Systems, NATO ASI Series, Vol. G6 , edited by W. Jaeschke, pp. 415-471, Springer Verlag, Berlin, 1986. Simon, H., Kimura, Y., McGaughey, G., Allen, D.T., Brown, S.S., Osthoff, H.D., Roberts, J.M., Byun, R., and Lee, D.: Modeling the impact of $\mathrm{ClNO} 2$ on ozone formation in the Houston area, J. Geophys. Res., 114, D00F03, doi:10.1029/2008JD010732, 2009. Simpson, W. R., von Glasow, R., Riedel, K., Anderson, P., Ariya, P., Bottenheim, J., Jacobi, H.-W., Kaleschke, L., Neff, B., Plane, J., Platt, U., Richter, A., Roscoe, H., Sander, R., Shepson, P., Sodeau, J., Steffen, A., Wagner, T., and Wolff, E.: Halogens and their role in polar boundary-layer ozone depletion, Atmos. Chem. Phys., 7, 4375-4418, doi:10.5194/acp-7-4375-2007, 2007.

Singh, H.B., Gregory, G.L., Anderson, B., Browell, E., Sachse, G.W., Davis, D.D., Crawford, J., Bradshaw, J.D., Talbot, R., Blake, D.R., Thornton, D., Newell, R., Merrill, $\mathrm{J}$ : Low ozone in the marine boundary layer of the tropical Pacific Ocean: Photochemical loss, chlorine atoms, and entrainment, J. Geophys. Res., 101, 1907-1917, 1996.

Spracklen, D. V., Pringle, K. J., Carslaw, K. S., Chipperfield, M. P., and Mann, G. W.: A global off-line model of size-resolved aerosol microphysics: I. Model development and prediction of aerosol properties, Atmos. Chem. Phys., 5, 2227-2252, doi:10.5194/acp-52227-2005, 2005.

Stanier, C.O., Khlystov, A.Y., Pandis, S.N.: Ambient aerosol size distributions and number concentrations measured during the Pittsburgh Air Quality Study (PAQS). Atmos. Env., 38(20), 3275-3284, 2004. C., Orlando, J. J., Silva, P. J., Jimenez, J. L., Canagaratna, M. R., Neece, J. D., Mullins, 
C. B., and Allen, D. T.: Direct evidence for chlorine-enhanced urban ozone formation in Houston, Texas, Atmos. Environ., 37, 1393-1400, 2003.

1500 Textor, C., Schulz, M., Guibert, S., Kinne, S., Balkanski, Y., Bauer, S., Berntsen, T., Berglen, 1501 T., Boucher, O., Chin, M., Dentener, F., Diehl, T., Easter, R., Feichter, H., Fillmore, D., Ghan, S., Ginoux, P., Gong, S., Grini, A., Hendricks, J., Horowitz, L., Huang, P., Isaksen, I., Iversen, I., Kloster, S., Koch, D., Kirkevåg, A., Kristjansson, J. E., Krol, M., Lauer, A., Lamarque, J. F., Liu, X., Montanaro, V., Myhre, G., Penner, J., Pitari, G., Reddy, S., Seland, Ø., Stier, P., Takemura, T., and Tie, X.: Analysis and quantification of the diversities of aerosol life cycles within AeroCom, Atmos. Chem. Phys., 6, 1777-1813, 2006.

Thornton, J.A., Kercher, J.P., Riedel, T.P., Wagner, N.L., Cozic, J., Holloway, J.S., Dubé, W.P., Wolfe, G.M., Quinn, P.K., Middlebrook, A.M., Alexander, B., and Brown, S.S.: A large atomic chlorine source inferred from mid-continental reactive nitrogen chemistry, Nature, 464, doi:10.1038/nature08905, 2010.

Toumi, R.: BrO as a sink for dimethylsulfide in the marine atmosphere, Geophys. Res., Lett., 21, 117-120, 1994.

Vignati E, de Leeuw, G., Berkowicz, R.: Modeling coastal aerosol transport and effects of surf-produced aerosols on processes in the marine atmospheric boundary layer $\mathrm{J}$. Geophys. Res. 106, 20,225-20,238, 2001.

Vogt, R., Crutzen, P. J., and Sander, R.: A mechanism for halogen release from sea-salt aerosol in the remote marine boundary layer, Nature, 383, 327-330, 1996.

von Glasow R., Sander, R., Bott, A., and Crutzen, P. J.: Modeling halogen chemistry in the marine boundary layer. 2. Interactions with sulfur and cloud-covered MBL, J. Geophys. Res., 107, 4323, doi:10.1029/2001JD000943, 2002.

von Glasow, R. and Crutzen, P. J.: Model study of multiphase DMS oxidation with a focus on halogens. Atmos. Chem. Phys., 4, 589 - 608, 2004.

Wingenter, O.W., Kubo, M.K., Blake, N.J., Smith, Jr., T.W., Blake, D.R., and Rowland, F.S.: Hydrocarbon and halocarbon measurements as photochemical and dynamical indicators of atmospheric hydroxyl, atomic chlorine, and vertical mixing obtained during Lagrangian flights, J. Geophys. Res., 101, 4331-4340, 1996.

Wingenter, O.W., Blake, D.R., Blake, N.J., Sive, B.C., Atlas, E., Flocke, F., and Rowland, F.S.: Tropospheric hydroxyl and atomic chlorine concentrations, and mixing time scales 
1530 determined from hydrocarbon and halocarbon measurements made over the Southern 1531 Ocean, J. Geophys. Res., 104, 21,819-21,828, 1999.

1532 Yang, X., Cox, R. A., Warwick, N. J., Pyle, J. A., Carver, G. D., O’Connor, F. M., and

1533 Savage, N. H.: Tropospheric bromine chemistry and its impacts on ozone: A model

1534 study, J. Geophys. Res., 110, D23311, doi:10.1029/2005JD006244, 2005.

1535 Zhou X., Davis, A. J., Kieber, D. J., Keene, W. C., Maben, J. R., Maring, H., Dahl, E. E., 1536 Izaguirre, M. A., Sander, R., and Smoydzyn, L.: Photochemical production of hydroxyl

1537 radical and hydroperoxides in water extracts of nascent marine aerosols produced by

1538 bursting bubbles from Sargasso seawater, Geophys. Res. Lett., 35, L20803,

1539 doi:10.1029/2008GL035418, 2008. 
1540

1541

1542

1543

1544
Table 1. Global annual mean $\mathrm{Na}^{+}$burden, production flux, lifetime, dry and wet deposition fluxes, and global median (and range) aerosol number concentration compared with published results based on other marine aerosol source functions. Uncertainties correspond to year-over-year standard deviation for the 10-year annual mean.

\begin{tabular}{lcccccc} 
Study & $\begin{array}{c}\mathrm{Na}^{+} \text {Burden } \\
(\mathrm{Tg})\end{array}$ & $\begin{array}{c}\mathrm{Na}^{+} \text {Source } \\
\left(10^{3} \mathrm{Tg}^{-1}\right)\end{array}$ & $\begin{array}{c}\mathrm{Na}^{+} \text {Lifetime } \\
(\mathrm{d})\end{array}$ & $\begin{array}{c}\mathrm{Na}^{+} \text {Dry Dep. } \\
\left(10^{3} \mathrm{Tg} \mathrm{y}^{-1}\right)\end{array}$ & $\begin{array}{c}\mathrm{Na}^{+} \text {Wet Dep. } \\
\left(10^{3} \mathrm{Tg} \mathrm{y}^{-1}\right)\end{array}$ & Number Conc. $\left(\mathrm{cm}^{-3}\right)$ \\
\hline Hal (this work) & $2.5 \pm 0.03$ & $1.1 \pm 0.02$ & $0.86 \pm 0.01$ & $0.49 \pm 0.01$ & $0.56 \pm 0.01$ & $266\left(4.0 \times 10^{0}-4.4 \times 10^{4}\right)$ \\
Clarke et al. (2006) & 4.0 & 2.2 & 0.66 & 1.5 & 0.68 & \\
O'dowd et al. (1997) & 5.2 & 4.1 & 0.47 & 2.9 & 1.2 & 0.11 \\
Mårtensson et al. (2003) & 0.55 & 1.7 & 1.2 & 0.061 & 0.19 & 0.90 \\
Monahan et al. (1986) & 1.2 & 0.55 & 0.79 & 0.34 & \\
Kerkweg et al. (2008) & 2.4 & 1.7 & 0.5 & 0.76 & \\
Textor et al. (2006) & 2.4 & 1.6 & 0.5 & & \\
\hline
\end{tabular}


1545 Table 2. Median (and range) for total volatile $\mathrm{Br}\left(\mathrm{Br}_{\mathrm{t}} ; \mathrm{pmol} \mathrm{mol}{ }^{-1}\right)$ measured at Hawaii 1546 (Pszenny et al., 2004) and along a transect through the eastern North and South Atlantic 1547 Oceans (Keene et al., 2009) and statistics simulated for the surface layer within the 1548 corresponding grid cells. Reported median and ranges for simulated $\mathrm{Br}_{\mathrm{t}}$ along the transect 1549 are based on a box bounded by the North-South/East-West limits of the transect segment, 1550 as reported in Keene et al. (2009).

\begin{tabular}{lcc} 
Location and Time & Measured & Simulated \\
\hline Hawaii $\left(21^{\circ} \mathrm{N}, 158^{\circ} \mathrm{W}\right.$; Sep. 1999) & $3.7(<2-9)$ & $22.7(19.6-23.4)$ \\
NE Atlantic $\left(43-51^{\circ} \mathrm{N}, 2^{\circ} \mathrm{E}-10^{\circ} \mathrm{W}\right.$; Oct. 2003) & $7.2(3.1-12.3)$ & $17.5(2.3-63.9)$ \\
NE Atlantic $\left(10-33^{\circ} \mathrm{N}, 14-20^{\circ} \mathrm{W}\right.$; Oct.-Nov. 2003) & $18.8(8.2-30.1)$ & $14.5(7.2-29.5)$ \\
E Atlantic $\left(1-10^{\circ} \mathrm{N}, 13-20^{\circ} \mathrm{W}\right.$; Nov. 2003) & $2.4(<0.1-3.1)$ & $12.7(8.5-22.2)$ \\
SE Atlantic $\left(1 \mathrm{~N}-18 \mathrm{~S}, 4^{\circ} \mathrm{E}-13^{\circ} \mathrm{W}\right.$; Nov. 2003) & $6.2(4.4-10.1)$ & $17.5(0.1-44.4)$ \\
\hline
\end{tabular}


Table 3. Measured and simulated $\mathrm{BrO}$ mixing ratios $\left(\mathrm{pmol} \mathrm{mol}^{-1}\right) \pm$ standard deviations (when available) for sites reported by Sander et al. (2003; Table 4) and Read et al. (2008). Simulated results are based on 10-year temporal means for the surface layer during the sampling month and within the grid-box corresponding to the measurements.

\begin{tabular}{|c|c|c|c|c|}
\hline Location and Time & Measured & Simulated & Day/Night & $\begin{array}{c}\text { Est. Daytime } \\
\text { Mean }\end{array}$ \\
\hline Hawaii $\left(20^{\circ} \mathrm{N}, 155^{\circ} \mathrm{W}\right.$; Sep. 1999) & $<2$ & $2.2 \pm 0.20$ & 1.96 & $4.2 \pm 0.39$ \\
\hline Finokalia, Crete $\left(35^{\circ} \mathrm{N}, 26^{\circ} \mathrm{E}\right.$; Jul - Aug 2000) & $<0.7-1.5$ & $0.072 \pm 0.040$ & 1.68 & $0.12 \pm 0.067$ \\
\hline Made Head, Ireland $\left(53^{\circ} \mathrm{N}, 10^{\circ} \mathrm{W}\right.$; Apr - May 1997) & $1.1-2.5$ & $1.1 \pm 0.41$ & 1.60 & $1.7 \pm 0.66$ \\
\hline Made Head, Ireland $\left(53^{\circ} \mathrm{N}, 10^{\circ} \mathrm{W}\right.$; Sep - Oct 1998$)$ & $<1$ & $0.96 \pm 0.49$ & 2.04 & $2.0 \pm 1.0$ \\
\hline Tenerife, Canary Islands $\left(29^{\circ} \mathrm{N}, 17^{\circ} \mathrm{W}\right.$; Jun - Jul 1997) & 3 & $3.0 \pm 0.53$ & 1.71 & $5.2 \pm 0.9$ \\
\hline Weybourne, Great Britain $\left(53^{\circ} \mathrm{N}, 1^{\circ} \mathrm{E}\right.$; Oct 1996$)$ & $<2$ & $0.018 \pm 0.006$ & 2.29 & $0.040 \pm 0.013$ \\
\hline São Vicente, Cape Verde $\left(17^{\circ} \mathrm{N}, 25^{\circ} \mathrm{W}\right.$; Oct 2006 - Oct 2007$)$ & $2.5 \pm 1.1^{\mathrm{a}}$ & $2.9 \pm 0.93$ & 2.00 & $5.7 \pm 2.4$ \\
\hline
\end{tabular}


Table 4. Percentage contribution of different production pathways for atomic Br versus sum of all pathways based on ANN climatological means for different regions of the atmosphere.

\begin{tabular}{|c|c|c|c|c|c|c|c|}
\hline & PBL & $\mathrm{FT}$ & Trop. & $\mathrm{NH} \mathrm{CBL}$ & SH CBL & $\mathrm{NH} \mathrm{MBL}$ & SH MBL \\
\hline $\mathrm{BrO}+\mathrm{NO} \rightarrow \mathrm{Br}+\mathrm{NO}_{2}$ & $22 \%$ & $30 \%$ & $26 \%$ & $61 \%$ & $54 \%$ & $27 \%$ & $12 \%$ \\
\hline $\mathrm{HOBr}+\mathrm{hv} \rightarrow \mathrm{Br}+\mathrm{OH}$ & $12 \%$ & $27 \%$ & $19 \%$ & $5.6 \%$ & $7 \%$ & $9 \%$ & $12 \%$ \\
\hline $\mathrm{BrCl}+\mathrm{hv} \rightarrow \mathrm{Br}+\mathrm{Cl}$ & $18 \%$ & $8.5 \%$ & $14 \%$ & $9.9 \%$ & $9.2 \%$ & $23 \%$ & $15 \%$ \\
\hline $\mathrm{Br}_{2}+\mathrm{hv} \rightarrow \mathrm{Br}+\mathrm{Br}$ & $18 \%$ & $11 \%$ & $15 \%$ & $18 \%$ & $21 \%$ & $17 \%$ & $21 \%$ \\
\hline $\mathrm{BrO}+\mathrm{BrO} \rightarrow 2 \mathrm{Br}+\mathrm{O}_{2}$ & $15 \%$ & $11 \%$ & $13 \%$ & $3.0 \%$ & $5.9 \%$ & $8.4 \%$ & $23 \%$ \\
\hline $\mathrm{BrO}+\mathrm{ClO} \rightarrow \mathrm{Br}+\mathrm{OClO}$ & $5.0 \%$ & $5.8 \%$ & $5.3 \%$ & $1.0 \%$ & $0.4 \%$ & $5.4 \%$ & $3.3 \%$ \\
\hline $\mathrm{BrO}+\mathrm{ClO} \rightarrow \mathrm{Br}+\mathrm{Cl}+\mathrm{O}_{2}$ & $4.3 \%$ & $4.9 \%$ & $4.4 \%$ & $0.8 \%$ & $0.4 \%$ & $4.8 \%$ & $2.9 \%$ \\
\hline $\mathrm{BrO}+\mathrm{DMS} \rightarrow \mathrm{DMSO}+\mathrm{Br}$ & $2.9 \%$ & $0.3 \%$ & $1.8 \%$ & $0.1 \%$ & $0.5 \%$ & $3.2 \%$ & $8.0 \%$ \\
\hline $\mathrm{BrO}+\mathrm{CH}_{3} \mathrm{O}_{2} \rightarrow \mathrm{Br}+\mathrm{HCHO}+\mathrm{HO}_{2}$ & $2.0 \%$ & $1.0 \%$ & $1.6 \%$ & $0.4 \%$ & $0.4 \%$ & $2.1 \%$ & $2.1 \%$ \\
\hline $\mathrm{BrNO}_{2}+\mathrm{hv} \rightarrow \mathrm{Br}+\mathrm{NO}_{2}$ & $0.0 \%$ & $0.0 \%$ & $0.0 \%$ & $0.4 \%$ & $0.3 \%$ & $0.0 \%$ & $0.0 \%$ \\
\hline
\end{tabular}


Table 5. Relative contributions of different pathways to total direct $\mathrm{O}_{3}$ destruction in $\mathrm{Hal}$ and in $\mathrm{NoHal}$ simulations and the corresponding total $\mathrm{O}_{3}$ destruction via all pathways in $\mathrm{Hal}$ relative to $\mathrm{NoHal}$ simulations expressed as percentages; based on ANN means for different regions of the atmosphere.

\begin{tabular}{ccccccc} 
& PBL & FT & NH CBL & SH CBL & NH MBL & SH MBL \\
\hline$H a l$ & & & & & & \\
$\mathrm{R}_{\mathrm{O} 3+\mathrm{h} v} / \mathrm{R}_{\text {Hal Total }}$ & $60 \%$ & $41 \%$ & $30 \%$ & $34 \%$ & $66 \%$ & $74 \%$ \\
$\mathrm{R}_{\mathrm{O} 3+\mathrm{NO}} / \mathrm{R}_{\mathrm{Hal} \text { Total }}$ & $32 \%$ & $39 \%$ & $68 \%$ & $60 \%$ & $28 \%$ & $8.1 \%$ \\
$\mathrm{R}_{\mathrm{O} 3+\mathrm{Br}} / \mathrm{R}_{\mathrm{Hal} \text { Total }}$ & $6.2 \%$ & $15 \%$ & $0.8 \%$ & $1.3 \%$ & $4.4 \%$ & $16 \%$ \\
$\mathrm{R}_{\mathrm{O} 3+\mathrm{Cl}} / \mathrm{R}_{\text {Hal Total }}$ & $0.6 \%$ & $0.9 \%$ & $0.2 \%$ & $0.1 \%$ & $0.7 \%$ & $0.7 \%$ \\
NoHal & & & & & & \\
$\mathrm{R}_{\mathrm{O} 3+\mathrm{h} v} / \mathrm{R}_{\text {NoHal Total }}$ & $76 \%$ & $56 \%$ & $71 \%$ & $38 \%$ & $47 \%$ & $78 \%$ \\
$\mathrm{R}_{\mathrm{O} 3+\mathrm{NO}} / \mathrm{R}_{\text {NoHal Total }}$ & $23 \%$ & $40 \%$ & $27 \%$ & $60 \%$ & $49 \%$ & $21 \%$ \\
$\mathrm{R}_{\mathrm{Hal} \mathrm{Total}} / \mathrm{R}_{\text {NoHal Total }}$ & $58 \%$ & $76 \%$ & $81 \%$ & $74 \%$ & $57 \%$ & $38 \%$ \\
\hline
\end{tabular}

${ }^{1}$ Relatively lower rates of direct $\mathrm{O}_{3}$ destruction via all pathways in $\mathrm{Hal}$ simulations are driven in part by relatively lower steady-state $\mathrm{O}_{3}$ mixing ratios (see Fig. 7). 
Table 6. WOUDC stations (and corresponding periods of record) at which the vertical profiles in $\mathrm{O}_{3}$ evaluated herein were measured.

\begin{tabular}{ccccccc}
$\begin{array}{c}\text { Station } \\
\text { Code }\end{array}$ & Station Name & LAT & LON & Altitude $(\mathrm{m})$ & Start Date & Stop Date \\
\hline 21 & Edmonton & 53.6 & -114 & 766 & Jan. 1980 & Dec. 1993 \\
24 & Resolute & 74.7 & -95.0 & 40 & Jan. 1980 & Dec. 1993 \\
67 & Boulder & 40.0 & -105 & 1634 & Jan. 1985 & Dec. 1993 \\
432 & Tahiti & -18.0 & -149 & 2 & Jan. 1998 & Dec. 1999 \\
175 & Nairobi & -1.27 & 36.9 & 1795 & Jan. 1998 & Dec. 2001 \\
434 & San Cristobal & -0.92 & -89.6 & 8 & Mar. 1998 & Dec. 2001 \\
435 & Paramaribo & 5.81 & -55.2 & 25 & Oct. 1999 & Dec. 2001 \\
191 & Samoa & -14.3 & -170 & 82 & Apr. 1986 & Dec. 2002 \\
219 & Natal & -5.84 & -35.2 & 32 & Jan. 1998 & Dec. 2002 \\
265 & Pretoria & -25.6 & 28.2 & 1524 & Jul. 1990 & Dec. 2002 \\
436 & Reunion & -21.1 & 55.5 & 24 & Jan. 1998 & Dec. 2002 \\
448 & Malindi & -2.99 & 40.2 & -6 & Mar. 1999 & Dec. 2002 \\
437 & Java & -7.57 & 112 & 50 & Jan. 1998 & Nov. 2002 \\
438 & Fiji & -18.1 & 178 & 6 & Jan. 1998 & Nov. 2002 \\
\hline
\end{tabular}


Table 7. Global annual budgets for $\mathrm{SO}_{2}, \mathrm{H}_{2} \mathrm{SO}_{4}, \mathrm{nss}_{-} \mathrm{SO}_{4}{ }^{2-}$, and DMS, for $\mathrm{Hal}$, NoHal simulations, and a 5-year simulation using 3-mode modal-CAM (v3.6.33) with its standard chemical module. Ranges of results from previous studies are shown for comparison.

\begin{tabular}{|c|c|c|c|c|}
\hline & $\mathrm{Hal}$ & $\mathrm{NoHal}$ & CAM 3.6.33 & Previous Studies \\
\hline \multicolumn{5}{|c|}{$\mathrm{SO}_{2}$} \\
\hline Sources (Tg S/y) & 79.3 & 80.6 & 84.4 & $83.0-124.6^{b}$ \\
\hline Emission & 67.5 & 67.5 & 67.5 & $63.7-92.0^{\mathrm{a}}$ \\
\hline DMS Oxidation & 11.8 & 13.1 & 16.9 & $10.0-24.7^{\mathrm{a}}$ \\
\hline Sink (Tg S/y) & 80.5 & 82.8 & 87.0 & \\
\hline Dry Deposition & 20.3 & 21.4 & 22.5 & $16.0-55.0^{\mathrm{a}}$ \\
\hline Wet Deposition & 14.7 & 13.8 & 14.6 & $0.0-19.9^{a}$ \\
\hline Gas Oxidation & 6.2 & 6.4 & 11.9 & $6.1-16.8^{a}$ \\
\hline Aqueous Oxidation & 39.3 & 41.2 & 38.0 & $24.5-57.8^{\mathrm{a}}$ \\
\hline Burden (Tg S) & 0.57 & 0.57 & 0.31 & $0.20-0.61^{a}$ \\
\hline Lifetime (d) & 2.6 & 2.6 & 1.5 & $0.60-2.6^{\mathrm{a}}$ \\
\hline \multicolumn{5}{|c|}{$\mathrm{H}_{2} \mathrm{SO}_{4}$} \\
\hline $\mathrm{SO}_{2}+\mathrm{OH}$ & 6.2 & 6.4 & 11.9 & $6.1-22.0^{\mathrm{a}}$ \\
\hline Sink (Tg S/y) & 5.9 & 6.2 & 11.8 & \\
\hline Nucleation & 1.2 & 1.3 & 0.01 & $0.05-0.07^{b}$ \\
\hline Condensation & 4.6 & 4.8 & 10.9 & $13.0-15.2^{b}$ \\
\hline Cloud Scavenging & 0.1 & 0.1 & 0.9 & \\
\hline Burden (Tg S) & 0.0029 & 0.0032 & $1.2 \times 10^{-3}$ & $9.0 \times 10^{6}-.001^{a}$ \\
\hline Lifetime (h) & 4.1 & 4.4 & 0.086 & $0.12-0.17^{a}$ \\
\hline \multicolumn{5}{|c|}{ nss-SO ${ }_{4}^{2-}$} \\
\hline Sources (Tg S/y) & 46.9 & 49.1 & 50.6 & $59.7 \pm 13.2^{\mathrm{a}}$ \\
\hline Emission & 1.7 & 1.7 & 1.7 & \\
\hline Aqueous S(IV) Oxidation & 39.3 & 41.2 & 38.0 & \\
\hline Microphysics ${ }^{c}$ & 5.9 & 6.2 & 10.9 & \\
\hline Sink (Tg S/y) & 45.1 & 47.3 & 51.8 & \\
\hline Dry Deposition & 11.8 & 12.7 & 10.3 & \\
\hline Wet Deposition & 33.3 & 34.6 & 41.5 & \\
\hline Burden (Tg S) & 0.86 & 0.88 & 0.67 & $0.66 \pm 0.17^{\mathrm{a}}$ \\
\hline Lifetime (h) & 5.6 & 5.4 & 4.8 & $4.1 \pm 0.74^{\mathrm{a}}$ \\
\hline \multicolumn{5}{|c|}{ DMS } \\
\hline Emission (Tg S/y) & 18.3 & 18.3 & 18.3 & $10.7-23.7^{\mathrm{a}}$ \\
\hline Sinks: Gas Oxidation (Tg S/y) & 18.3 & 18.3 & 18.4 & \\
\hline Burden (Tg S) & 0.032 & 0.15 & 0.029 & $0.02-0.15^{\mathrm{a}}$ \\
\hline Lifetime (h) & 0.64 & 3.0 & 0.57 & $0.024-0.13^{a}$ \\
\hline
\end{tabular}

${ }^{a}$ From Liu et al. (2012) and references therein. ${ }^{b}$ From Spracklen et al. (2005) and references therein.

${ }^{\mathrm{c}}$ Combined source of nss- $\mathrm{SO}_{4}{ }^{2-}$ due to $\mathrm{H}_{2} \mathrm{SO}_{4}(\mathrm{~g})$ nucleation, condensation, and scavenging. 
Table 8. Relative contributions of different reaction pathways (R) to total DMS and S(IV) oxidation in $\mathrm{Hal}$ and in NoHal simulations and the corresponding total DMS and S(IV) oxidation via all pathways in Hal versus NoHal simulations expressed as percentages; based on ANN means, and spatial medians for different regions of the atmosphere. Subscripts $a q$ and $c l$ designate aerosol and cloudwater reactions, respectively.

\begin{tabular}{|c|c|c|c|c|c|c|c|}
\hline & PBL & FT & Troposphere & NH CBL & SH CBL & NH MBL & SH MBL \\
\hline \multicolumn{8}{|l|}{ DMS(Hal) } \\
\hline $\mathrm{R}_{\mathrm{DMS}+\mathrm{OH}} / \mathrm{R}_{\mathrm{DMS}-\text { Hal } \text {-Total }}$ & $6.6 \%$ & $27 \%$ & $8.3 \%$ & $9.3 \%$ & $18 \%$ & $12 \%$ & $4.0 \%$ \\
\hline $\mathrm{R}_{\mathrm{DMS}+\mathrm{NO} 3} / \mathrm{R}_{\mathrm{DMS}-\mathrm{Hal} \text {-Total }}$ & $11 \%$ & $14 \%$ & $11 \%$ & $69 \%$ & $53 \%$ & $24 \%$ & $3.8 \%$ \\
\hline $\mathrm{R}_{\mathrm{DMS}+\mathrm{Cl}} / \mathrm{R}_{\mathrm{DMS}-\text { Hal-Total }}$ & $14 \%$ & $8.4 \%$ & $14 \%$ & $9.3 \%$ & $5.0 \%$ & $20 \%$ & $9.1 \%$ \\
\hline $\mathrm{R}_{\mathrm{DMS}+\mathrm{BrO}} / \mathrm{R}_{\mathrm{DMS}-\text { Hal-Total }}$ & $68 \%$ & $50 \%$ & $67 \%$ & $12 \%$ & $24 \%$ & $44 \%$ & $82 \%$ \\
\hline \multicolumn{8}{|l|}{$D M S(\mathrm{NoHal})$} \\
\hline $\mathrm{R}_{\mathrm{DMS}+\mathrm{OH}} / \mathrm{R}_{\mathrm{DMS}-\text { NoHal-Total }}$ & $54 \%$ & $74 \%$ & $57 \%$ & $13 \%$ & $31 \%$ & $34 \%$ & $66 \%$ \\
\hline $\mathrm{R}_{\mathrm{DMS}+\mathrm{NO} 3} / \mathrm{R}_{\mathrm{DMS}-\mathrm{NoHal} \text {-Total }}$ & $46 \%$ & $26 \%$ & $43 \%$ & $87 \%$ & $69 \%$ & $66 \%$ & $34 \%$ \\
\hline $\mathrm{R}_{\text {DMS-Hal-Total }} / \mathrm{R}_{\text {DMS-NoHal-Total }}{ }^{1}$ & $140 \%$ & $52 \%$ & $122 \%$ & $73 \%$ & $43 \%$ & $118 \%$ & $227 \%$ \\
\hline
\end{tabular}

${ }^{1}$ Differences are driven in part by corresponding differences in steady state concentrations of DMS and S(IV) in Hal and NoHal simulation. 


\section{PBL $\quad$ FT $\quad$ Troposphere NHCBL SH CBL NH MBL SH MBL}

\begin{tabular}{|c|c|c|c|c|c|c|c|}
\hline \multirow{2}{*}{\multicolumn{8}{|c|}{$S(I V)(H a l)$}} \\
\hline & & & & & & & \\
\hline $\mathrm{R}_{\mathrm{SO} 2+\mathrm{OH}} / \mathrm{R}_{\mathrm{S}(\mathrm{IV}) \text { Total }}$ & $11 \%$ & $13 \%$ & $11 \%$ & $11 \%$ & $5.7 \%$ & $18 \%$ & $6.5 \%$ \\
\hline $\mathrm{R}_{\mathrm{S}(\mathrm{IV}) \mathrm{aq}}+\mathrm{H} 2 \mathrm{O} 2 / \mathrm{R}_{\mathrm{S}(\mathrm{IV})-\text { Hal-Total }}$ & $1.3 \%$ & $0.6 \%$ & $1.2 \%$ & $1.0 \%$ & $0.2 \%$ & $2.3 \%$ & $2.0 \%$ \\
\hline $\mathrm{R}_{\mathrm{S}(\mathrm{IV}) \mathrm{aq}+\mathrm{O} 3} / \mathrm{R}_{\mathrm{S}(\mathrm{IV})-\text { Hal } \text {-Total }}$ & $0.1 \%$ & $0.0 \%$ & $0.1 \%$ & $0.0 \%$ & $0.1 \%$ & $0.0 \%$ & $0.8 \%$ \\
\hline $\mathrm{R}_{\mathrm{S}(\mathrm{IV}) \mathrm{aq}}+\mathrm{HOCl} / \mathrm{R}_{\mathrm{S}(\mathrm{IV})-\text { Hal-Total }}$ & $0.9 \%$ & $0.2 \%$ & $0.8 \%$ & $0.1 \%$ & $0.0 \%$ & $2.0 \%$ & $4.9 \%$ \\
\hline $\mathrm{R}_{\mathrm{S}(\mathrm{IV}) \mathrm{aq}}+\mathrm{HOBr} / \mathrm{R}_{\mathrm{S}(\mathrm{IV}) \text {-Hal-Total }}$ & $0.2 \%$ & $0.1 \%$ & $0.2 \%$ & $0.0 \%$ & $0.0 \%$ & $0.0 \%$ & $2.0 \%$ \\
\hline $\mathrm{R}_{\mathrm{S}(\mathrm{IV}) \mathrm{cl}+\mathrm{H} 2 \mathrm{O} 2} / \mathrm{R}_{\mathrm{S}(\mathrm{IV})-\text { Hal-Total }}$ & $74 \%$ & $81 \%$ & $75 \%$ & $60 \%$ & $90 \%$ & $73 \%$ & $81 \%$ \\
\hline $\mathrm{R}_{\mathrm{S}(\mathrm{IV}) \mathrm{cl}+\mathrm{O} 3} / \mathrm{R}_{\mathrm{S}(\mathrm{IV})-\text { Hal-Total }}$ & $12 \%$ & $1.9 \%$ & $11 \%$ & $27 \%$ & $4.2 \%$ & $4.8 \%$ & $2.1 \%$ \\
\hline $\mathrm{R}_{\mathrm{S}(\mathrm{IV}) \mathrm{cl}+\mathrm{HOCl}} / \mathrm{R}_{\mathrm{S}(\mathrm{IV})-H a l-\text { Total }}$ & $0.2 \%$ & $1.3 \%$ & $0.4 \%$ & $0.1 \%$ & $0.0 \%$ & $0.0 \%$ & $0.2 \%$ \\
\hline $\mathrm{R}_{\mathrm{S}(\mathrm{IV}) \mathrm{cl}+\mathrm{HOBr}} / \mathrm{R}_{\mathrm{S}(\mathrm{IV})-\text { Hal-Total }}$ & $0.6 \%$ & $1.8 \%$ & $0.8 \%$ & $0.8 \%$ & $0.2 \%$ & $0.2 \%$ & $0.5 \%$ \\
\hline $\mathrm{R}_{\mathrm{S}(\mathrm{IV}) \mathrm{aq}} / \mathrm{R}_{\mathrm{S}(\mathrm{IV}) \mathrm{cl}}$ & $2.8 \%$ & $1.1 \%$ & $2.6 \%$ & $1.4 \%$ & $0.3 \%$ & $5.6 \%$ & $12 \%$ \\
\hline \multicolumn{8}{|l|}{$S(I V)(N o H a l)$} \\
\hline $\mathrm{R}_{\mathrm{SO} 2+\mathrm{OH}} / \mathrm{R}_{\mathrm{S}(\mathrm{IV})-\mathrm{NoHal} \text {-Total }}$ & $10 \%$ & $14 \%$ & $11 \%$ & $8.5 \%$ & $5.0 \%$ & $17 \%$ & $9.1 \%$ \\
\hline 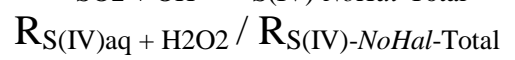 & $1.1 \%$ & $0.5 \%$ & $1.0 \%$ & $0.8 \%$ & $0.1 \%$ & $1.5 \%$ & $1.9 \%$ \\
\hline $\mathrm{R}_{\mathrm{S}(\mathrm{IV}) \mathrm{aq}+\mathrm{O} 3} / \mathrm{R}_{\mathrm{S}(\mathrm{IV})-\mathrm{NoHal} \text {-Total }}$ & $0.2 \%$ & $0.0 \%$ & $0.2 \%$ & $0.0 \%$ & $0.0 \%$ & $0.0 \%$ & $3.1 \%$ \\
\hline $\mathrm{R}_{\mathrm{S}(\mathrm{IV}) \mathrm{cl}+\mathrm{H}_{2} \mathrm{O} 2} / \mathrm{R}_{\mathrm{S}(\mathrm{IV})-\text { NoHal-Total }}$ & $76 \%$ & $81 \%$ & $76 \%$ & $59 \%$ & $90 \%$ & $74 \%$ & $83 \%$ \\
\hline $\mathrm{R}_{\mathrm{S}(\mathrm{IV}) \mathrm{cl}+\mathrm{O} 3} / \mathrm{R}_{\mathrm{S}(\mathrm{IV})-\mathrm{NoHal} \text {-Total }}$ & $13 \%$ & $5.1 \%$ & $12 \%$ & $31 \%$ & $5.3 \%$ & $7.5 \%$ & $2.8 \%$ \\
\hline $\mathrm{R}_{\mathrm{S}(\mathrm{IV}) \mathrm{aq}} / \mathrm{R}_{\mathrm{S}(\mathrm{IV}) \mathrm{cl}}$ & $1.5 \%$ & $0.6 \%$ & $1.4 \%$ & $0.9 \%$ & $0.1 \%$ & $1.9 \%$ & $5.9 \%$ \\
\hline $\mathrm{R}_{\mathrm{S}(\mathrm{IV})-\text { Hal-Total }} / \mathrm{R}_{\mathrm{S}(\mathrm{IV}) \text {-NoHal-Total }} 1$ & $88 \%$ & $88 \%$ & $89 \%$ & $88 \%$ & $87 \%$ & $86 \%$ & $89 \%$ \\
\hline
\end{tabular}

${ }^{1}$ Differences are driven in part by corresponding differences in steady state concentrations of DMS and S(IV) in Hal and NoHal simulation. 
Table 9: Mean particle number concentrations \pm standard deviations when available $\left(\mathrm{cm}^{-3}\right)$ measured at surface locations and the median and range for number concentrations simulated with $\mathrm{Hal}$ in the surface layer of the corresponding grid cells. Simulated values are summed across all three particle modes.

\begin{tabular}{lccccl} 
& \multicolumn{5}{c}{ Simulated (Hal) } \\
Location & Observed & Median & Max & Min & Source \\
\hline Alkmaar, Netherlands & $25800 \pm 11300$ & 2597 & 23508 & 815 & Ruuskanen et al. 2001 \\
Erfurt, Germany & $25900 \pm 12200$ & 2767 & 35180 & 759 & Ruuskanen et al. 2001 \\
Helsinki, Finland & $20300 \pm 8200$ & 2628 & 13134 & 610 & Ruuskanen et al. 2001 \\
Pittsburg, PA, USA & 16470 & 13037 & 48678 & 2592 & Stanier et al., 2004 \\
Beijing, PRC & $29000 \pm 10000$ & 11340 & 66393 & 1697 & Leitte et al., 2011 \\
Indian Ocean (North of ITCZ) & $856 \pm 232$ & 324 & 1393 & 151 & Kamra et al., 2003 \\
Indian Ocean (ITCZ) & $418 \pm 151$ & 232 & 1277 & 74 & Kamra et al., 2003 \\
Indian Ocean (South of ITCZ) & $334 \pm 20$ & 277 & 884 & 104 & Kamra et al., 2003 \\
Melpitz, Germany & 4830 & 2767 & 35180 & 759 & Birmili et al. 2001 (as reported by Spracklen et al., 2005) \\
Hyytiälä, Finland & $1813 \pm 1525$ & 1708 & 7846 & 415 & Mäkelä et al., 2000 \\
\hline
\end{tabular}


Table 10. Correlation coefficients (R), normalized mean square error (NMSE), and mean deviations of measured $\mathrm{SO}_{2}(\mathrm{~g})$ and $\mathrm{nss}-\mathrm{SO}_{4}{ }^{2-}$ versus mean simulated values in the surface layer of the corresponding grid cell with $\mathrm{Hal}$ and $\mathrm{NoHal}$, as plotted in Fig. 13.

Continental measurement are from the IMPROVE network; and marine measurements are from the Atmosphere-Ocean Chemistry Experiment (AEROCE, Savoie et al., 2002), U.S. Department of Energy as the Environmental Measurements Laboratory (DOEEML), and the Sea-Air Exchange Experiment (SEAREX, Riley et al., 1989).

\begin{tabular}{|c|c|c|c|c|}
\hline & & $\mathrm{R}$ & NMSE & Mean Deviation \\
\hline \multirow{3}{*}{ Hal } & $\mathrm{SO}_{2}(\mathrm{~g})$ & 0.53 & 2.9 & $2.7( \pm 8.8)$ \\
\hline & Continental nss- $\mathrm{SO}_{4}{ }^{2-}$ & 0.87 & 0.083 & $0.59( \pm 2.0)$ \\
\hline & Marine nss-SO ${ }_{4}^{2-}$ & 0.93 & 0.083 & $1.9( \pm 2.6)$ \\
\hline \multirow{3}{*}{ NoHal } & $\mathrm{SO}_{2}(\mathrm{~g})$ & 0.54 & 2.8 & $2.6( \pm 8.8)$ \\
\hline & Continental nss- $\mathrm{SO}_{4}{ }^{2-}$ & 0.82 & 0.095 & $0.55( \pm 2.2)$ \\
\hline & Marine nss- $\mathrm{SO}_{4}{ }^{2-}$ & 0.89 & 0.086 & $2.1( \pm 2.6)$ \\
\hline
\end{tabular}




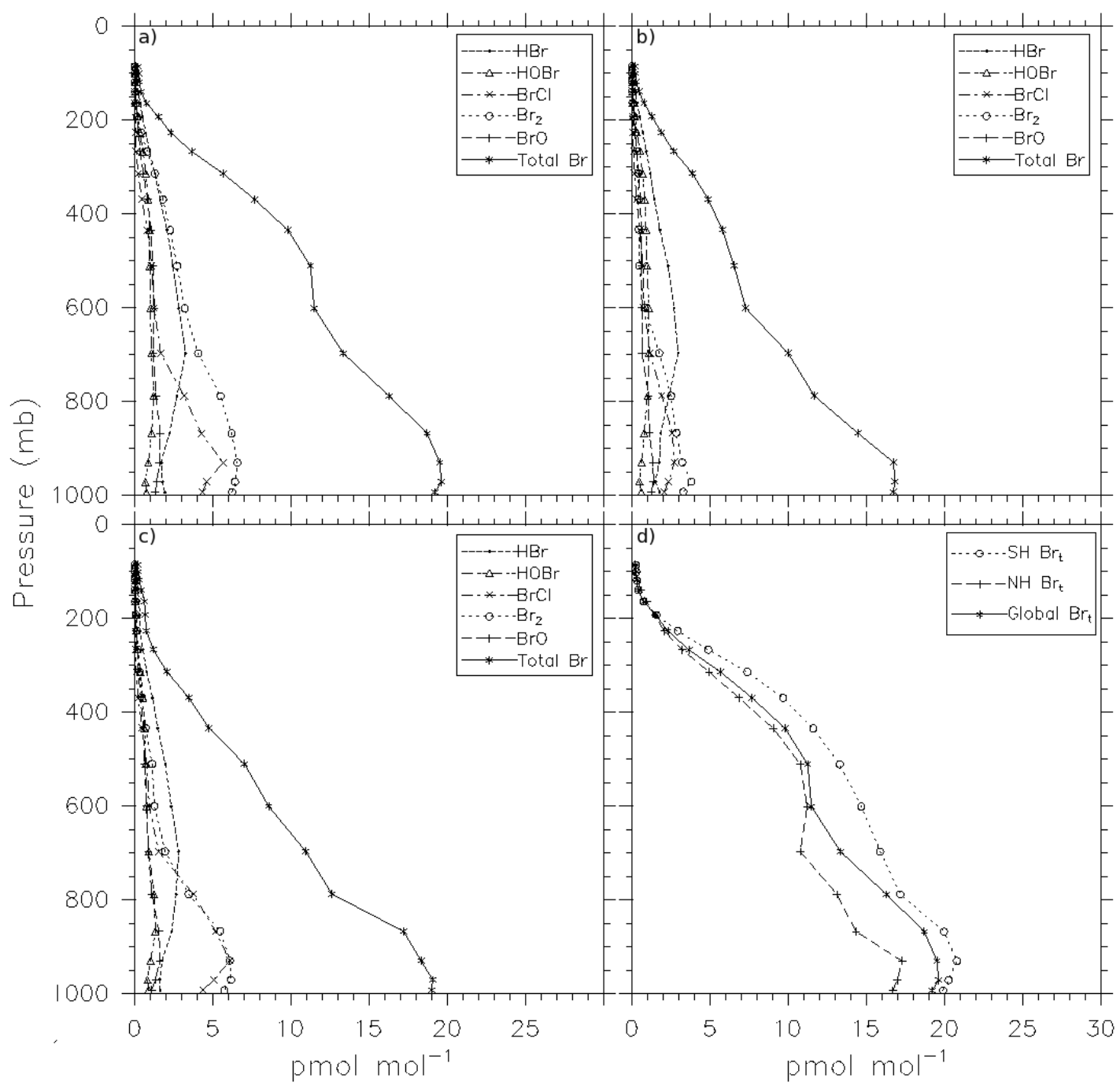

Figure 1. Spatial median vertical profiles of $\mathrm{Br}_{\mathrm{t}}$ and its component gases for (a) ANN, (b) JJA, and (c) DJF; (d) ANN $\mathrm{Br}_{\mathrm{t}}$ for $\mathrm{NH}, \mathrm{SH}$ and global regions. 


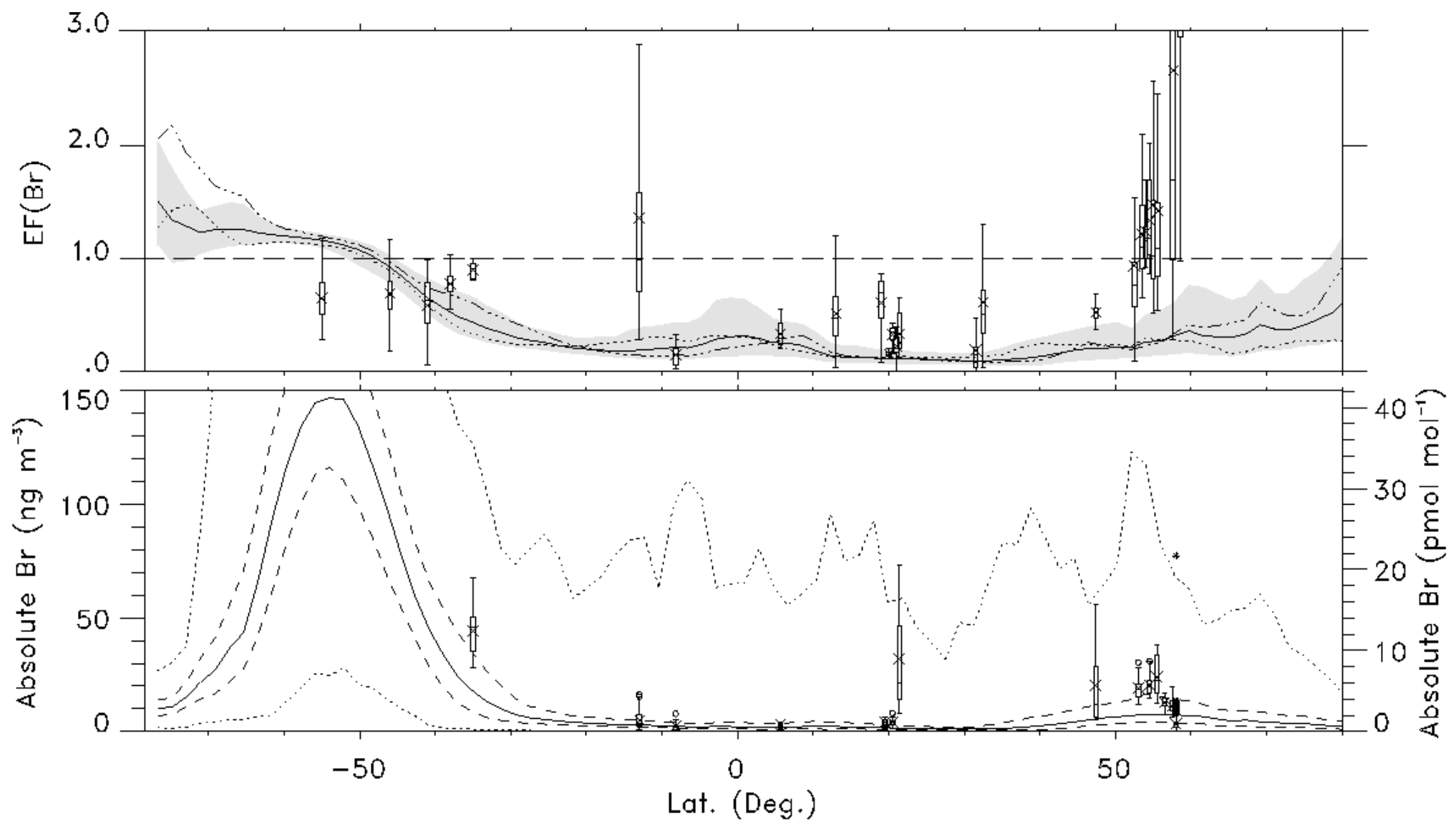

Figure 2. Simulated zonal (a) $\mathrm{EF}(\mathrm{Br})$ and (b) absolute $\mathrm{Br}^{-}$concentration and the corresponding measurement values reported by Sander et al. (2003) and Keene et al. (2009). See Appendix A for a listing of measurement sources. Box-and-whiskers indicate minimum, $25^{\text {th }}$ quartile, median, $75^{\text {th }}$ quartile and maximum values where maxima and minima are of data within 1.5 times the $25^{\text {th }}-75^{\text {th }}$ quartile range. Crosses indicate means. In (a), simulated media are indicated by the solid line, the shaded area depicts $25^{\text {th }}-75^{\text {th }}$ quartile range, the dash-dotted line depicts the JJA median, andthe dotted line depicts the DJF median. The horizontal dashed line indicates unity (i.e., no enrichment or depletion relative to conservative sea-salt species). In (b) simulated media are indicated by the solid line, $25^{\text {th }}$ and $75^{\text {th }}$ quartiles by the dashed lines, and maxima and minima by the dotted lines. 

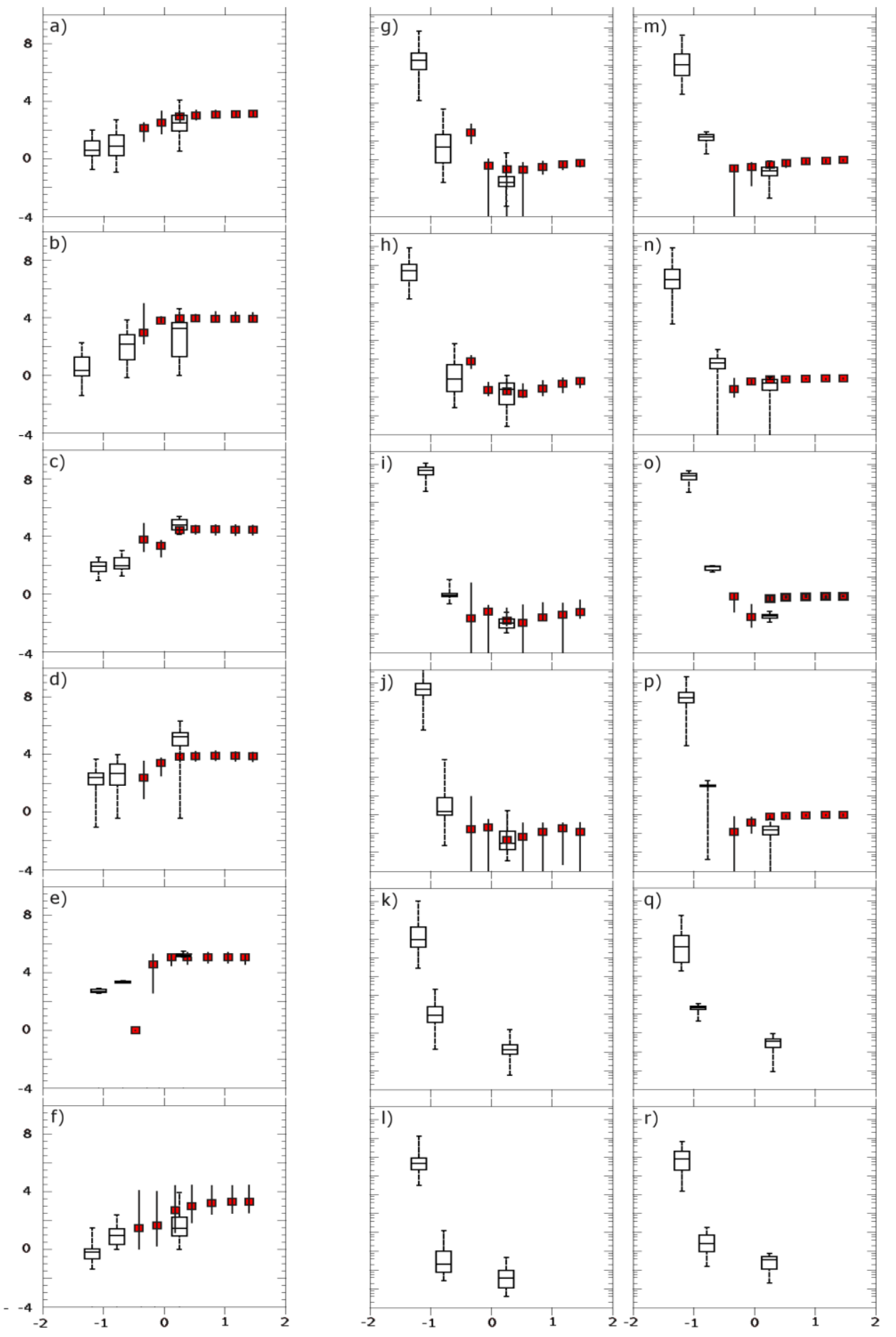

Figure 3. Size-resolved (a through $\mathrm{f}$ ) $\mathrm{pH}$ inferred from measurements (g through $\mathrm{j}$ ) and (where available) measured $\mathrm{EF}(\mathrm{Br})$ and $(\mathrm{k}$ through $\mathrm{n}) \mathrm{EF}(\mathrm{Cl})$ (in red) and the corresponding values simulated with $\mathrm{Hal}$ (in black). Box-and-whiskers depict maximum, $75^{\text {th }}$ quartile, median, $25^{\text {th }}$ quartile, and minimum values. The top four rows correspond to the regions in the eastern North and South Atlantic Oceans reported by Keene et al. (2009): Row 1 is EURO, 2 is NAFR, 3 is ITCZ, and 4 is SATL. Row 5 corresponds to Hawaii (Pszenny et al., 2004), and Row 6 corresponds to the New England Air Quality Study (NEAQS) along the U.S. East Coast (Keene et al., 2004). 

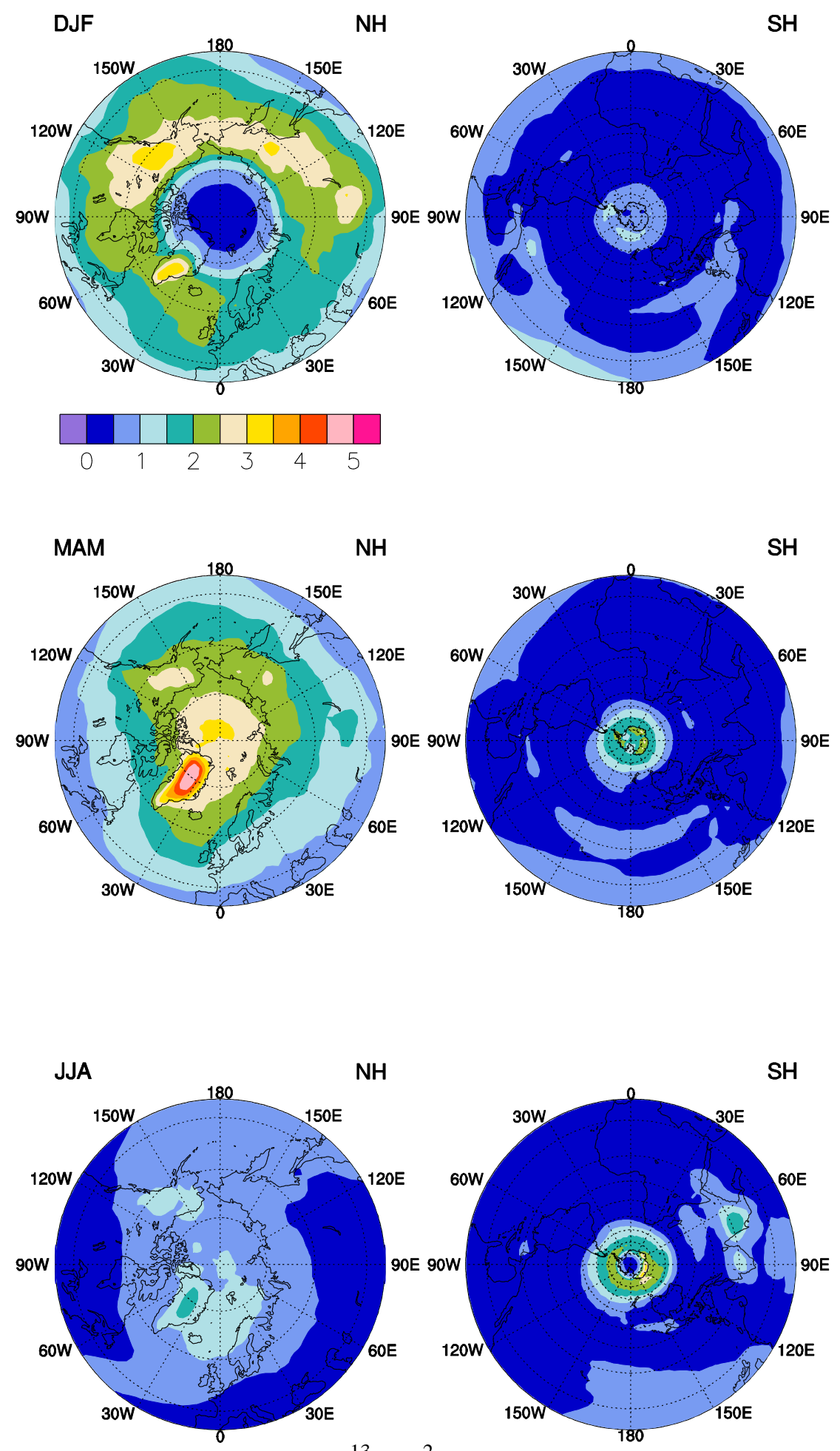

Figure 4. Vertically integrated $\mathrm{BrO}\left(10^{13} \mathrm{~cm}^{-2}\right)$ for the northern and southern hemispheres (NH, SH), averaged over winter (DJF), spring (MAM; March-April-May), and summer (JJA). 

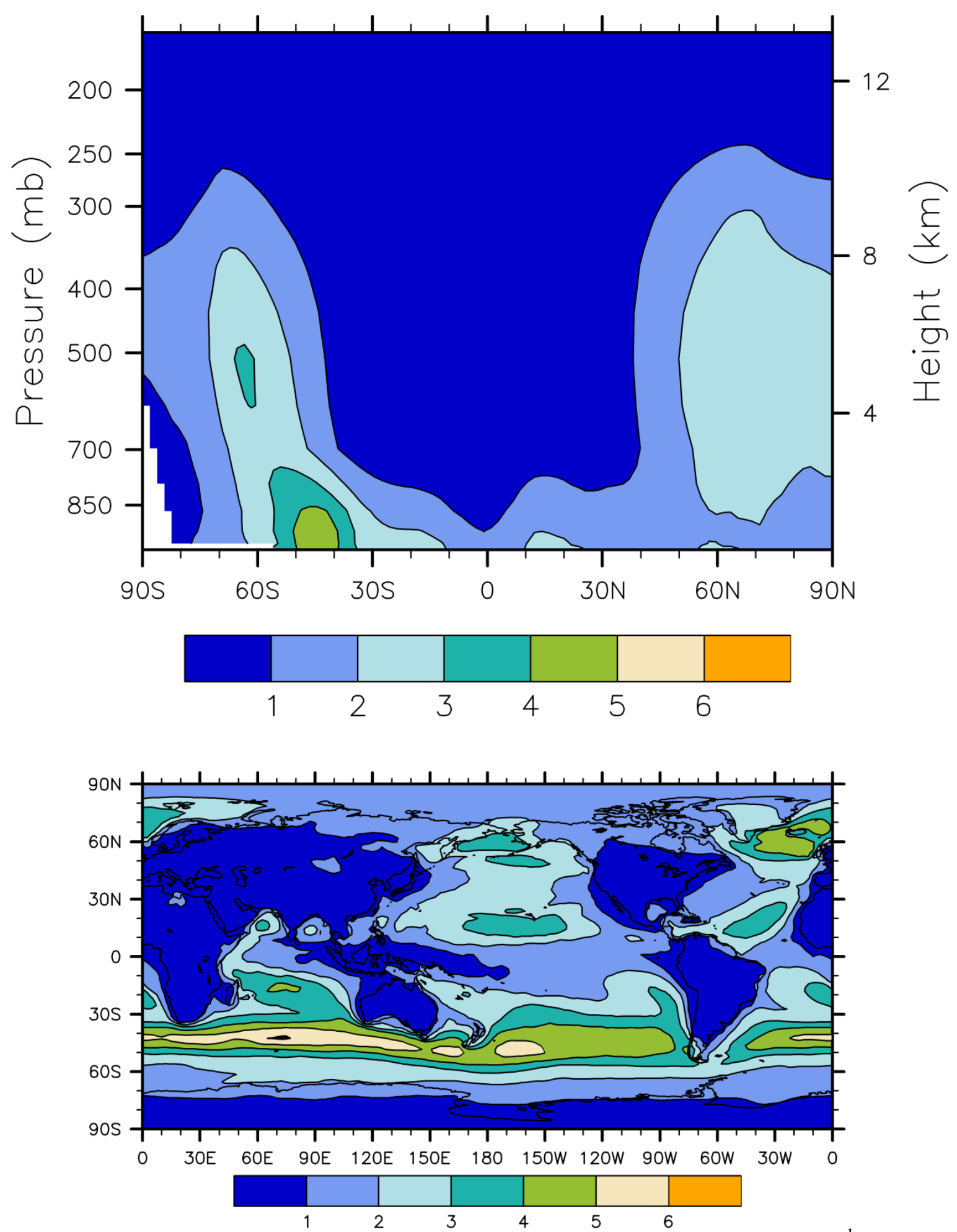

Figure 5. Annual mean a) zonal and b) PBL BrO mixing ratios ( $\mathrm{pmol} \mathrm{mol}^{-1}$ ). 


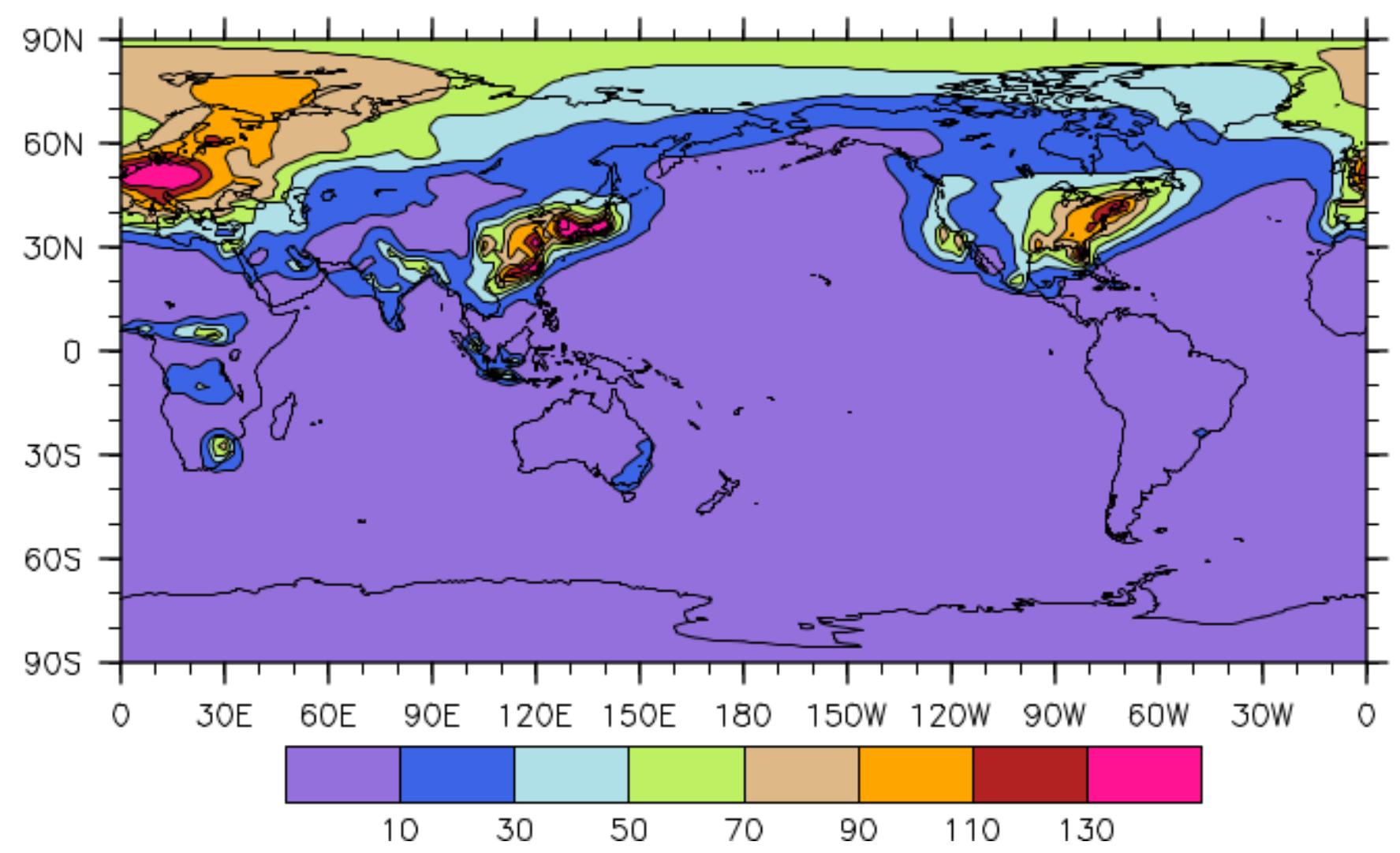

Figure 6. ANN-PBL $\mathrm{ClNO}_{2}$ mixing ratio $\left(\mathrm{pmol} \mathrm{mol}^{-1}\right)$. 


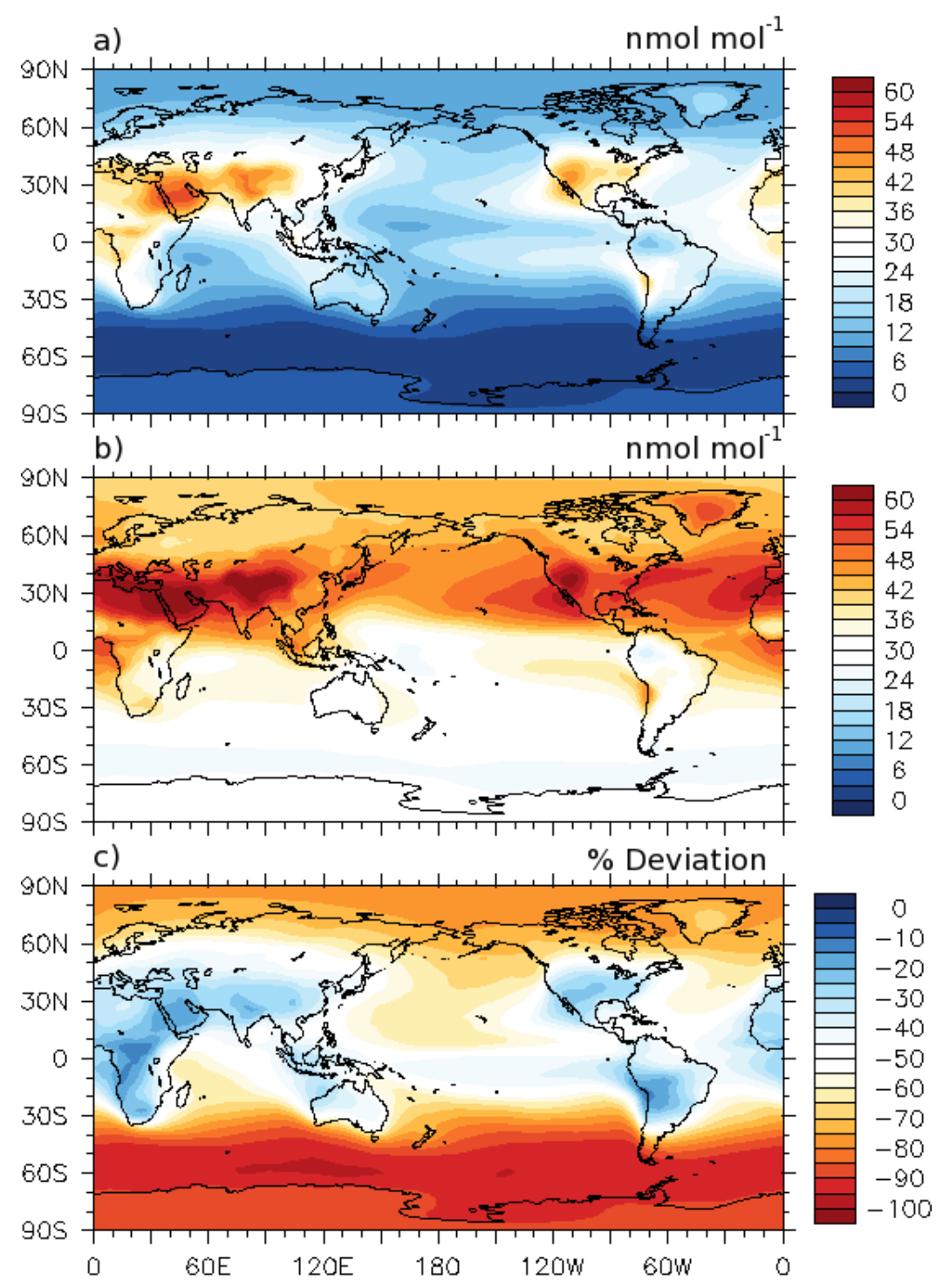

Figure $7 \mathrm{ANN}^{\mathrm{PBL} \mathrm{O}} \mathrm{O}_{3}\left(\mathrm{nmol} \mathrm{mol}{ }^{-1}\right.$ ) for (a) $\mathrm{Hal}$ and (b) NoHal, and (c) the corresponding percent deviations. 


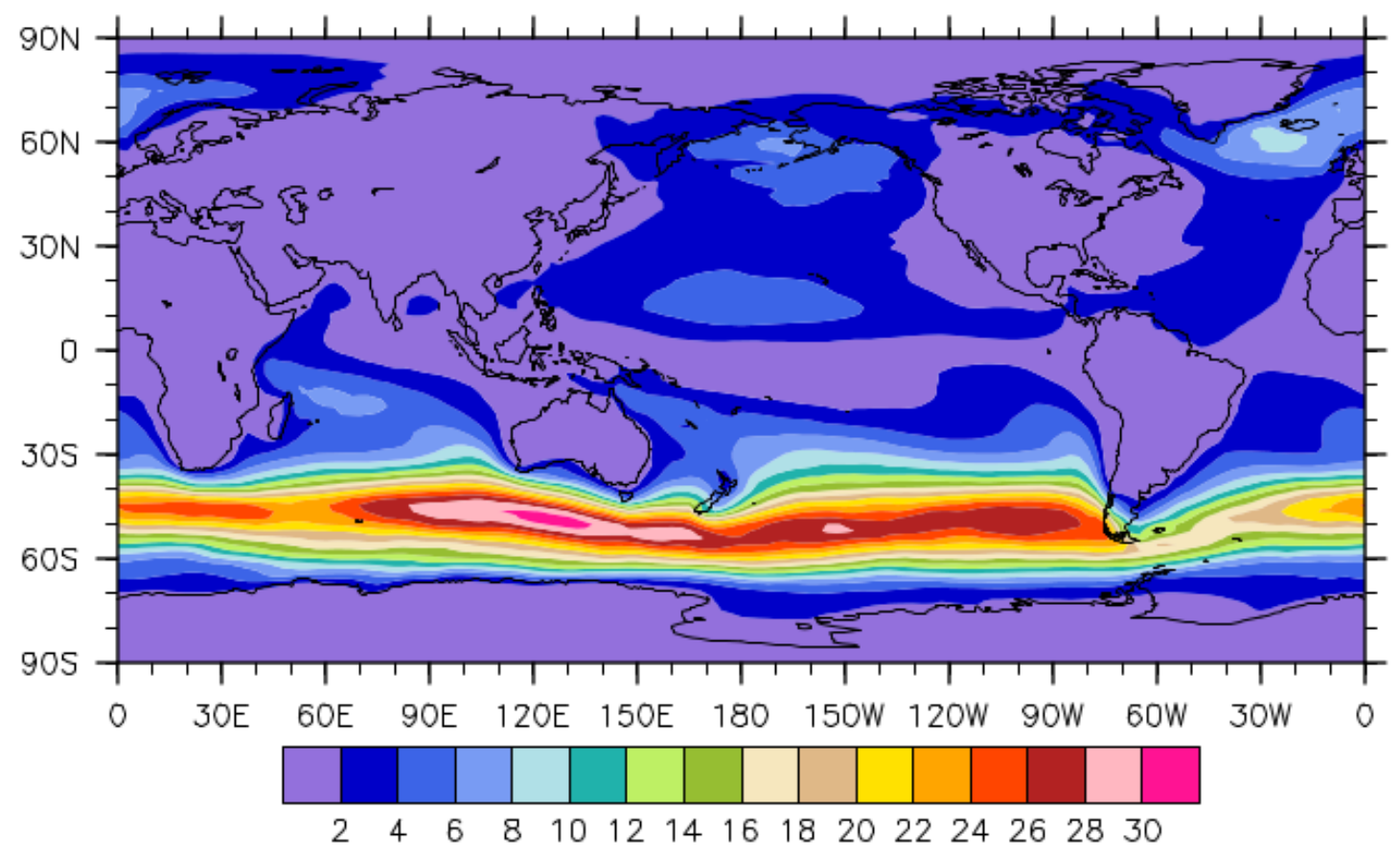

Figure 8. Percent contribution of $\mathrm{Br}+\mathrm{O}_{3}$ to total $\mathrm{O}_{3}$ destruction in PBL (See Table 5). 


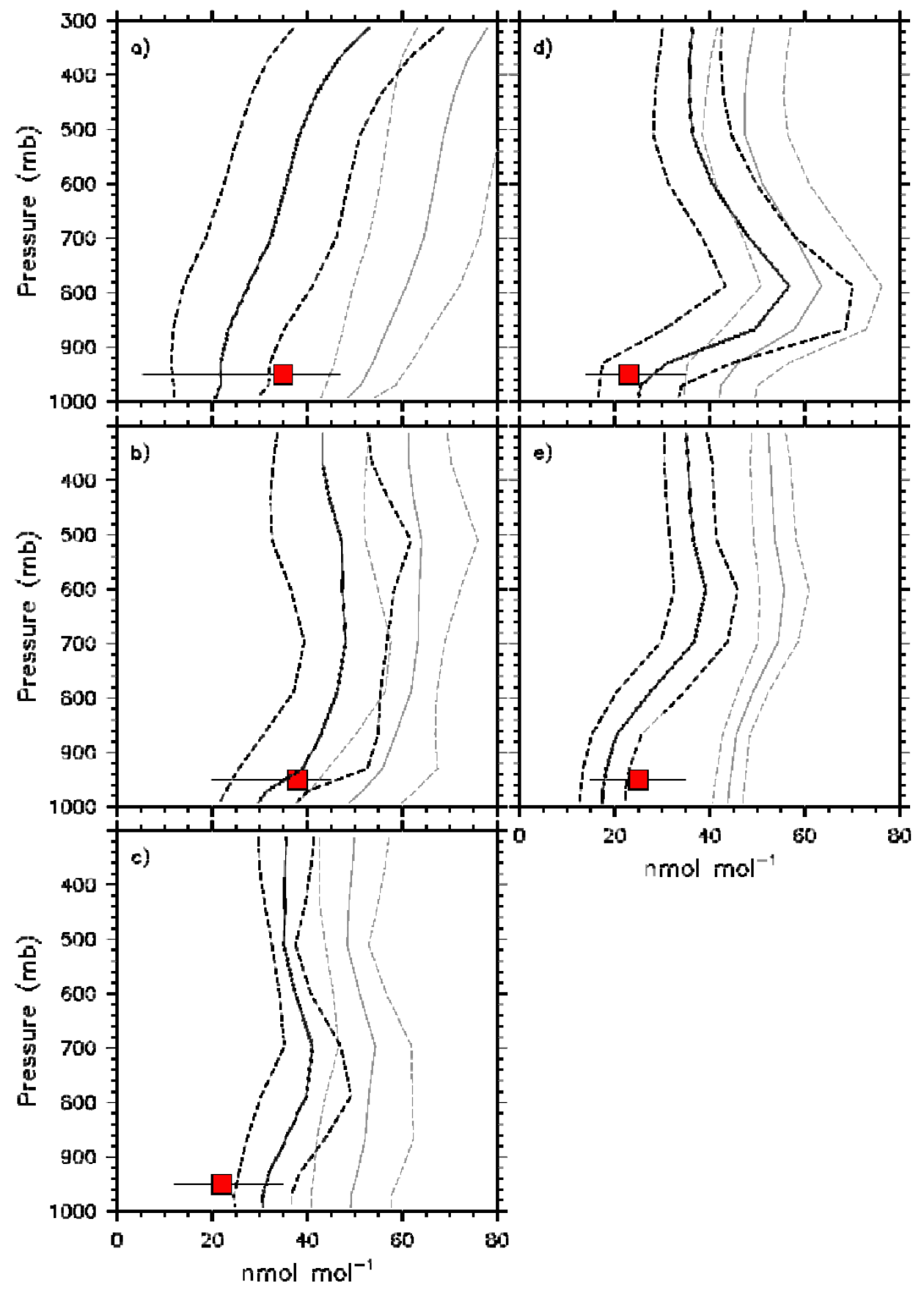

Figure 9. Vertical profiles of mean $\mathrm{O}_{3}\left(\mathrm{nmol} \mathrm{mol}^{-1}\right.$; solid) and standard deviation (dashed) simulated with $\mathrm{Hal}$ (black) and $\mathrm{NoHal}$ (gray) and the corresponding mean $\mathrm{O}_{3}$ measured in near-surface air (red boxes) for the (a) EURO, (b) NAFR, (c) ITCZ, and (d) SATL regimes as reported by Keene et al. (2009) and at (e) Hawaii (Pszenny et al., 2004). Bars depict measurement ranges. 

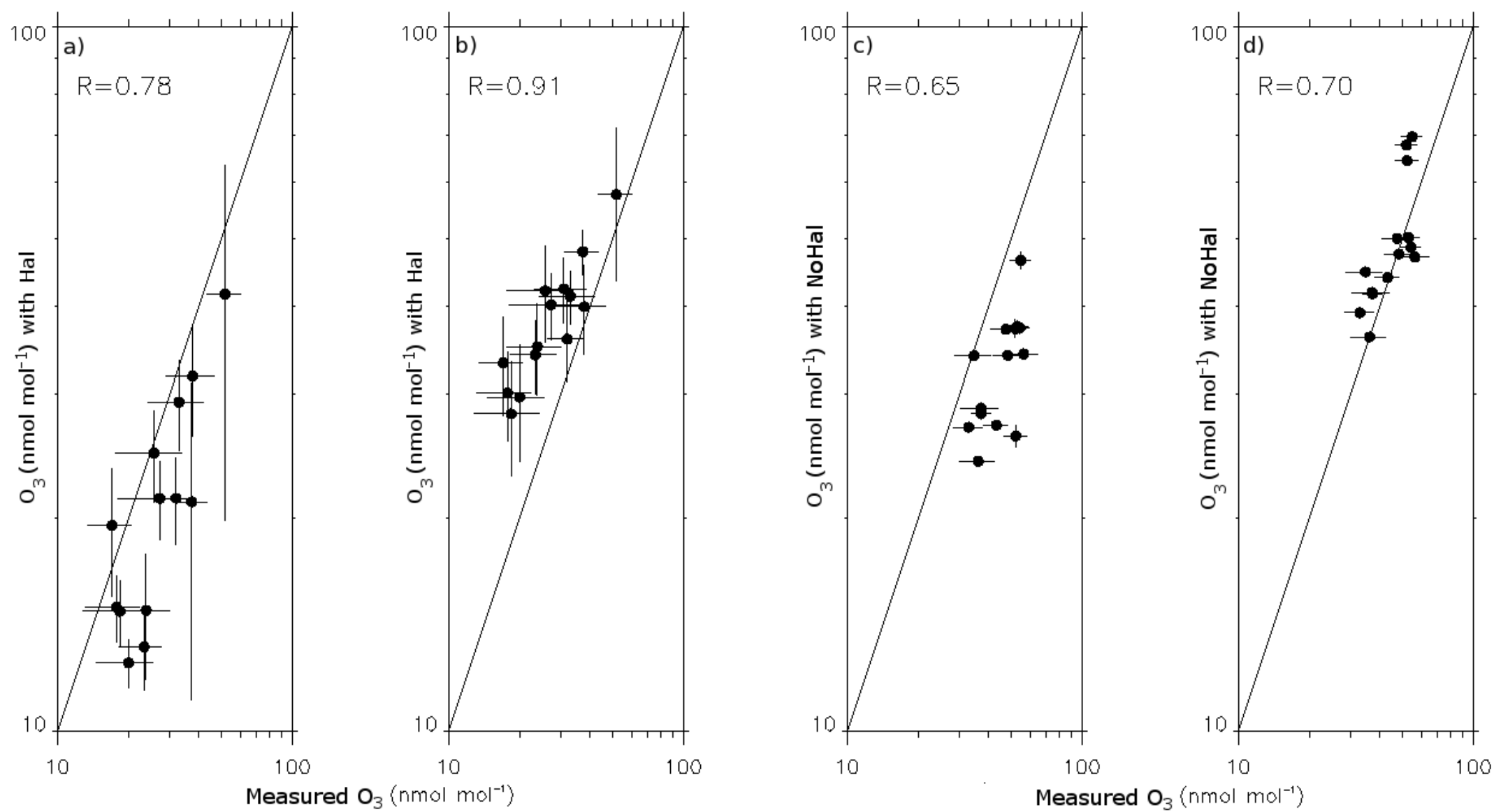

Figure 10. $\mathrm{O}_{3}$ simulated in the PBL with (a) $\mathrm{Hal}$, and(b) $\mathrm{NoHal}$ and at the $500 \mathrm{mb}$ pressure height for (c) $\mathrm{Hal}$ and (d) NoHal versus the WOUDC $\mathrm{O}_{3}$ climatology. Horizontal and vertical bars represent measurement and simulated standard deviations, respectively. The corresponding correlation coefficients (R) are shown. 
a)

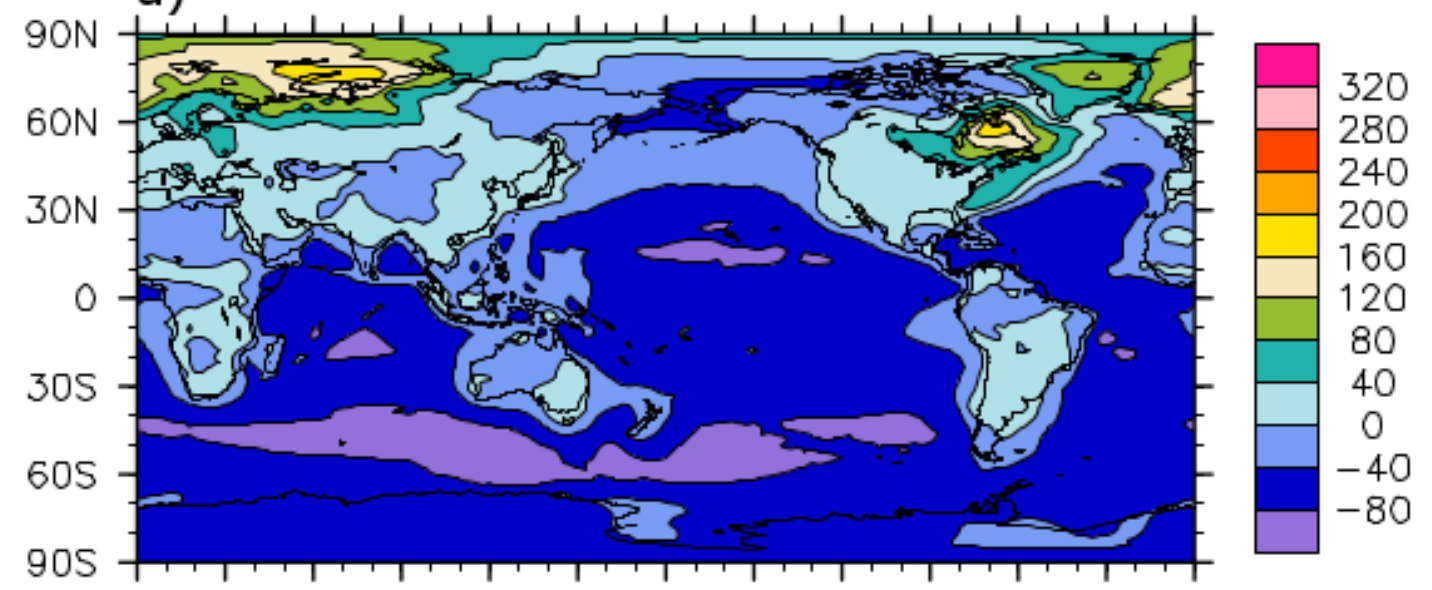

b)

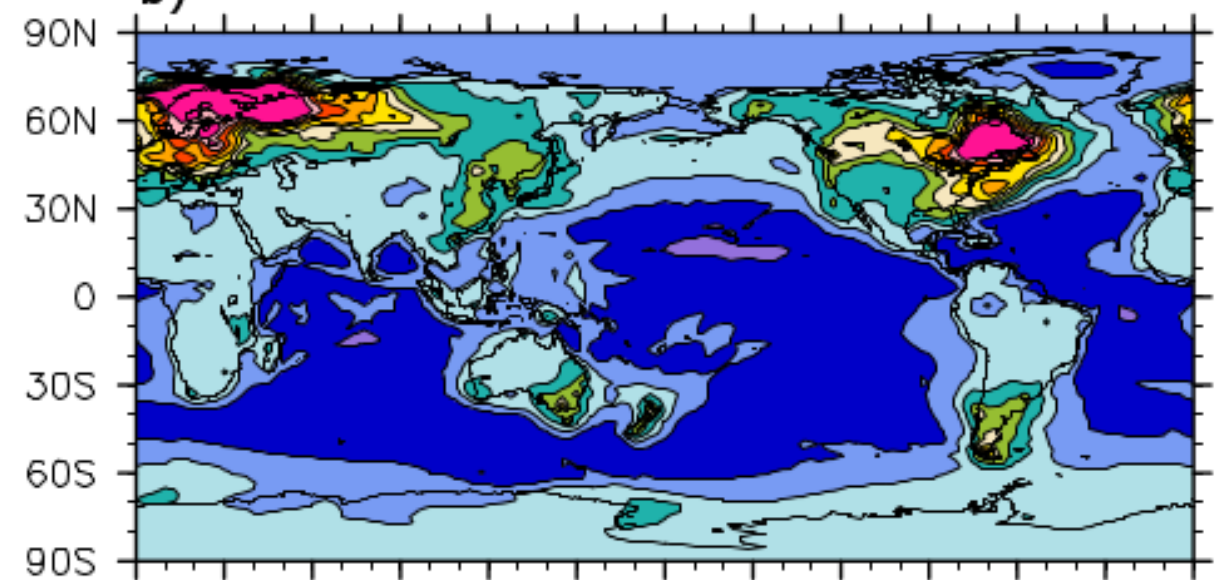

c)

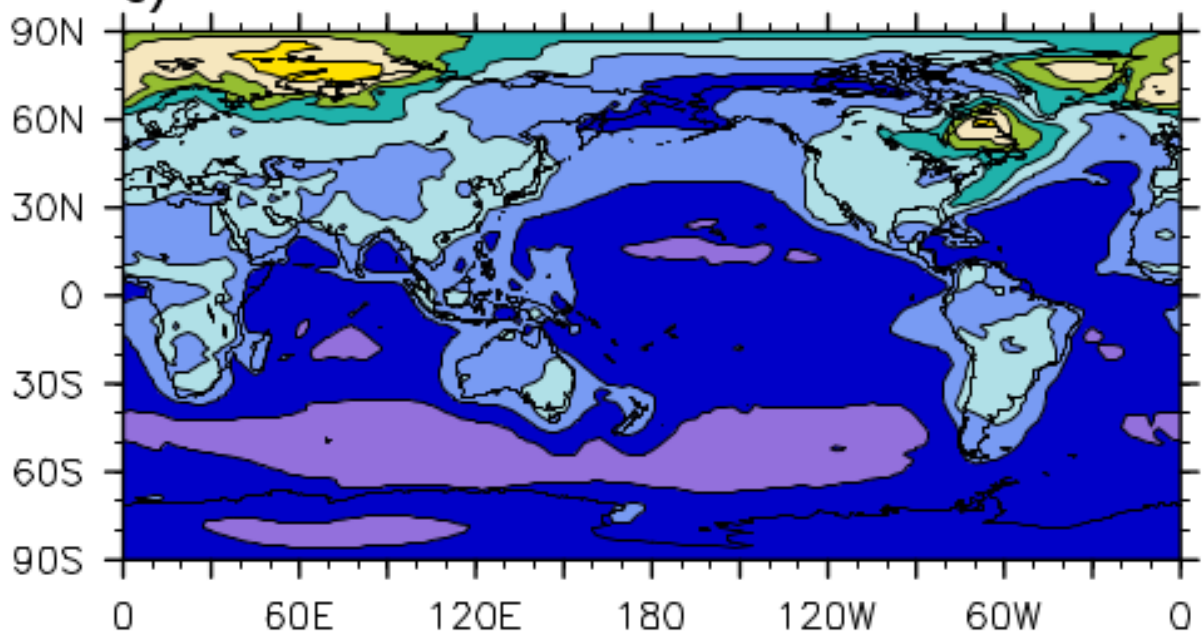

Figure 11. Percent deviation of a) $\mathrm{NO}_{\mathrm{x}}\left(\mathrm{NO}+\mathrm{NO}_{2}\right)$, b) $\mathrm{NO}$, and c) $\mathrm{NO}_{2}$ in the PBL for $\mathrm{Hal}$ versus NoHal simulations. Dashed contour lines indicate negative contour values. 

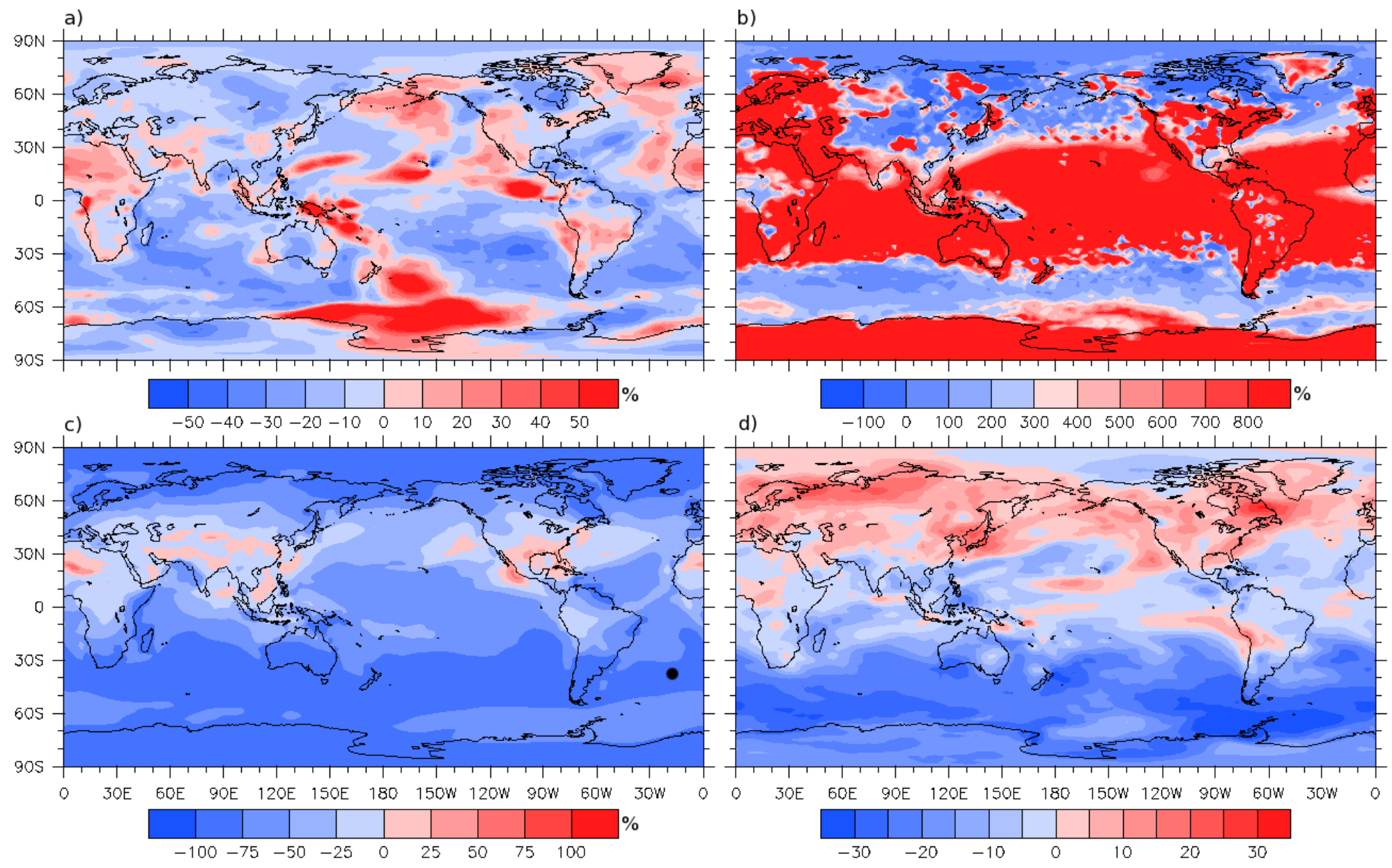

Figure 12. Percent deviations in ANN-PBL (a) $\mathrm{SO}_{2}$, (b) aggregate aqueous $\mathrm{S}(\mathrm{IV})\left(\mathrm{SO}_{2 \text { (aq) }}, \mathrm{HSO}_{3}{ }^{-}\right.$, and $\mathrm{SO}_{3}{ }^{2-}$ summed over the three simulated size bins), (c) DMS and (d) aggregate nss- $-\mathrm{SO}_{4}$. 

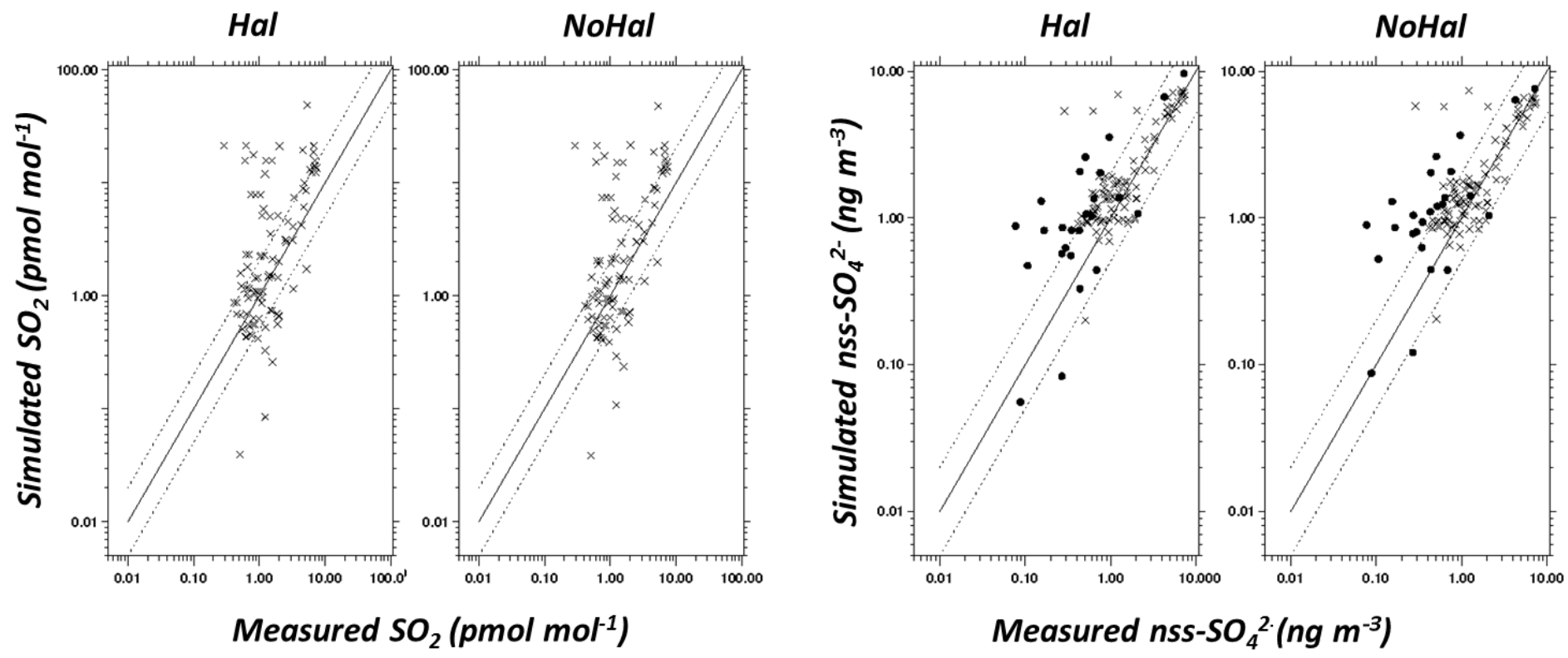

Figure 13. Mean $\mathrm{SO}_{2}$ measured by the IMPROVE network at continental sites in the US versus mean $\mathrm{SO}_{2}$ in the surface layer of the corresponding grid cell simulated with (a) $\mathrm{Hal}$ and (b) $\mathrm{NoHal}$. Mean nss-SO ${ }_{4}{ }^{2-}$ measured at continental sites by the IMPROVE network (designated by x's) and at marine sites by Atmosphere-Ocean Chemistry Experiment (AEROCE, Savoie et al., 2002), U.S. Department of Energy as the Environmental Measurements Laboratory (DOE-EML), and the Sea-Air Exchange Experiment (SEAREX, Riley et al., 1989) (designated by dark circles) versus mean nss-SO ${ }_{4}^{2-}$ in the surface layer of the corresponding grid cells simulated with (c) Hal and (d) NoHal. 